\title{
Geologic Map of \\ Colorado National Monument and Adjacent Areas, Mesa County, Colorado
}

By Robert B. Scott, ${ }^{1}$ Anne E. Harding, ${ }^{1}$ William C. Hood ${ }^{2}$ Rex D. Cole, ${ }^{3}$ Richard F. Livaccari, ${ }^{3}$ James B. Johnson, ${ }^{3}$ Ralph R. Shroba, ${ }^{1}$ and Robert P. Dickerson ${ }^{1}$

Prepared in cooperation with the National Park Service and the Colorado National Monument Association

Pamphlet to accompany

Geologic Investigations Series I-2740

2001

${ }^{1}$ U.S. Geological Survey, Denver, CO 80225

2515 Dove Court, Grand Junction, CO 81503

${ }^{3}$ Department of Physical and Environmental Sciences, Mesa State College, Grand Junction, CO 81502

U.S. Department of the Interior

U.S. Geological Survey 

Description of map units .

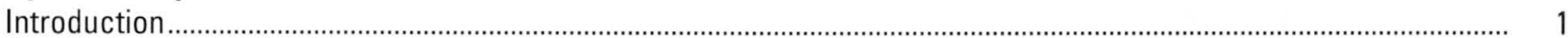

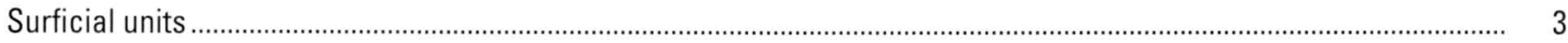

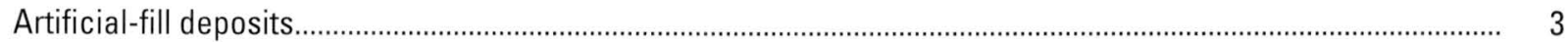

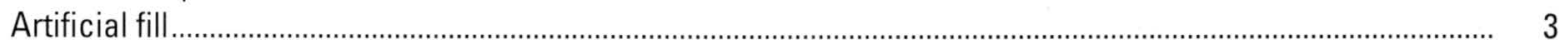

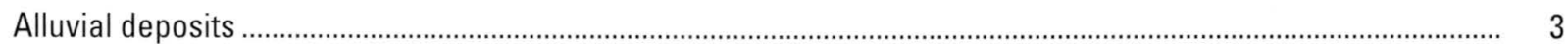

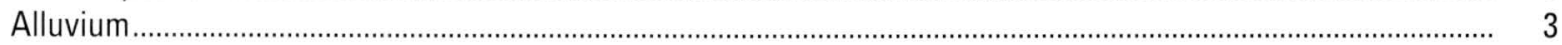

Flood-plain and stream-channel deposits ...................................................................................................... 3

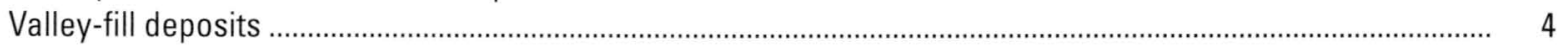

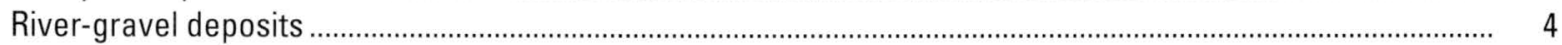

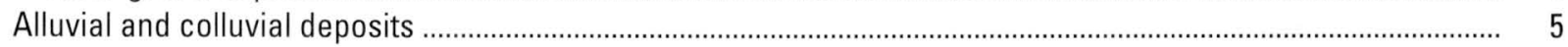

Young fan-alluvium and debris-flow deposits................................................................................................ 5

Younger alluvial-slope deposits ....................................................................................................................... 5

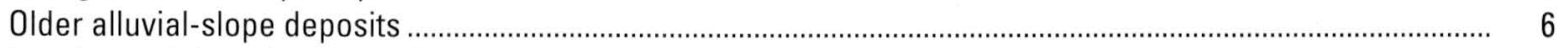

Local gravel deposits ............................................................................................................................. 6

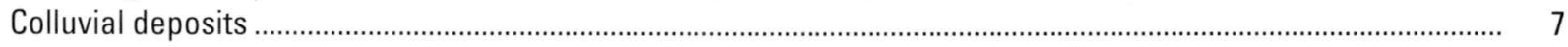

Colluvium, undivided ..................................................................................................................................... 7

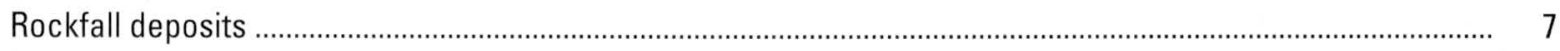

Younger landslide deposits ............................................................................................................................ 8

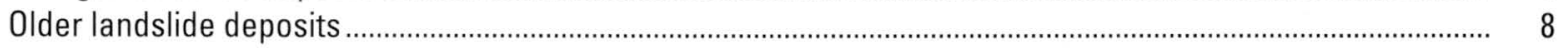

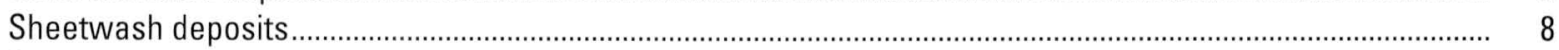

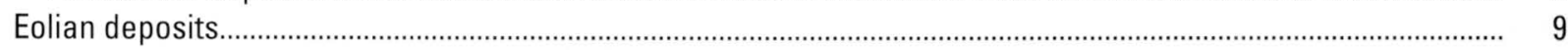

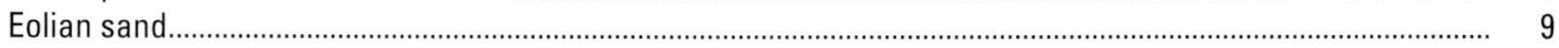

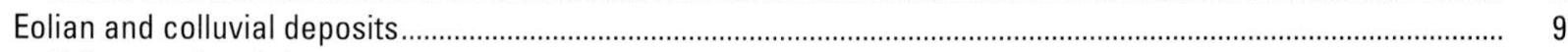

Eolian sand and sheetwash deposits................................................................................................... 9

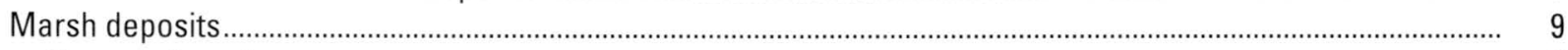

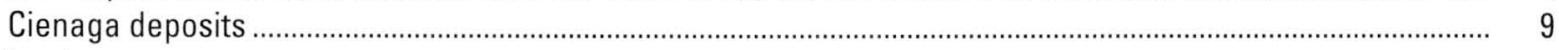

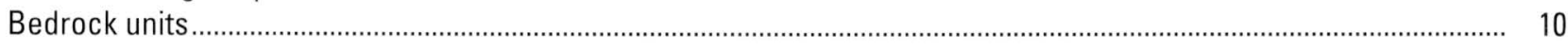

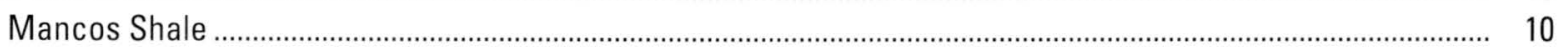

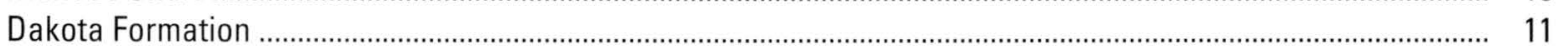

Burro Canyon Formation ....................................................................................................................... 12

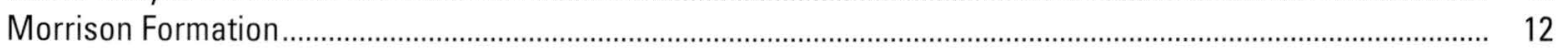

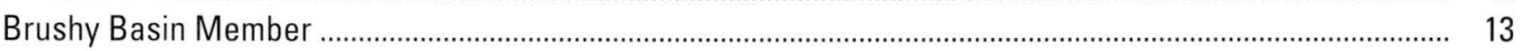

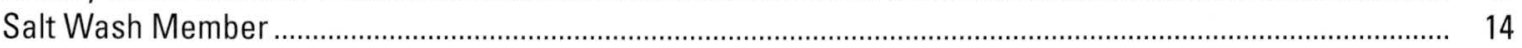

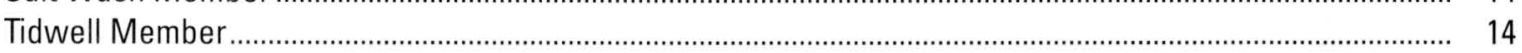

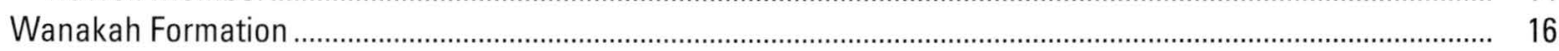

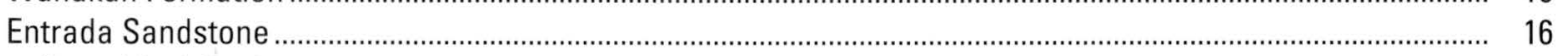

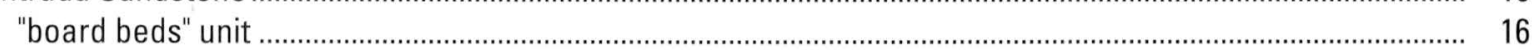

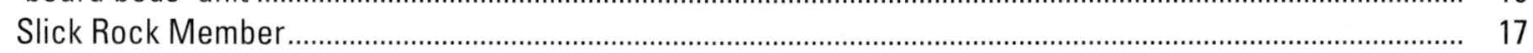

Wanakah Formation and Entrada Sandstone, undivided............................................................................... 17

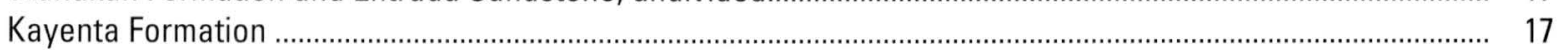

Wanakah Formation and Entrada Sandstone and Kayenta Formation, undivided ............................................. 18

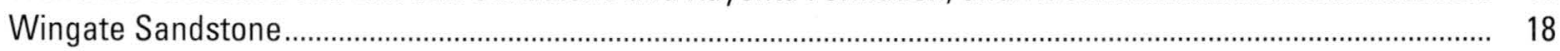

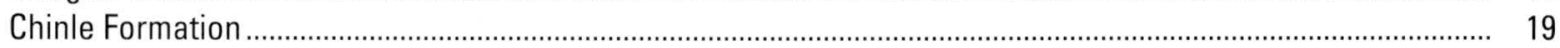

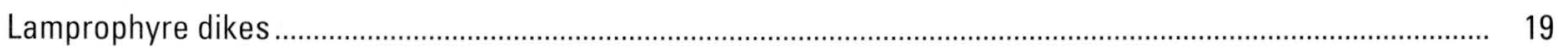

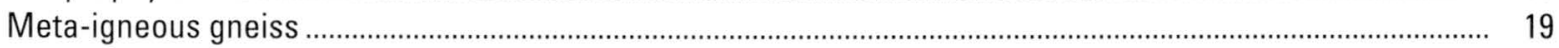

Migmatitic meta-sedimentary rocks ......................................................................................................... 20 
Selected stratigraphic topics.

Alluvial fans 21

Bedrock contacts .................................... 21

Geochronology

Geologic formation of Colorado National Monument

Geologic History

Structural and tectonic issues

Interpretation of structures at Colorado National Monument.

Late Cenozoic regional uplift.

Pliocene arching at Unaweep Canyon

Geologic hazards

Geologic resources

Acknowledgments

References cited.

Glossary

\section{Figures}

Figure 1. Regional geographic features in western Colorado and eastern Utah.

Figure 2. Geographic features near the map area

\section{Tables}

Table 1. Grain sizes in metric and English units

Table 2. Factors for conversion of metric units to English units

Table 3. Definitions of divisions of geologic time.

Table $4 .{ }^{14} \mathrm{C}$ laboratory and calibration ages for sediments 
Description of Map Units

\section{Introduction}

This introduction provides information that makes the DESCRIPTION OF MAP UNITS easier to understand. Explanations are given for ages of surficial deposits. References are provided for publications that explain or define soil horizons, grain sizes, soil colors, bedrock colors, and igneous and sedimentary rock terms. Tables are included that show geologic grain sizes, conversion from metric to English units, and geologic time. Geologic terms used in this text that are not in Webster's New World Dictionary, Third College Edition, are italicized, and brief definitions of these terms are provided in the GLOSSARY at the end of the text.

Age assignments for surficial deposits are based chiefly on the degree of modification of original landform or surface morphology, height above stream level, and degree of soil development. Age assignments for units Qrg (river-gravel deposits) and Qlg (local gravel deposits) are based chiefly on a regional rate of stream downcutting or incision of about $0.14 \mathrm{~m} / \mathrm{ky}$ ( $\mathrm{ky}$, thousand years), a minimum local rate of steam downcutting of about $0.16 \mathrm{~m} / \mathrm{ky}$, and on a local rate of stream downcutting of about $0.14 \mathrm{~m} / \mathrm{ky}$.

The regional incision rate of $0.14 \mathrm{~m} / \mathrm{ky}$ is based on an average of three values for stream incision since deposition of the

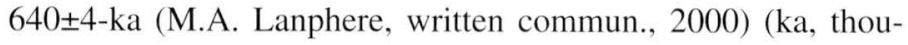
sand years old) Lava Creek B volcanic ash: (1) about $90 \mathrm{~m}$ of incision along the Colorado River near the east end of Glenwood Canyon (Izett and Wilcox, 1982), (2) about $88 \mathrm{~m}$ of incision along the Roaring Fork River near Carbondale, Colorado (Piety, 1981), and (3) about 80-85 $\mathrm{m}$ of incision along the White River near Meeker, Colorado (Whitney and others, 1983; J.W. Whitney, U.S. Geological Survey, oral commun., 1992).

The minimum local rate is based on about $1,600 \mathrm{~m}$ of downcutting by the Colorado River after eruption of the 10-Ma (Ma, million years old) basalt on Grand Mesa (Marvin and others, 1966) near Palisade, Colorado, about $18 \mathrm{~km}$ east of the map area. The reason a minimum rate is proposed at Grand Mesa is because the timing of initial downcutting of Grand Mesa by the Colorado River is unknown.

The local rate of stream downcutting of $0.14 \mathrm{~m} / \mathrm{ky}$ is based on the presence of the Lava Creek B volcanic ash about $91 \mathrm{~m}$ above the drainage at a site on the Harley Dome 7.5-minute quadrangle in Utah (39 $13.52^{\prime}$ Lat., $109^{\circ} 10.44^{\prime}$ Long.) (Willis, 1994). This identification was reconfirmed by major-element analyses by Andrei Sarna-Wocjicki (U.S. Geological Survey, written commun., 2000) and by trace-element analyses by Jim Budahn (U.S. Geological Survey, written commun., 2000). Another ash sample collected by Rex Cole, Bill Hood, and Paul Carrara $1.8 \mathrm{~km}$ east of the Utah border $\left(39^{\circ} 20.166^{\prime}\right.$ Lat., $109^{\circ}$ 01.770' Long.) on the Bar X 7.5-minute quadrangle could not be positively identified as Lava Creek B ash because of alteration. This ash is also about $91 \mathrm{~m}$ above the local drainage.

Sand, gravel, and other surficial deposits shown on the map are estimated to be at least $1 \mathrm{~m}$ thick. Where surficial deposits are thin or discontinuous they were not mapped. Soil-horizon designations are those of the Soil Survey Staff (1975), Guthrie and Witty (1982), and Birkeland (1999). Most of the surficial deposits are calcareous and contain variable amounts of primary and secondary calcium carbonate; stages of secondary calcium carbonate morphology (referred to as stages I through III horizons in this report) are those of Gile and others (1966). Grain sizes given for surficial deposits and bedrock are based on field estimates and follow the modified Wentworth (1922) scale (American Geological Institute, 1982) (Table 1). In descriptions of surficial map units, the term "clasts" refers to the fraction greater than $2 \mathrm{~mm}$ in diameter, whereas the term "matrix" refers to the particles less than $2 \mathrm{~mm}$ in size. Dry matrix colors of the surficial deposits were determined by comparison with Munsell Soil Color Charts (Munsell Color, 1973). Colors of the surficial deposits correspond to those of the sediments and (or) bedrock from which they were derived.

Bedrock colors were determined by comparison with the Geological Society of America Rock-Color Chart (Rock-Color Chart Committee, 1951). Igneous rock terms follow that of the IUGS classification (Streckeisen, 1973). Sedimentary bedrock terms follow the classifications of Folk (1974) for sandstone and conglomerate, Dunham (1962) for carbonate rocks, and Picard (1971) for mudstone (we use "mudstone" in place of Picard's term "mudrock"). Bedding thickness terms follow those of Ingram (1954) and Potter and others (1980). Degree of sorting terms follow those of Pettijohn and others (1973) and Folk (1974). Grain shape terms follow those of Powers (1953). Sedimentary structure terms follow those of McKee and Weir (1953), Campbell (1967), Allen (1970), and Boggs (1995). Fossil and trace fossil terms follow those of Ekdale and others (1984) and Pemberton and others (1992).

Metric units are used in this report; a conversion table is provided for those more familiar with English units (Table 2). A review of the divisions of geologic time used in this report is also provided (Table 3 ).

Table 1. Grain sizes in metric and English units (American Geological Institute, 1982).

\begin{tabular}{lll}
\hline Clay & less than $0.004 \mathrm{~mm}$ & less than 0.00016 inches \\
Silt & 0.004 to $0.062 \mathrm{~mm}$ & 0.00016 to 0.0025 inches \\
Sand & 0.062 to $2 \mathrm{~mm}$ & 0.0025 to 0.08 inches \\
Granule & 2 to $4 \mathrm{~mm}$ & 0.08 to 0.16 inches \\
Pebble & 4 to $64 \mathrm{~mm}$ & 0.16 to 2.5 inches \\
Cobble & 64 to $256 \mathrm{~mm}$ & 2.5 to 10 inches \\
Boulder & greater than $256 \mathrm{~mm}$ & greater than 10 inches \\
\hline
\end{tabular}

Table 2. Factors for conversion of metric units to English units to two significant figures.

\begin{tabular}{lll} 
Multiply & By & To obtain \\
\hline centimeters $(\mathrm{cm})$ & 0.39 & inches \\
meters $(\mathrm{m})$ & 3.3 & feet \\
kilometers $(\mathrm{km})$ & 0.62 & miles \\
\hline
\end{tabular}


Table 3. Definitions of divisions of geologic time used in this report.

\begin{tabular}{|c|c|c|c|c|}
\hline \multirow[t]{6}{*}{ EON } & ERA & Period & ${\text { Epoch } / \mathbf{A g e}^{2}}^{2}$ & Years \\
\hline & \multirow{3}{*}{ CENOZOIC } & & Holocene & 0 to 10 thousand \\
\hline & & Quaternary & & \\
\hline & & Tertiary & Pleistocene & 10 thousand to 1.65 million \\
\hline & & Cretaceous & & \\
\hline & \multirow{17}{*}{ MESOZOIC } & & Late Cretaceous & 66.4 to 97.5 million \\
\hline \multirow[t]{20}{*}{ PHANEROZOIC- } & & & Turonian & 88.5 to 91 million \\
\hline & & & Cenomanian & 91 to 97.5 million \\
\hline & & & Early Cretaceous & 97.5 to 144 million \\
\hline & & & Albian & 97.5 to 113 million \\
\hline & & & Aptian & 113 to 119 million \\
\hline & & Jurassic & & \\
\hline & & & Late Jurassic & 163 to 144 million \\
\hline & & & Tithonian & 144 to 152 million \\
\hline & & & Kimmeridgian & 152 to 156 million \\
\hline & & & Oxfordian & 156 to 163 million \\
\hline & & & Middle Jurassic & 163 to 187 million \\
\hline & & & Callovian & 163 to 169 million \\
\hline & & & Lower Jurassic & 187 to 208 million \\
\hline & & & Pliensbachian & 193 to 198 million \\
\hline & & & Sinemurian & 198 to 204 million \\
\hline & & & Hettangian & 204 to 208 million \\
\hline & & Triassic & & \\
\hline & & & Late Triassic & 208 to 230 million \\
\hline & & & Norian & 208 to 225 million \\
\hline & & & Carnian & 225 to 230 million \\
\hline PROTEROZOIC & \multicolumn{2}{|c|}{ EARLY PROTEROZOIC } & & 1,600 to 2,500 million \\
\hline
\end{tabular}

After Hansen (1991) except for the Pleistocene.

${ }^{1}$ Subdivisions of Pleistocene time are informal and are as follows: late Pleistocene is 10-132 thousand years, middle Pleistocene is 132-788 thousand years, and early Pleistocene is 788-1,650 thousand years (Richmond and Fullerton, 1986). Subdivisions of the Cretaceous, Jurassic, and Triassic follow those of Geological Society of America (1999).

${ }^{2}$ Subdivisions of epochs are Ages, the smallest division of geologic time; Ages are shown in bold. These small subdivisions of time are most commonly used by paleontologists and stratigraphers.

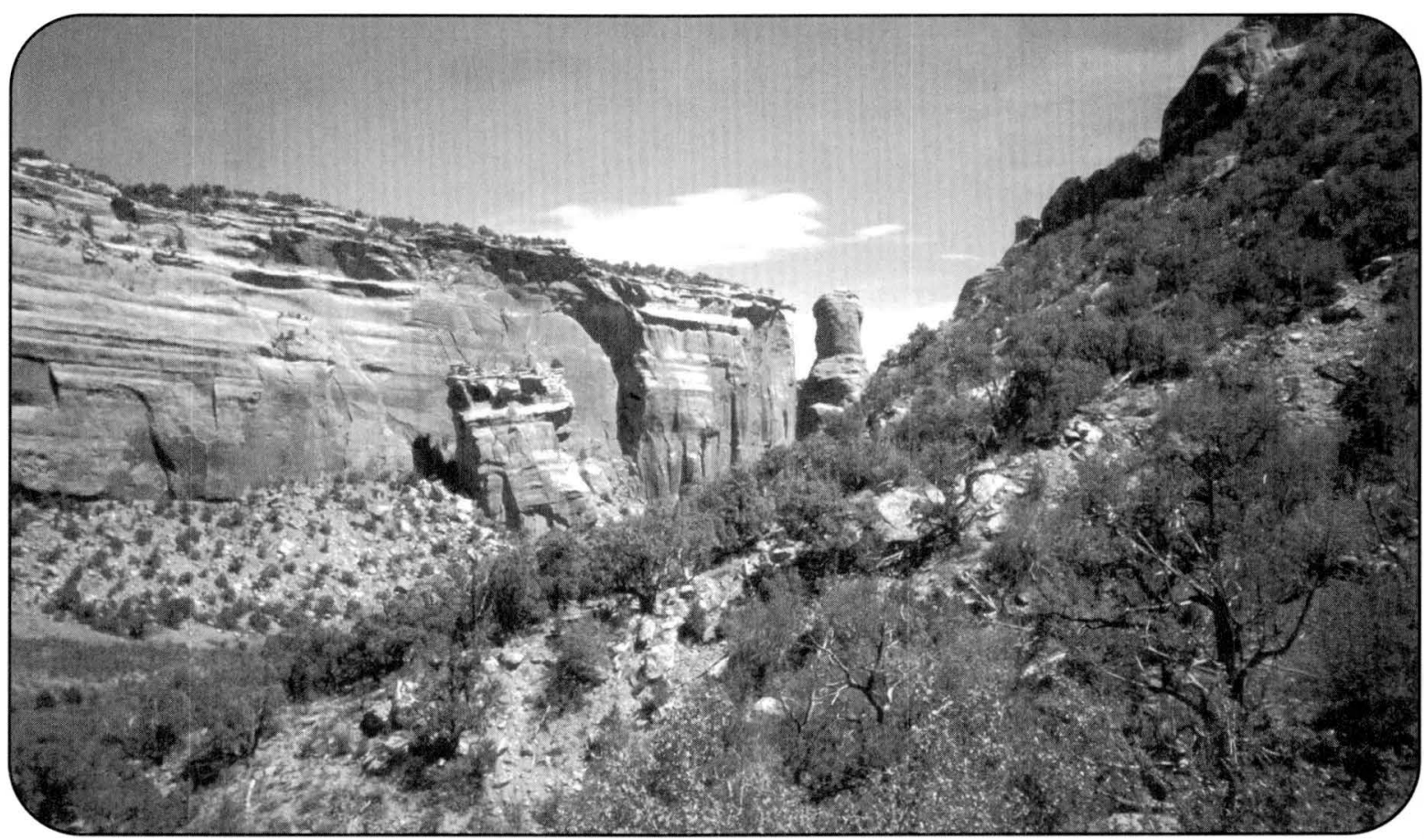

Fallen rock, as viewed part way down the Ute Canyon Trail. View to the east. Photograph by R.B. Scott, 1998. 


\section{Surficial Units}

To make the descriptions of surficial units easier for the non-geologist to read, the first paragraph of each description provides a summary statement. More detailed technical information follows.

Artificial-fill Deposits-Artificial-fill deposits include compacted and uncompacted material composed mostly of silt, sand, and rock fragments placed beneath and adjacent to highways, an airstrip, stock ponds, and earthen dams.

Artificial fill (latest Holocene)-Most of the artificial fill consists of compacted and uncompacted fill material composed of silt, sand, and rock fragments. The map unit was mapped beneath segments of the Interstate 70 overpass at the junction with U.S. Highway 6-50 and beneath segments of Rim Rock Drive, the road that follows the canyon rims in Colorado National Monument, particularly where road reconstruction required fill after the flash flood of 1968 in Fruita Canyon.

Small amounts of fill beneath the nearby tracks of the Denver and Rio Grande Western Railroad were not mapped. Artificial fill was also used in constructing the reservoir in lower Fruita Canyon and in many minor dams for stock ponds on private land. A dirt airstrip near the southern border of the map area is underlain in part by artificial fill. Generally the map unit is less than $10 \mathrm{~m}$ thick, but beneath Rim Rock Drive, artificial fill is locally greater than $50 \mathrm{~m}$ thick.

Alluvial Deposits-Alluvial deposits include silt, sand, and gravel in flood plains, stream channels, and terraces along the Colorado River and its tributaries.

Qal

Alluvium (Holocene)-Alluvium consists chiefly of stream-channel deposits along streams that are tributaries of the Colorado River.

The map unit includes minor undifferentiated colluvial deposits such as young fan-alluvium and debris-flow deposits (Qfy), debris-flow deposits (not shown as a separate map unit), and sheetwash deposits (Qsw). Locally, the unit includes boulders as large as $2 \mathrm{~m}$ in diameter. Unit Qal typically consists of interbedded sand, pebbly sand, and pebble gravel and ranges from thin-bedded $(0.1$ to $0.5 \mathrm{~cm})$ clayey, silty sand to thick-bedded $(>1 \mathrm{~m})$, poorly sorted, both clastand matrix-supported, slightly bouldery, pebble and cobble gravel with a sand matrix. Little or no secondary carbonate is present.

Low-lying areas of the map unit are prone to periodic flooding and debris-flow deposition, particularly during and after major thunderstorms.
Associated flash floods pose a serious hazard in narrow, restricted canyons of Colorado National Monument. Significant potential for flash flood and debris-flow hazards also exists in and near stream channels between the highlands of the Monument and the Colorado River. The exposed thickness of alluvium is about 1 to $4 \mathrm{~m}$.

Flood-plain and stream-channel deposits (Holocene and late Pleistocene)-Most of the flood-plain and stream-channel deposits consist of clast-supported, slightly bouldery, pebble and cobble gravel in a sand matrix deposited along the Colorado River.

The unit contains lenses of gravelly sand to sandy silt. A thin upper part is locally present and consists of gravelly sand or sandy silt. In the lower part, clasts are generally less than $40 \mathrm{~cm}$ in diameter, subrounded to well rounded, and poorly to moderately well sorted. Clasts were derived from bedrock units upstream along the Colorado River and its tributaries. The unit contains an assortment of clasts of Cenozoic, Mesozoic, and Paleozoic sedimentary rocks, which include the yellowishgray- (5Y7/2) weathering "oil shale" of the Green River Formation and moderate-red (5R5/4) Maroon Formation. The clasts also include igneous rocks of several ages, which include granitic rocks as well as rhyolitic and basaltic volcanic rocks, numerous Proterozoic metamorphic rocks, and minor hornfels from contact metamorphism of the Morrison Formation. Sediments exposed in gravel pits (boundaries of pits are delineated by dashed lines) locally display scour-and-fill structure. Elongate clasts are inclined upstream forming an overlapping imbricate structure.

Unit Qfp is in low-lying areas and is subject to flooding, particularly during spring runoff from snow melt in mountainous areas upstream along the Colorado River and its tributaries. Gravel is an important resource that is becoming increasingly scarce in and near the map area. Drill-hole data for the area north of the Colorado River indicate that 3 to $15 \mathrm{~m}$ of sheetwash deposits (Qsw) overlie 3 to $7 \mathrm{~m}$ of Colorado River gravel in unit Qfp, which in turn overlies Mancos Shale (Km) (Ken Weston; U.S. Bureau of Reclamation, written commun., 1999; Phillips, 1986). These data, however, may not represent the entire thickness of unit Qfp, because it is difficult to distinguish in drilling records between sheetwash deposits (Qsw) and lenses of sandy silt in the upper part of unit Qfp. The thickness of unit Qfp locally may exceed $7 \mathrm{~m}$. 

many canyons of the Monument consist chiefly of sand and silt of stream-terrace alluvium and probably sandy debris-flow deposits, but also locally include stony colluvium on valley sides as well as minor deposits of eolian sand (Qe) and sheetwash (Qsw).

The valley-fill deposits can be subdivided into a thicker bedded ( $>30 \mathrm{~cm}$ ), slightly calcareous, upper part and a thinner bedded $(<30 \mathrm{~cm})$, calcar * eous, lower part. Both parts consist mostly of sand and silt that contain small, discontinuous lenses of gravel. Cobbles are as large as $25 \mathrm{~cm}$ in diameter. Both parts locally contain several buried, weakly developed paleosols and common small $(<2 \mathrm{~mm})$ charcoal fragments. Some of these paleosols are darker than the rest of unit Qvf because of the accumulation of organic matter; they contain abundant charcoal, presumably from burnt woody vegetation. Charcoal not associated with paleosols is concentrated at bedding breaks in the sediments, but charcoal also occurs within beds. The age of the valley-fill deposits, based on calibrated ${ }^{I 4} \mathrm{C}$ ages (Table 4), ranges from at least 1,180 to 6,200 years BP (before present, actually before 1954) in the upper part to at least as old as 10,360 years BP in the lower part (Scott, Hood, and others, 1999). The discovery in No Thoroughfare Canyon of a mastodon tooth, which was probably eroded from the undated lowest part of the unit, is consistent with a late Pleistocene age for the lower part of the map unit (for more information, see the text under SELECTED STRATIGRAPHIC TOPICS and GEOCHRONOLOGY).

The upper part of unit Qvf has beds that range typically from 0.1 to $2 \mathrm{~m}$ thick, is generally reddish brown (5YR5/4) to yellowish red (5YR5/8), contains minor charcoal fragments, and has a 0.5 m-thick surface soil. The upper part is weakly indurated by calcium carbonate. In the upper part, gravel lenses range from 0.1 to $0.7 \mathrm{~m}$ thick. Clasts consist of angular to subangular sandstone and minor sedimentary quartzite that range in size from $2-\mathrm{mm}$ granules to $25-\mathrm{cm}$ cobbles. They are coated with secondary calcium carbonate.

The lower part typically has beds 5 to $50 \mathrm{~cm}$ thick, is yellow $(2.5 \mathrm{Y} 7 / 6)$ to reddish yellow (7.5YR 6/6) and locally light olive brown (2.5Y5/ 4 ), has iron oxide staining, and contains more charcoal fragments and fewer gravel lenses than the upper part. The lower part is weakly indurated, due in part to secondary calcium carbonate in a stage II horizon. Thin beds of fine sand and silt in the lower part are slightly wavy and can be traced for more than $40 \mathrm{~m}$ along some exposures. The

\section{Qrg}

gravel lenses in the lower part can be traced only a few meters at most, are about 2 to $5 \mathrm{~cm}$ thick, and consist chiefly of small granules and pebbles.

Valley-fill deposits are best exposed in terrace scarps in the upper part of No Thoroughfare Canyon, but isolated remnants of the unit Qvf are widespread in most canyons throughout the Monument. The upper part is as thick as about $10 \mathrm{~m}$, but it is thinner where it overlies bedrock near canyon walls. The top of the lower part of unit Qvf is commonly $10 \mathrm{~m}$ below the top of the unit, and the lower part of unit Qvf is commonly less than $10 \mathrm{~m}$ thick. Unit Qvf is locally as much as $30 \mathrm{~m}$ thick.

River-gravel deposits (late? and middle Pleistocene)-River-gravel deposits are chiefly clastsupported, bouldery, cobble and pebble gravel in a sand matrix left as isolated remnants on hilltops on the south side of the Colorado River.

The clasts are generally less than $50 \mathrm{~cm}$ in diameter, subrounded to well rounded, and poorly to moderately sorted. Gravel and lenses of gravelly sand to sandy silt are exposed in gravel pits. These pits also reveal scour-and-fill structures as well as an imbricate clast fabric that is consistent with the westward flow direction of the Colorado River. Clasts include the diagnostic moderate-red Maroon Formation and the yellowish-gray Green River Formation among other rock types typical of those transported by the Colorado River that are listed in the description for unit Qfp. Secondary calcium carbonate coatings on clasts have stage III morphology.

Unit Qrg caps hills on the south side of the Colorado River and locally underlies unit Qaso. The tops of the river-gravel deposits are about 15, 35, 65,75 , and $110 \mathrm{~m}$ above the Colorado River. The heights of these deposits suggest that unit Qrg is equivalent in age to late and middle Pleistocene terrace alluvium (units Qty, Qto, and Qtt) outside the map area farther upstream along the Colorado River near Rifle and New Castle, Colorado (Shroba and Scott, 1997; Scott and Shroba, 1997). The presence of deposits of unit Qrg on or near the north-dipping Dakota Formation (Kd) suggests that as the Colorado River cut downward, it migrated northward, eroding the less resistant Mancos Shale $(\mathrm{Km})$ rather than the more resistant underlying Dakota Formation (Kd). The lowest gravel is about $15 \mathrm{~m}$ above the Colorado River in a terrace mantled by unit Qaso. It is as much as $3 \mathrm{~m}$ thick and it can be traced in poor exposures in gullies in the Redlands area where it thins to about 1 to $2 \mathrm{~m}$ thick (indicated on the map by a single dashed line). The thickness of unit Qrg is 1 to $4 \mathrm{~m}$. 


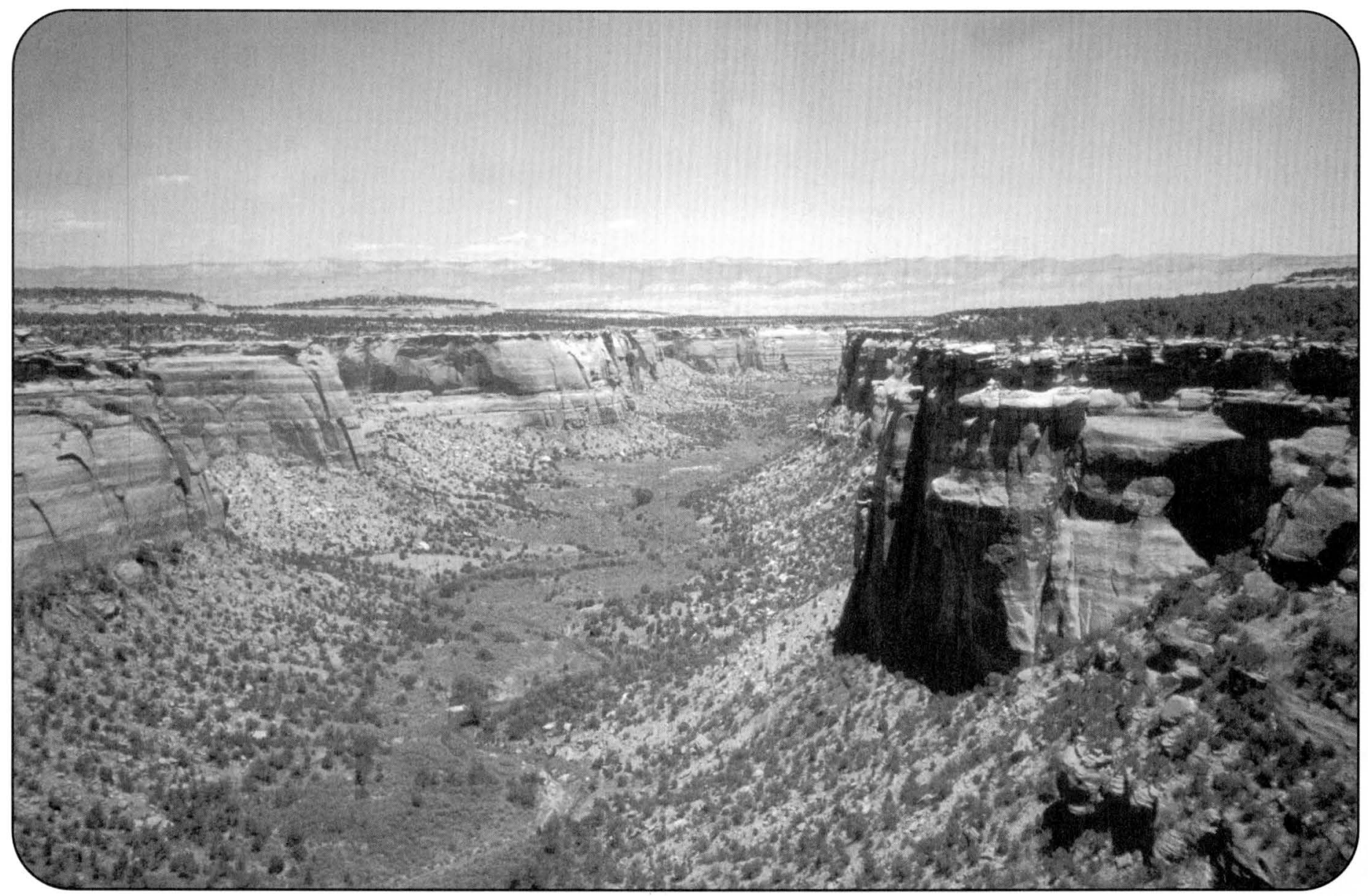

Ute Canyon, view to the northeast. The canyon is floored by the resistant Proterozoic migmatitic meta-sedimentary rocks. The top of the cliffs have remnants of rocks younger than the Kayenta Formation. Photograph by R.B. Scott, 1998.

Alluvial and Colluvial Deposits-Alluvial and colluvial deposits are mostly silt, sand, and gravel in fans on flood plains, in alluvial-slope deposits on river gravel and bedrock, in remnants of tributary stream alluvium and debris-flow deposits, and in deposits of pebbly silty sand that locally mantle canyon bottoms.

\section{Ofy Young fan-alluvium and debris-flow deposits} (Holocene)_Y Young fan-alluvium and debrisflow deposits consist chiefly of well-sorted silty sand and subordinate, discontinuous lenses and layers of clast-supported gravel present on the south side of the Colorado River.

Beds of silty sand are chiefly massive (>1 m thick), but are locally present in beds as thin as 1.5 $\mathrm{cm}$. Some of the silty sand may have been deposited as eolian sand, but much of it is probably reworked by water. Gravel layers are commonly 5 to $45 \mathrm{~cm}$ thick. Unit Qfy consists of material reworked from unit Qaso, silty eolian sand, and, locally, Colorado River gravel reworked from unit Qrg. Gravel clasts range from 2-mm granules to boulders greater than $1 \mathrm{~m}$ in diameter near active stream channels. These clasts are rounded to subrounded, moderately to poorly sorted, and were derived mostly from Proterozoic and Mesozoic units exposed in the highlands to the south in the Uncompahgre Plateau. The gravel was probably deposited by streams and locally by debris flows. Colors of the unit, where silty sand dominates, range from yellowish red (5YR5/8) to reddish yellow (5YR6/6). The gravel lends a gray color to the unit. There is little or no secondary carbonate on clasts and in the matrix.

Unit Qfy forms a few small fans on flood-plain and stream-channel deposits (Qfp) along the south bank of the Colorado River. The base of unit Qfy is as low as $1.5 \mathrm{~m}$ above the river. The exposed thickness is about 1 to $4 \mathrm{~m}$, and the maximum thickness is about $20 \mathrm{~m}$.

Qasy Younger alluvial-slope deposits (late Pleistocene)Younger alluvial-slope deposits consist chiefly of well-sorted silty sand and subordinate, discontinuous lenses and layers of clast-supported gravel and are found along the south side of the Colorado River.

Silty sand ranges commonly from 20 to $80 \mathrm{~cm}$ thick, but locally forms beds as thin as $1 \mathrm{~cm}$ that probably represent eolian material that was 
reworked by water. Gravel layers are commonly 3 to $70 \mathrm{~cm}$ thick. Unit Qasy consists of material reworked from unit Qaso as well as primary and reworked silty eolian sand. Gravel clasts range from granules to boulders larger than $1 \mathrm{~m}$ in diameter near active stream channels. These clasts are poorly sorted and subrounded and were derived mostly from Proterozoic and Mesozoic units exposed in the highlands to the south in the Uncompahgre Plateau. The gravel was probably deposited by streams and locally by debris flows. Colors of the silty sand range from yellowish red (5YR5/8) to reddish yellow (5YR6/6); gravel lends a gray color to the unit. Secondary carbonate morphology on clasts and in the matrix is stage I-II.

Unit Qasy overlies Mancos Shale $(\mathrm{Km})$ and Dakota Formation (Kd) on the south side of the Colorado River. The upper part of unit Qasy is partly covered by unmapped thin sheetwash (Qsw) and colluvial debris (Qc) derived from bedrock units upslope and by thin, unmapped deposits of eolian sand $(\mathrm{Qe})$. The maximum thickness is about $15 \mathrm{~m}$.

\section{Qaso Older alluvial-slope deposits (late Pleistocene)-} Older alluvial-slope deposits consist chiefly of layers and lenses of poorly sorted, matrix- and clast-supported gravel and well-sorted silty sand and are found at the base of the mountain front.

The gravel clasts range in size from granules to boulders $1.5 \mathrm{~m}$ in diameter. These clasts are predominately metamorphic and igneous rocks derived from Proterozoic rocks and less abundant sandstone and limestone clasts derived from Mesozoic rocks to the south in the highlands in the Uncompahgre Plateau. The matrix of the gravel is silty sand. Gravel has light- to dark-gray colors from the clasts and a pink (5YR7/3-4) matrix. Gravelly zones exceed $6 \mathrm{~m}$ in thickness, and silty sand beds are 0.2 to $6 \mathrm{~m}$ thick. Most clasts are subangular to subrounded, but some of the angularity of the clasts appears to be related to weathering after deposition. The gravel layers are massive to poorly bedded, and, locally, gravel forms discontinuous lenses in thick beds of silty sand. Zones of non-sorted to very poorly sorted bouldery deposits suggest deposition as debris flows; some gravel deposits are better sorted and were probably deposited by alluvial processes. In the upper $0.3 \mathrm{~m}$ of the unit, secondary calcium carbonate in the matrix and on clasts has stage II morphology; at a depth of 5 to $6 \mathrm{~m}$, gravel is indurated by secondary calcium carbonate that has strong stage III morphology.
The silty sand layers are generally massive to weakly bedded and have colors that range from yellowish red (5YR5/8) to reddish yellow (5YR6/ 6). Where bedding is more distinct, the beds of silty sand are 0.1 to $0.5 \mathrm{~m}$ thick, and massive silty sand is locally as thick as $6 \mathrm{~m}$. Eolian processes may have initially deposited much of this silty sand. Some of it was probably reworked by stream and sheetwash processes. Unmapped discontinuous eolian deposits (Qe) and locally thin sheetwash deposits (Qsw) as much as 1 to 3 m thick partly mantle unit Qaso. Silty sand has stage I-II secondary calcium carbonate morphology at a depth of $6 \mathrm{~m}$.

Map unit Qaso commonly overlies Colorado River gravel (Qrg) near the bluffs on the south side of the Colorado River. Unit Qaso is locally exposed in the area between the Colorado River and the faulted front of the Uncompahgre Plateau. The top of unit Qaso is about 10 to $65 \mathrm{~m}$ above the Colorado River. Exposed thicknesses are at least 6 $\mathrm{m}$, and the maximum thickness suggested by topography is in excess of $20 \mathrm{~m}$.

Local gravel deposits (late? to middle Pleistocene)Local gravel deposits are poorly sorted, subrounded, clast- and matrix-supported pebble and cobble gravel that locally contains boulders as long as $2 \mathrm{~m}$. Unit Qlg was deposited by streams tributary to the Colorado River, and it probably includes both stream alluvium (Qal) as well as debris-flow deposits. Clasts consist primarily of metamorphic and igneous Proterozoic rocks and secondarily of sedimentary rocks eroded from the adjacent highlands in the Uncompahgre Plateau. These deposits form isolated remnants on hilltops in the Redlands area.

Thin lenses of silty sand and scattered granules and pebbles are present locally in unit Qlg. In the upper $2 \mathrm{~m}$ of the unit, secondary calcium carbonate coats clasts, and the matrix consists of yellowish-red (5YR5/6), calcium carbonate-rich (stage II), silty sand and granules.

Unit Qlg probably consists of remnants of stream-channel and debris-flow deposits that accumulated below the mouths of canyons along the front of the Uncompahgre Plateau. Eroded remnants of these former valley floors are preserved on hilltops at different heights between about 6 and $67 \mathrm{~m}$ above modern intermittent tributary streams. Assuming an incision rate of about $0.14 \mathrm{~m} / \mathrm{ky}$ for the Colorado River and its tributary streams, unit Qlg was deposited at different times between about $42 \mathrm{ka}$ and $480 \mathrm{ka}$. Gravel locally fills channels as deep as $1 \mathrm{~m}$ that are cut in the underlying bedrock. At one locality, east of Riggs Hill in the eastern part of the map area, unit Qlg 


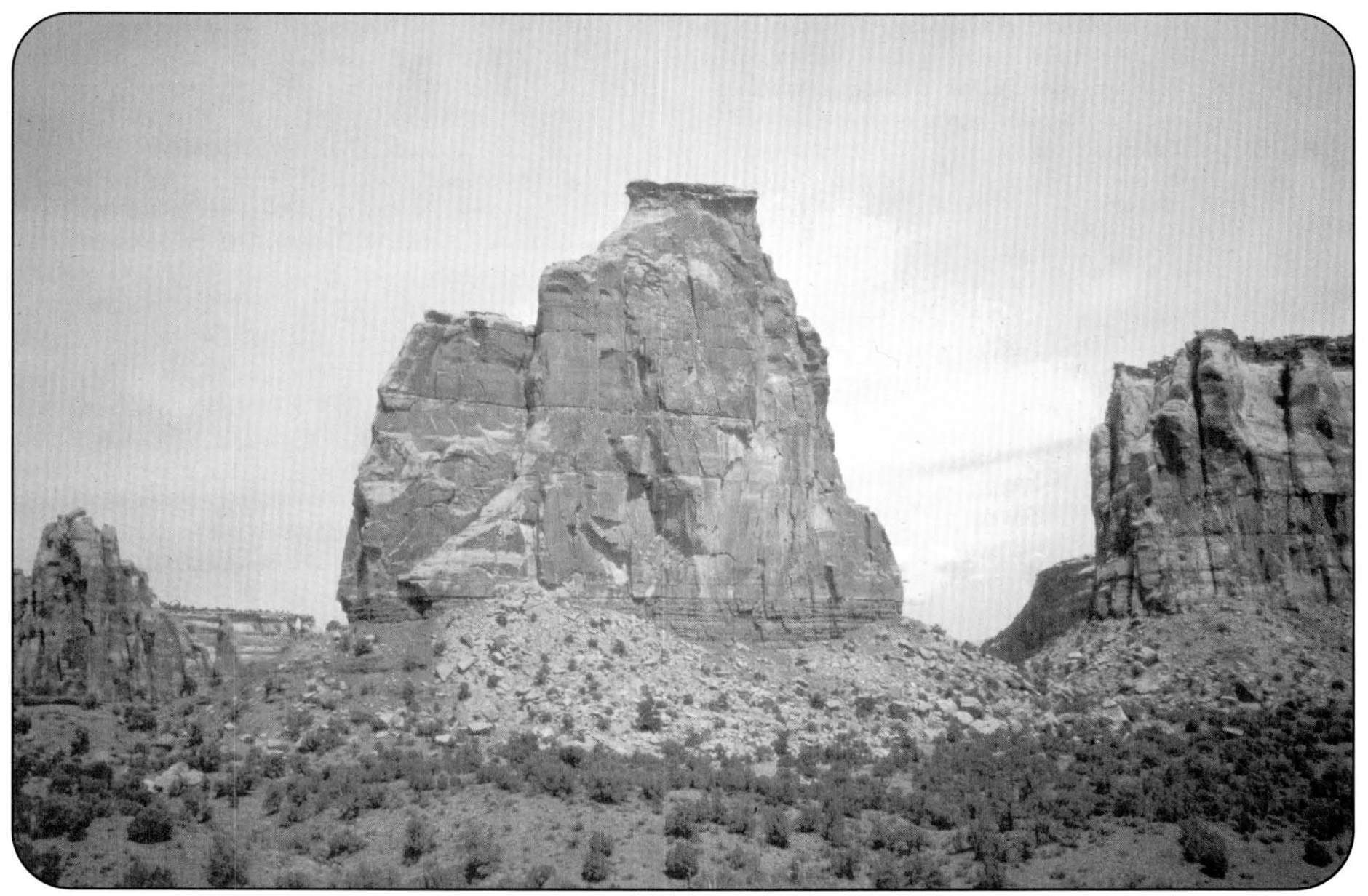

Independence Monument to the northwest as viewed from the Monument Canyon Trail. An apron of rock-fall deposits partially rings the base. Photograph by R.B. Scott, 1998.

overlies Colorado River gravel (Qrg). This indicates deposition of tributary gravel on a former flood plain or terrace of the Colorado River. The weathering of clasts, as indicated by the angularity of Proterozoic metamorphic and igneous clasts, is greater with age of the deposit and therefore is greater with height above stream level. Clasts of biotite-rich schist are particularly susceptible to both disaggregation and spheroidal weathering. Thin, unmapped veneers of Holocene eolian sand (Qe) mantle most of unit Qlg. The thickness of unit Qlg is as much as $6 \mathrm{~m}$.

Colluvial Deposits-Colluvial deposits include silt, sand, and rock fragments on valley sides and hill slopes that were mobilized, transported, and deposited by gravity and sheet erosion.

Qc Colluvium, undivided (Holocene and late Pleistocene)-Colluvium, undivided, consists mostly of clast-supported pebble, cobble, and boulder gravel with a matrix of silty sand, minor clayey silt, and, locally, gravelly silt and is found along the steeper slopes of the mountain front.
Rock type and colors of colluvium reflect the bedrock and surficial units from which the colluvium was derived. Unit Qc is commonly associated with rockfall deposits (Qr) at the base of cliffs of the Wingate Sandstone (Jwg). Locally, unit Qc includes sheetwash (Qsw), debris-flow, and landslide (Qlso and Qlsy) deposits. Colluvium derived from the Morrison Formation, contains expansive clays. Colluvium derived from the Chinle Formation $(\mathrm{Kc})$ is silty and non-expansive. Clasts are angular to subangular and are as large as $2 \mathrm{~m}$ in diameter. Secondary carbonate coatings on clasts in the upper part of the unit are thin and have stage I morphology. The maximum thickness is about $5 \mathrm{~m}$.

Or Rockfall deposits (Holocene and late Pleistocene)Rockfall deposits include boulders and smaller debris deposited on slopes at the base of cliffs, particularly cliffs of the Wingate Sandstone (Jwg).

The matrix is probably non-calcareous to calcareous, clast-supported, sandy rubble. Clasts are typically 1 to $2 \mathrm{~m}$ in diameter, but some exceed 12 
$\mathrm{m}$ in length. Clasts on younger rockfall deposits are unweathered and have light bedrock colors. Clasts on older rockfall deposits are weathered and coated with a brownish-gray to brownishblack desert varnish. The thickness of unit Qr is 1 $\mathrm{m}$ to greater than $3 \mathrm{~m}$.

Qlsy Younger landslide deposits (Holocene)-Younger landslide deposits are mostly intact, active or recently active earth-block slides (Varnes, 1978). These slides commonly have crescentic headwall scarps and form where the south side of the Colorado River has locally cut steep slopes on the uppermost Dakota Formation (Kd) and the lowermost Mancos Shale $(\mathrm{Km})$.

The sizes and rock type of the clasts and the grain-size distributions and colors of the matrices of these slides reflect those of the displaced bedrock units and surficial deposits. Landslide deposits are prone to continued movement or reactivation due to natural as well as humaninduced processes.

Blocks capped by units Qasy and Qaso have been downdropped to form small grabens, open tension gashes, and a series of slide blocks that step down toward the Colorado River. Closer to the river, these slide blocks are more disrupted. Upslope from the main scarp, incipient landsliding is indicated by cracks as much as $80 \mathrm{~m}$ from the river, where future breakaways will form. The toes of the landslides are being removed by the Colorado River. The presence of these young landslides indicates slope instability, which poses a hazard to roads or structures built on bluffs close to the river. In the adjacent Grand Junction 7.5minute quadrangle, young landslides have damaged a sewage treatment plant and an irrigation pump station. An active landslide was destroying a house near the eastern border of the map area south of the Colorado River as this map was being prepared. The thickness of unit Qlsy is at least $8 \mathrm{~m}$ and possibly as much as $35 \mathrm{~m}$.

Olso Older landslide deposits (late to middle? Pleistocene)-Older landslide deposits consist chiefly of unsorted and unstratified rock debris characterized by hummocky topography. Many of the landslides are complex (Varnes, 1978). All of them formed on unstable slopes that are underlain by the Brushy Basin Member of the Morrison Formation (Jmb). These landslide deposits include debris from the Brushy Basin Member of the Morrison Formation (Jmb), the Burro Canyon Formation $(\mathrm{Kb})$, and the Dakota Formation $(\mathrm{Kd})$, and are particularly abundant on the slopes of Black Ridge. Landslide deposits are prone to continued movement or reactivation due to natural as well as human-induced processes.
Most of the map unit lacks distinctive landforms such as crescentic headwall scarps and lobate toes, but the deposits have hummocky surfaces. Rejuvenated parts of unit Qlso have crescentic headwall scarps shown on the map by hachured lines. Unit Qlso includes debris-slide, rock-slide, debris-slump, rock-slump, slumpearth-flow, earth-flow, and debris-flow deposits as defined by Varnes (1978).

The sizes and rock types of the clasts and the grain-size distributions and colors of the matrices of these deposits reflect those of the displaced bedrock units and surficial deposits. Deposits derived from the Dakota Formation $(\mathrm{Kd})$ and the Burro Canyon Formation $(\mathrm{Kb})$ contain blocks of rock as long as $6 \mathrm{~m}$. Landslide deposits derived from the Brushy Basin Member of the Morrison Formation (Jmb) are rich in clay. Brushy Basinderived clay contains expansive smectitic clay and locally has high shrink-swell potential.

In the west-central part of the map area, landslides as long as $2.5 \mathrm{~km}$ flank the west, north, and east sides of Black Ridge. These landslides flowed over the rim of Monument Canyon and locally cover the Proterozoic rocks exposed on the canyon floor. The northeast-dipping Brushy Basin Member of the Morrison Formation (Jmb), the Burro Canyon Formation $(\mathrm{Kb})$, and the Dakota Formation (Kd) have been involved in landslides that have moved toward the Colorado River. Housing or other development in this area may encounter landslide hazards. The exposed thickness is about $5 \mathrm{~m}$, and the maximum thickness is possibly $20 \mathrm{~m}$.

Qsw Sheetwash deposits (Holocene and late Pleistocene)Sheetwash deposits consist chiefly of light-gray (10YR7/2 and 2.5Y7/2) sandy clay and silty clay. These sheetwash deposits form on a very gentle slope with a gradient of about 3 to $4 \mathrm{~m} / \mathrm{km}$ north of the Colorado River where they were derived by erosion of the Mancos Shale ( $\mathrm{Km})$.

The upper $1 \mathrm{~m}$ of sheetwash deposits is more clay rich than the lower part. Both the upper and lower parts have weak sub-horizontal layering and are slightly calcareous. Unit Qsw commonly has vertical desiccation cracks that are partly filled with clay, which probably washed down from the upper part.

Extensive agricultural, industrial, and housing development has modified, covered, or partly removed the upper part of much of unit Qsw near the northeast corner of the map area. This unit description is based on observations of exposures in an eroded bank of a 4-m-deep agricultural drainage ditch located $3.2 \mathrm{~km}$ north and $0.2 \mathrm{~km}$ west of the intersection of $\mathrm{H}$ Road and 21 Road in the adjacent Fruita 7.5-minute quadrangle. 
The presence of desiccation cracks suggests that the map unit contains expansive clays that may cause stability problems for roads and buildings. Our examination of construction excavations and records from numerous drill holes on the north side of the Colorado River (Ken Weston, U.S. Bureau of Reclamation, written commun., 1999; Phillips, 1986) indicates that sheetwash deposits are 3 to $8 \mathrm{~m}$ thick close to the river, but increase to nearly $15 \mathrm{~m}$ thick at the northeastern corner of the map area.

Eolian Deposits-Eolian deposits consist of silty sand that manthes level to gently sloping surfaces. Locally they include colluvial material.

Qe Eolian sand (Holocene and late Pleistocene)-Eolian sand consists of silty, very fine to fine wind-blown sand that blankets upland areas of the Uncompahgre Plateau.

These deposits are commonly massive to weakly bedded and lack eolian sedimentary structures, which may have been obliterated by biotic processes. Deposits at depths greater than $1 \mathrm{~m}$ are typically weakly indurated by secondary calcium carbonate that has stage I morphology. Colors generally range from yellowish red (5YR5/8) to reddish yellow (5YR6/6). The sand is derived chiefly from weathering of the poorly cemented Slick Rock Member (Jes) and the "board beds" unit (Jeb) of the Entrada Sandstone and of the Wingate Sandstone (Jwg); lesser amounts are derived from sandstone of the members of the Morrison Formation (Jmt, Jms, and Jmb). Deposits of eolian sand at the base of bedrock exposures locally may contain a significant amount of colluvial debris. Clast sizes in colluvial debris range from granules to boulders. On slopes, eolian sand is subject to redeposition as sheetwash. Several climbing dunes are banked against bedrock and are as thick as $5 \mathrm{~m}$.

Thin, discontinuous, unmapped deposits of eolian sand mantle other surficial deposits and bedrock on the upland areas of the Uncompahgre Plateau and in the Redlands area near the Colorado River. In the upland areas, deposits of eolian sand locally form subdued, stabilized dunes and blankets of eolian sand. Eolian sand on the uplands is locally stabilized by pinon and juniper trees and in other areas by sage, rabbitbrush, bunch grass, and cheat grass. Structures built on unit Qe commonly sustain minor damage that suggests slight settling, probably chiefly related to hydrocompaction. Deposits of eolian silt (loess) were not observed in the map area, although they are locally common further upstream along the Colorado River between Rifle and Glenwood Springs (Shroba, 1994). The thickness of unit Qe may locally be in excess of $8 \mathrm{~m}$.
Eolian and Colluvial Deposits-Eolian and colluvial deposits include silty sand, which mantles level to gently sloping surfaces, as well as silt, sand, and rock fragments on valley sides and hill slopes, which were mobilized, transported, and deposited by gravity and sheet erosion.

Qse Eolian sand and sheetwash deposits (Holocene and late Pleistocene)-Eolian sand and sheetwash deposits consist chiefly of silty, very fine to fine sand that commonly contains scattered granule- to cobble-size fragments from bedrock units that are exposed upslope, particularly between the mountain front and the Colorado River.

Unit Qse accumulated on gentle to moderate slopes with gradients between about $50 \mathrm{~m} / \mathrm{km}$ and $100 \mathrm{~m} / \mathrm{km}$. Unit Qse is similar to unit Qe, but unit Qse contains more abundant clasts derived from local bedrock units. On steeper slopes near upslope bedrock exposures, unit Qse is likely to contain a significant amount of colluvial clasts. Sheetwash deposits in unit Qse contain discontinuous layers and lenses of poorly sorted clasts. Colors of the unit range from yellowish red (5YR5/8) to reddish yellow (5YR6/6). Where wind and sheetwash erosion have winnowed out sand and finer sediment, a lag of granules, pebbles, and sparse cobbles covers the surface. Unit Qse formed along the front of the Uncompahgre Plateau where it mantles unit Qaso and other units. The thickness of unit Qse may be about $5 \mathrm{~m}$.

Marsh Deposits-Marsh deposits include wind- and (or) sheetwash-deposited sand and silt that accumulated in a wet environment.

Qcg Cienaga deposits (Holocene)-Cienaga deposits consist of silty sand that has chiefly an eolian and (or) sheetwash origin; the deposits accumulated in marshy places in the Redlands area.

These marshy areas are fed by seeps, are generally well vegetated, and are upstream from constrictions formed by resistant beds of the Burro Canyon Formation $(\mathrm{Kb})$ and the Dakota Formation (Kd). Unit Qcg largely overlies the relatively impermeable Brushy Basin Member of the Morrison Formation (Jmb). The deposits in unit Qcg are massive, well sorted, structureless, and lack gravelly layers. Locally they may contain some sandy stream alluvium. Colors are commonly light reddish brown (2.5YR6/4) to pale red (10R6/3) at a depth of 10 to $24 \mathrm{~cm}$ and red $(2.5 Y R 5 / 6)$ at a depth of greater than $40 \mathrm{~cm}$. The upper 10 to 24 $\mathrm{cm}$ of unit Qcg is moderately indurated and slightly calcareous, whereas sediment below a depth of $40 \mathrm{~cm}$ is weakly indurated and very slightly calcareous. 


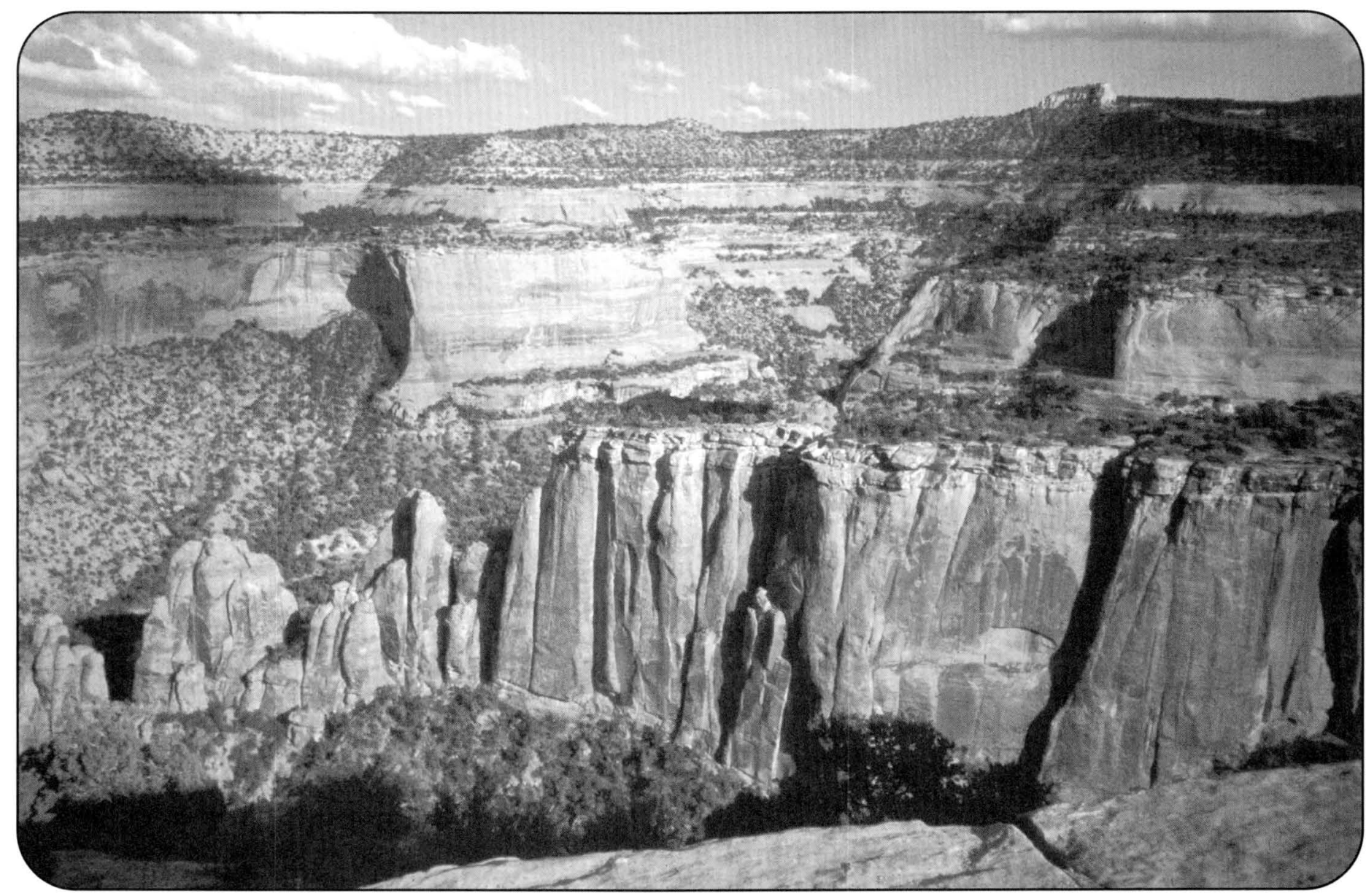

View to the southeast from Artists Point. Cliffs in the distance expose from bottom to top, the Chinle Formation at the base, high cliffs of the Wingate Sandstone, a tree-covered bench of the Kayenta Formation, and small cliffs of the Entrada Sandstone, all capped by tree-covered slopes of the Wanakah and Morrison Formations. Photograph by R.B. Scott, 1998.

Unit Qcg is soft when saturated with water, and the underlying Brushy Basin Member (Jmb) contains abundant expansive clay (smectite). As a result, unit Qcg has low bearing capacity and poses a hazard to roads and structures built on it. In a few low areas where the water table is at or near the surface, evaporation leaves a dissolved load precipitate of alkali crust on unit Qcg. Areas that have this crust are designated on the map by a dotted perimeter and the symbol "a". This alkali crust is commonly a few centimeters thick, white (5YR8/1), and mostly devoid of vegetation. The thickness of unit Qcg is 1 to $3 \mathrm{~m}$.

\section{Bedrock Units}

To make the bedrock unit descriptions easier for the nongeologist to read, the first few paragraphs of each describes general characteristics, modern-day analogs for depositional environments, and locations of good exposures. The remaining parts of the unit description provide more detailed technical information.
$\mathrm{Km}$

Mancos Shale (Upper Cretaceous; Turonian and Cenomanian)-The Mancos Shale is chiefly a medium-dark-gray, dark-gray, brownish-gray, and brownish-black fissile shale that forms gentle slopes, which are broken at wide intervals by thin, brownish-gray sandstone ledges and sparse, white bentonite beds. Only the lowermost Man$\cos$ Shale is exposed along the northern boundary of the map area near the Colorado River. This lowermost Mancos was deposited in a shallow marine subtidal setting, similar to the modern Texas Gulf Coast.

Exposures of the Mancos Shale can be seen on the south side of the Colorado River, southwest of the Redlands Parkway bridge that has been constructed at the east boundary of the map area. This bridge is not shown on the topographic base map available for this quadrangle but is shown on modern street maps.

In addition to the dominant dark fissile shale that weathers light gray, the lowermost Mancos contains sparse beds of thinly laminated, fissileweathering, partly bioturbated, calcareous and 
carbonaceous siltstone and sandy siltstone, which contain sparse interbeds of sandstone. The unit is well defined by Cobban and others (1994). The sandstone is very fine to fine grained, well sorted, and calcareous and has beds that are typically less than $10 \mathrm{~cm}$ thick. The beds commonly exhibit ripple lamination, including both oscillation and combined flow ripples, and locally display hummocky cross-lamination. Several light-gray to yellowish-gray thin stringers and beds of volcanic ash have been altered to nearly pure, highly expansive bentonite and are as much as $20 \mathrm{~cm}$ thick.

The lowermost Mancos is fossiliferous, but pelecypods and cephalopods are generally found only in recent roadcuts and excavations because rapid weathering breaks up fossils. Marine trace fossil burrows are common. The base of the Mancos was mapped at the base of the nearly continuous dark fissile shale above the uppermost prominent set of thin sandstone beds and carbonaceous interbeds of the Dakota Formation $(\mathrm{Kd})$. The map unit reaches a thickness in excess of $1,370 \mathrm{~m}$ in western Colorado; however, less than $20 \mathrm{~m}$ of the lowermost Mancos is exposed south of the Colorado River in the map area (Cole and Moore, 1994; Cole and others, 1999).

\section{Kd Dakota Formation (Upper and Lower? Cretaceous;} Cenomanian and Albian?)-Sandstone and conglomerate of the Dakota Formation form prominent and resistant ledges and ridges, whereas mudstone and interbedded sandstone and shale of the Dakota generally form slopes. The Dakota Formation caps Black Ridge near the central western boundary of the map area and forms a series of low hogbacks in the Redlands area south of the Colorado River. Locally in the Redlands area, dinosaur tracks are preserved in the sandstone beds.

The sandstone and mudstone of the upper parts of the Dakota were deposited in estuaries, tidal channels, distributary channels, bays, lagoons, strandlines, and barrier islands, an environment similar to the Texas Gulf Coast today. Bioturbation is common throughout the map unit and includes plant roots and burrows. Burrows in the lower Dakota are terrestrial in origin, whereas those in the upper Dakota are marginal-marine. The lowest part of the Dakota, which is dominated by channel-form sandstone and conglomerate bodies, was deposited by slightly to moderately sinuous streams flowing across broad, welldefined flood plains that were densely vegetated and contained numerous abandoned channels that formed oxbow lakes. The carbonaceous mudstone and associated coal were deposited in freshwater swamp and marsh environments.
Good exposures of the Dakota Formation are not easily reached on public land in the map area. However, a trail up the south side of Riggs Hill leads from a parking area on South Broadway to the top of the hill, which is capped by the Dakota.

The unit consists of about 20 to $50 \%$ sandstone, 5 to $20 \%$ conglomerate, 40 to $60 \%$ mudstone, and less than $5 \%$ impure coal. There are four parts to the map unit: from top to bottom these are the interbedded sandstone and shale part, a sandstone part, a mudstone part, and a conglomeratic part. The interbedded sandstone and shale part is dominantly shale or shaley mudstone, thin sandstone beds, and stringers of coal. Shale in the uppermost part of the Dakota is interbedded with channel-form sandstone, is usually much less carbonaceous than elsewhere in the unit, and consists of brownish-gray to greenish-gray, thinly laminated, fissile-weathering, slightly carbonaceous, slightly calcareous, siltstone and clayey siltstone. This interbedded sandstone and shale part is bioturbated by roots and indistinct burrows. This upper part is transitional with the overlying Mancos Shale (Km).

The sandstone part contains predominately sandstone with subordinate conglomerate, stringers of coal, and minor mudstone. Sandstone is commonly light gray to pale yellowish orange, white, pinkish gray or very pale orange, very fine to fine grained, moderately to poorly sorted, bioturbated, locally argillaceous, and slightly calcareous to non-calcareous. The sandstone part is thickly bedded to very thinly bedded. Thicker sandstone bodies ( 1 to $5 \mathrm{~m}$ ) have a channel-form geometry with associated scour surfaces and lag gravels, which include blebs of mudstone, chert, quartz, and rock fragments. Stratification consists of small- to medium-scale trough and tabular-tangential cross-stratification, symmetric and asymmetric ripple lamination, horizontal lamination, and contorted bedding.

The mudstone part is chiefly mudstone and subordinate impure coal. Mudstone consists of brownish-gray to grayish-black, medium- to thinly laminated, platy to fissile weathering, carbonaceous to very carbonaceous, bioturbated, silty claystone and clayey siltstone containing thin beds and lenses of very fine to fine-grained, quartz-cemented sandstone and white, altered volcanic ash. Fragments of plant fossils are very common. Impure coal seams and stringers, ranging in thickness from 5 to $40 \mathrm{~cm}$, are found within the carbonaceous mudstone. The ash content in the coal is estimated at 15 to 35 percent. 
Although the conglomeratic part is capped by sandstone, conglomerate predominates. The conglomerate part contains clasts that range in size from fine sand to pebbles and is typically light gray to white or pinkish gray, poor to moderately sorted, slightly argillaceous, slightly calcareous to non-calcareous, and friable. Also the conglomerate part has medium to very thick beds, blocky and slabby weathering, and contains minor sandstone interbeds. Clasts are commonly graded and consist of mud chips, chert, quartz, and other rock fragments. Stratification in conglomerate is generally indistinct, consisting of poorly defined lowangle $\left(<15^{\circ}\right)$ scour surfaces.

The map unit may rest disconformably on the underlying Burro Canyon Formation. The base of the Dakota Formation was arbitrarily defined during mapping as the first carbonaceous mudstone above the Burro Canyon Formation $(\mathrm{Kb})$. The first thick sandstone interval above the carbonaceous mudstone of the Dakota Formation commonly has been bleached white in contrast to light yellow and orange elsewhere. The thickness of the map unit exposed at Black Ridge is about $31 \mathrm{~m}$ where the uppermost part of the unit has been removed by erosion, and the total unit thickness is estimated to be about 45 to $50 \mathrm{~m}$ (Cole and others, 1999).

Kb Burro Canyon Formation (Lower Cretaceous; Albian and Aptian)-In most localities, the upper part of the Burro Canyon Formation is dominated by mudstone and forms slopes, whereas the lower third to two-thirds of the unit is dominated by sandstone and forms cliffs.

The thick mudstone sequence at the top of the unit represents flood plain and lacustrine deposition. The sandy lower part of the Burro Canyon was deposited by braided streams on narrow flood plains. Modern rivers draining the Rocky Mountains, such as the parts of the South Platte and Rio Grande Rivers that are in the plains, are possible analogs for the depositional systems that deposited the Burro Canyon.

The Burro Canyon Formation can most readily be reached by following the same trail as that used to reach the Dakota Formation. Go part way up the trail on the south side of Riggs Hill from South Broadway to the first exposures of coarse conglomerate, which mark the base of the Burro Canyon.

The map unit consists of about 40 to $80 \%$ mudstone, 20 to $60 \%$ sandstone, and 0 to $15 \%$ conglomerate. Mudstone is typically medium to thinly laminated (platy to fissile weathering), slightly bentonitic to non-bentonitic, slightly calcareous, and commonly bioturbated by roots and some burrows. Mudstone consists of palered, pale-olive to yellowish-green siltstone, clayey siltstone, and silty claystone and ranges from thin interbeds within channel-form sandstone bodies to discrete sequences more than 10 $\mathrm{m}$ thick. Thin (less than $1 \mathrm{~m}$ thick) paleosol horizons that are composed of white to light-gray, earthy carbonate nodules may be interbedded with mudstone in the upper Burro Canyon.

Sandstone intervals are laterally discontinuous. Sandstone forms channel-shaped bodies and is typically white to yellowish gray, thick bedded to thinly laminated, blocky to flaggy weathering, fine to medium grained, moderately sorted, and quartz-cemented. Locally the sandstone includes large amounts of petrified wood. Sandstone sequences contain numerous laterally and vertically amalgamated scour surfaces accentuated by thin lag gravels, which include green mudstone clasts, chert, quartz, petrified wood, and dinosaur bone. Medium-scale trough and tabular-planar cross-stratification is common in sandstone bodies; contorted bedding and bioturbation, including roots and elongate vertical burrows, are also present.

Locally, conglomerate beds are as much as $3 \mathrm{~m}$ thick near the base of the map unit; conglomerate is commonly yellowish gray, moderately sorted, well rounded, massive to poorly bedded, channel form, and discontinuous laterally. The conglomerate clasts consist mostly of chert and quartz pebbles but include minor petrified wood and dinosaur bone.

The base of the map unit is arbitrarily defined as the lowest thick sandstone or conglomerate bed above the mudstone of the Brushy Basin Member of the Morrison Formation (Jmb) (Aubrey, 1998). The thickness of the map unit is $29.3 \mathrm{~m}$ at Black Ridge (Cole and others, 1999).

Morrison Formation (Upper Jurassic)-The Morrison Formation consists of three members: a slopeforming upper member, the Brushy Basin Member; a cliff-forming middle member, the Salt Wash Member; and a slope-forming lower member, the Tidwell Member. The Morrison Formation is about $160 \mathrm{~m}$ thick based on the total measured thickness of the three members (Cole and others, 1999). However, individual members do not have laterally consistent thicknesses; therefore, the total thickness of the Morrison may be significantly different from place to place. 


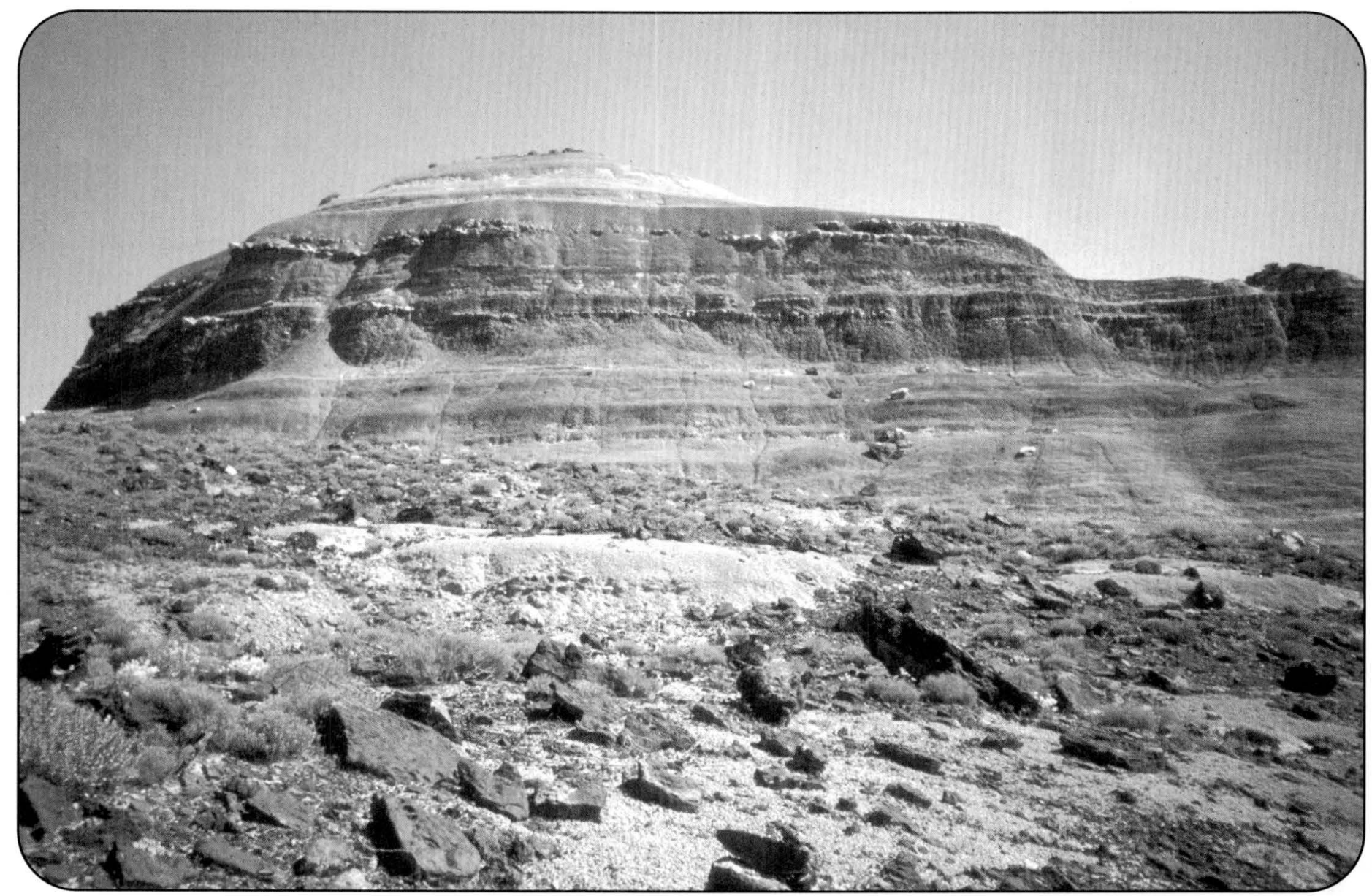

Typical exposures of mudstone of the Brushy Basin Member of the Morrison Formation in the Redlands. Photograph by R.B. Scott, 1998.

\section{Jmb}

Brushy Basin Member (Tithonian and Kimmeridgian)-The multicolored mudstone of the Brushy Basin Member forms gentle rounded slopes. The Brushy Basin Member was deposited in a mud flat to saline lacustrine setting (Turner and Fishman, 1991) that was locally invaded by highly sinuous fluvial channels. Volcanic basins in New Zealand are possible modern-day analogs.

Like the Dakota and Burro Canyon Formations, the Brushy Basin Member of the Morrison Formation can be reached by following the trail from the parking area off South Broadway up Riggs Hill. The mudstone is partly covered by blocks of sandstone and conglomerate that tumbled from exposures of the Dakota and Burro Canyon.

The unit consists of 85 to $95 \%$ mudstone, 5 to $15 \%$ sandstone, and a trace of limestone. About $75 \%$ of the mudstone consists of bentonitic, variegated grayish-yellow-green, greenish-gray, yellowish-gray, brownish-gray, grayish-red, greenish-yellow, and grayish-orange-pink, medium to thinly laminated (platy to fissile weathering), mottled, bioturbated (?), earthy, slightly calcareous, clay-rich siltstone, mudstone, and silty mudstone. The silty mudstone contains thin interbeds of very fine grained, well-sorted, bioturbated sandstone and gray, nodular, finely crystalline limestone (possible soil nodules?). Barite nodules and dinosaur bones are present. Bentonitic mudstone expands and dries to form a popcorn-like weathered surface. Bentonite, a rock consisting of swelling, mixed-layer, smectitic clay minerals, is derived from diagenetic alteration of volcanic ash.

The remaining $25 \%$ of the mudstone that is not conspicuously bentonitic consists of variegated pale-olive, reddish-brown, greenish-gray, grayishyellow-green, yellowish-gray, yellowish-orange, and grayish-red, thickly to thinly laminated (flaggy to fissile weathering), partly bioturbated, slightly calcareous to non-calcareous siltstone, sandy siltstone, and silty mudstone. The silty mudstone also contains thin interbeds of very fine grained sandstone. Sandstone is most common in the lowermost and uppermost Brushy Basin Member and typically forms channels and ranges 
in thickness from less than $1 \mathrm{~m}$ to more than $4 \mathrm{~m}$. Sandstone is typically greenish yellow to dusky yellow green and greenish gray, very fine to coarse grained, poor to moderately sorted, slightly calcareous to non-calcareous, and locally bioturbated by burrows and roots and contorted by softsediment deformation. Sandstone has thickly laminated to medium bedding and slabby to flaggy weathering. The thicker channel sequences commonly have small-scale trough cross-stratification and scour surfaces accentuated by basal layers of pebble-size mudchips and granules of chert and quartz, whereas thinner sandstone beds are commonly bioturbated.

Because of its susceptibility to mass wasting, particularly landsliding, the Brushy Basin Member is one of the most poorly exposed units in the map area. The Brushy Basin Member underlies the K-1 unconformity (Peterson, 1994; Peterson and Turner, 1998) below the Burro Canyon Formation and rests disconformably above the Salt Wash Member (unnamed unconformity; R.G. Young, oral commun., Grand Junction, Colo., 1999). The Brushy Basin Member is about $95 \mathrm{~m}$ thick at exposures about $1 \mathrm{~km}$ east of the east boundary of the map area near Little Park Road in the adjacent Grand Junction 7.5-minute quadrangle (Cole and others, 1999).

Salt Wash Member (Kimmeridgian)-The Salt Wash Member is a sandstone-rich cliff-forming unit sandwiched between the mudstone-rich, slope-forming Brushy Basin and Tidwell Members of the Morrison Formation. The Salt Wash Member was deposited in a fluvial setting that included associated flood plains and shallow ponds. The architecture of the channel-form sandstone bodies suggests that the fluvial channels were relatively thin ( 1 to $7 \mathrm{~m}$ ), narrow $(5$ to $30 \mathrm{~m}$ ), and moderately sinuous. An analog for this depositional setting exists along the modern-day Texas coast where rivers empty into the Gulf of Mexico.

Some of the best exposures of the Salt Wash Member of the Morrison Formation can easily be seen in road cuts on Rim Rock Drive south of Highland View Overlook.

The unit consists of 30 to $80 \%$ sandstone, 20 to $70 \%$ mudstone, and traces of limestone; the unit is well defined by Peterson (1994). Sandstone typically is fine to medium grained, moderately sorted, slightly calcareous, and friable. Sandstone forms very pale orange, yellowishgray and light-gray, channel-shaped bodies that range from 1 to $5 \mathrm{~m}$ thick, is very thinly to very thickly bedded, and has slabby to blocky weathering. Thicker sand bodies commonly exhibit small- to large-scale trough, tabular-tangential, and sigmoidal cross-bedding, as well as scour surfaces accentuated by granule- to pebble-size lag gravels composed of red and green mudstone, quartz, and chert. Elongate, narrow burrows are common near the tops of the thicker sand bodies.

Mudstone intervals consist of pale-brown to greenish-yellow, grayish-red, and yellowish-gray, silty claystone, siltstone, sandy siltstone, and mudstone. Mudstone occurs as 0.1- to 1-m-thick interbeds between sandstone channels, but can also exist as sequences as much as $15 \mathrm{~m}$ thick where sandstone channels are poorly developed. These mudstone bodies are commonly thickly to thinly laminated, flaggy to fissile weathering, slightly calcareous, slightly bentonitic, and commonly bioturbated by insect burrows and plant roots. Wellcemented, mottled mudstone intervals weather to form nodules. Thicker mudstone sequences commonly have thin interbeds and lenses of very fine to fine-grained, well-sorted sandstone.

Minor limestone beds are very similar to the limestone beds in the underlying Tidwell Member, are usually light gray to light olive gray, slightly sandy to silty, mottled, bioturbated, finely crystalline, slightly fossiliferous, containing ostracodes and charophytes, and have the mudmatrix-supported fabrics of carbonate mudstone and wackestone. These beds are present as scattered discontinuous beds less than $0.3 \mathrm{~m}$ thick and as beds of nodules within mudstone.

The Salt Wash-Brushy Basin contact is commonly obscured because of mass wasting. The base of the Salt Wash Member was defined during mapping as the top of the uppermost major limestone bed of the Tidwell Member (Jmt) below the thick sandstone beds of the Salt Wash Member. The Salt Wash Member exhibits considerable lateral variation in thickness and rock type within the quadrangle; on the east side of the map area, the member becomes only a few meters thick and may be locally absent in the adjacent Grand Junction quadrangle. The thickness of the member is $31 \mathrm{~m}$ at Artists Point on Rim Rock Drive (Cole and others, 1999).

Tidwell Member (Kimmeridgian and Oxfordian)-The mudstone-rich Tidwell Member forms slopes that are broken by relatively thin ledges of sandstone and limestone; with rare exception, this is the only limestone in the map area. Within the Tidwell Member, the character and thickness of mudstone, sandstone, and limestone change significantly laterally.

The heterolithic nature of the Tidwell indicates that it was deposited in several environments. The green mudstone sequences and all of the limestone were probably deposited in a freshto brackish-water lacustrine setting. Tabular 
sandstone bodies characterized by horizontal stratification and oscillation ripples were deposited on beaches in lake-margin settings, whereas the channel-form sandstone bodies with crossstratification were deposited by fluvial and distributary channel systems.

Excellent exposures of the Tidwell Member of the Morrison Formation can be seen in road cuts along Rim Rock Drive between Artists Point and Highland View Overlook.

The unit consists of laterally variable proportions of interbedded 50 to $70 \%$ mudstone, 10 to $40 \%$ sandstone, and 5 to $20 \%$ limestone; the unit is well defined by Peterson (1994). Mudstone typically consists of grayish-red to grayish-yellow-green sequences of mudstone, sandy siltstone, silty claystone, and siltstone, ranging in thickness from a few centimeters to more than 4 $\mathrm{m}$. These sequences are commonly very thin bedded to thinly laminated, slabby to fissile weathering, mottled, bioturbated by roots and burrows, and slightly calcareous to very calcareous. Calcareous mudstone intervals have a nodular weathering aspect.

Sandstone is light gray to light greenish gray, fine to medium grained, moderately to well sorted, calcareous, and locally bioturbated by roots and burrows. The sandstone has slabby to blocky weathering. Sedimentary structures in sandstone include horizontal lamination; discontinuous, wispy, bedding-parallel lamination; wavy, bedding-parallel, hummocky lamination; small- to medium-scale trough and tabular-tangential cross-stratification; and asymmetric current and symmetric wave ripple stratification. Sandstone beds range in thickness from less than $1 \mathrm{~cm}$ to about $2 \mathrm{~m}$ and exhibit both tabular and channel-form cross-sectional geometry.

The lowermost sandstone package that defines the base of the Tidwell is informally called "A" bed, rests on the J-5 unconformity (Pipiringos and O'Sullivan, 1978), and is continuous throughout

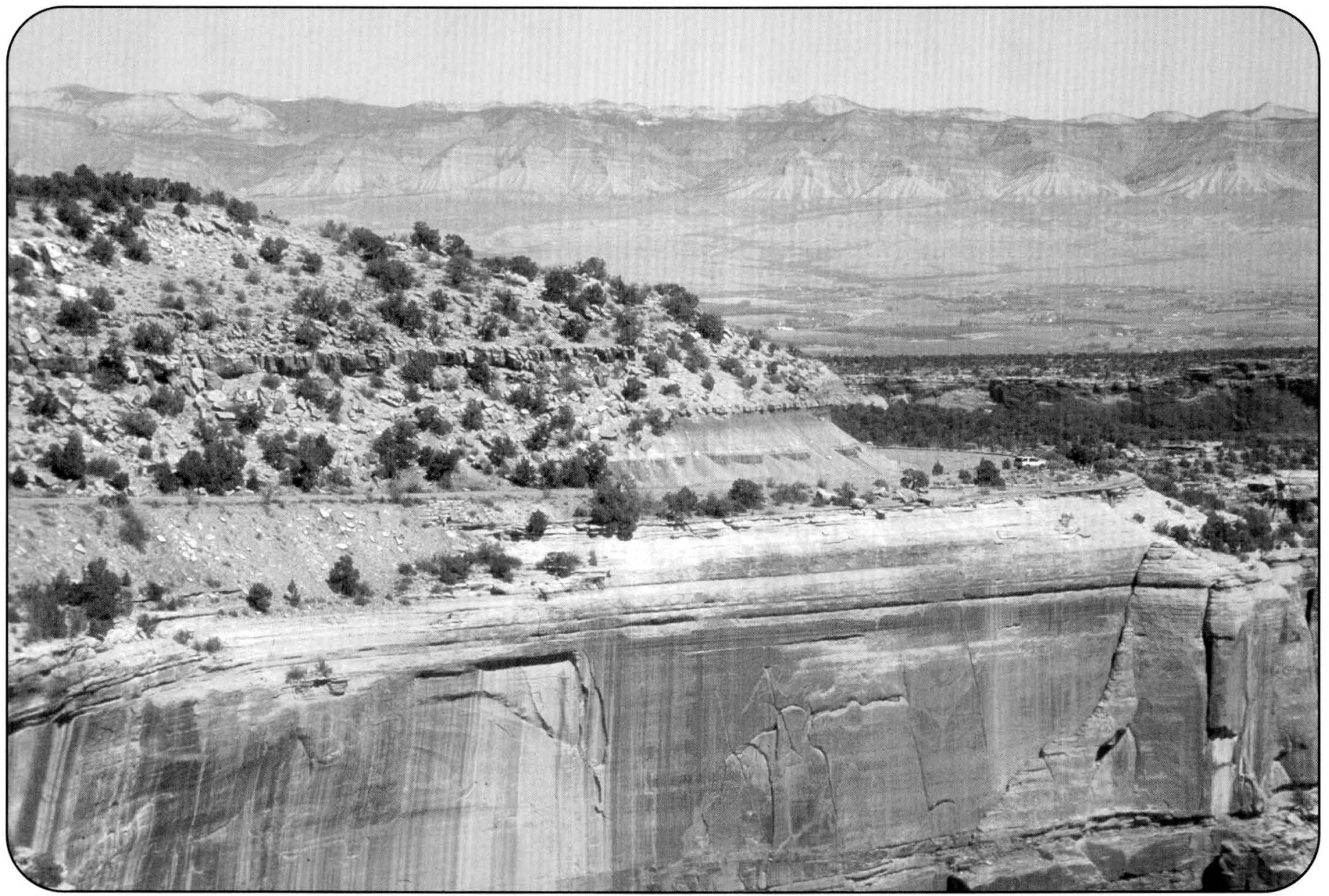

Above the cliffs of the Entrada Sandstone at Artists Point are the bare slopes of the mudstone of the Wanakah Formation overlain by tree-dotted slopes of the Tidwell Member of the Morrison Formation. Photograph by W.C. Hood, 1998. 
the quadrangle. The "A" bed, which is approximately $1 \mathrm{~m}$ thick, has a basal lag composed of oversize (medium-grained to granule) chert and lithic grains; similar granule lenses also occur within this bed.

Between 2 and 7 limestone beds are present and are most abundant in the upper half of the Tidwell. Limestone is typically light gray to light olive gray, dense, hard, slightly sandy or silty, very fine to finely crystalline, and resistant to weathering, forming slabby to blocky exposures. Most limestone is mottled and bioturbated by burrows, although stromatolitic lamination produced by algal (cyanobacteria?) growth is locally present. Oncolites (algal biscuits) are also found. Fossils are sparse and consist of ostracodes, charophytes, and very small gastropods. Petrographically, the Tidwell limestone is classified as carbonate mudstone, and packstone (Dunham, 1962). Limestone beds range in thickness from several centimeters to about $1 \mathrm{~m}$.

The Tidwell rests on the Wanakah Formation (Jw), which is below the J-5 unconformity (Peterson, 1994), whereas the upper contact with the overlying Salt Wash Member of the Morrison Formation is transitional. Because the map unit does not contain thin, parallel-bedded gypsiferous strata typical of the Summerville Formation south and west of the map area (Anderson and Lucas, 1998), the name "Tidwell Member of the Morrison Formation" is retained locally. The Tidwell Member is about $38 \mathrm{~m}$ thick at Artists Point along Rim Rock Drive (Cole and others, 1999).

Jw Wanakah Formation (Middle Jurassic; Callovian)— In Colorado National Monument, the mudstonerich, slope-forming Wanakah is easily recognized by its distinctive green-over-red colors and by a noticeable reduction of vegetation. The depositional setting for the Wanakah is nonmarine mudflat and (or) shallow lacustrine environment.

The entire Wanakah Formation is exposed at Artists Point on Rim Rock Drive.

The Wanakah Formation consists of 80 to $90 \%$ interstratified mudstone, 5 to $15 \%$ sandstone and silty sandstone, 0 to $5 \%$ impure limestone, and traces of volcanic ash and gypsum. Mudstone consists of reddish-brown, grayish-red-purple, yellowish-brown, pale-olive, and greenish-gray siltstone, sandy siltstone, and mudstone. The greenish-gray mudstone is dominant in the upper half of the unit. Mudstone intervals are medium to thinly laminated and are platy, fissile and nodular weathering, mottled, bioturbated by burrows and roots, slightly calcareous, and non-bentonitic.

Sandstone, which occurs as very thin to thin, slabby weathering interbeds and discontinuous lenses in mudstone, is typically light brown to light gray, very fine to fine grained, moderately to well sorted, silty, bioturbated, and calcareous. The sandstone displays discontinuous horizontal lamination and asymmetric ripple lamination.

Limestone forms gray to grayish-red and lightgray, sandy to silty, bioturbated, discontinuous nodules that are usually less than $5 \mathrm{~cm}$ in diameter.

Radiometric analysis shows a large positive gamma-ray anomaly approximately $5 \mathrm{~m}$ above the base that is associated with several light-grayishgreen, volcanic ash laminae less than $1 \mathrm{~cm}$ thick (Cole and others, 1999). The Wanakah is truncated by the $\mathrm{J}-5$ unconformity (Pipiringos and O'Sullivan, 1978), which shows minimal erosional relief throughout the map area. Beneath the unconformity, the upper several meters of the Wanakah have numerous well-developed root traces. The base of the Wanakah Formation is defined at the base of the red mudstone that rests on the very pale orange to very light gray sandstone beds of the upper informal "board beds" unit of the Entrada Sandstone. The map unit is $9.4 \mathrm{~m}$ thick at Artists Point on Rim Rock Drive (Cole and others, 1999).

Entrada Sandstone (Middle Jurassic; Callovian)_The Entrada Sandstone consists of two parts, the prominent white cap of the upper unit, informally called the "board beds," and the pale-orange, ribbon-like lower Slick Rock Member.

"board beds" unit-Interbedded resistant sandstone and less resistant mudstone form slabby exposures that resemble a stack of boards, giving the "board beds" unit its informal name. This unit was deposited in a wet sand-flat environment in a coastal setting. The western coast of Baja California, Mexico, at Guerrero Negro, may be a possible modern-day analog (Fryberger and others, 1990).

Good road cut exposures of the "board beds" unit of the Entrada Sandstone are found along Rim Rock Drive between Artists Point and Coke Ovens Overlook.

The "board beds" unit consists of 60 to $70 \%$ interbedded sandstone and 30 to $40 \%$ mudstone. Sandstone is very pale orange to very light gray, white, and pinkish gray, very fine to fine grained, moderately to well sorted, intensely mottled by bioturbation, and calcareous. The map unit is thin to thick bedded and has slabby to blocky weathering. Stratification is rare and consists of discontinuous, wispy horizontal lamination and smallscale sets of tabular-tangential cross-lamination of grain flow and wind ripple structures. Southwest of No Thoroughfare Canyon, sandstone beds locally contain gray petroleum residue (dead oil). 
Mudstone is reddish brown to grayish red, thickly to thinly laminated, flaggy to fissile weathering and contains siltstone and sandy siltstone, which are typically bioturbated.

The base of the unit is defined as the top of the orange-pink, cross-bedded Slick Rock Member (Jes) of the Entrada. The thickness of the "board beds" unit is about $13 \mathrm{~m}$ along Upper Monument Canyon Trail (Cole and others, 1999).

Jes Slick Rock Member-The Slick Rock Member of the Entrada Sandstone forms a conspicuous paleorange, ribbon-like cliff or rounded bench that is almost totally free of vegetation below the white cap of the "board beds" unit.

The Slick Rock Member was deposited in a coastal eolian setting. Dunes were probably not large and had maximum heights of between 10 and $20 \mathrm{~m}$. Sand transport was generally toward the south (Kocurek and Dott, 1983, Peterson, 1988). Wet sand flats, which were related to high water tables and interdune areas, were commonly associated with dunes. An analog for the Slick Rock eolian system can be found in Baja California, Mexico, at Guerrero Negro (Fryberger and others, 1990).

One of the best places to observe the Slick Rock Member of the Entrada Sandstone is the isolated hill by the north side of the roadway about 400 meters west of the Red Canyon Overlook on the north side of Rim Rock Drive.

The map unit consists almost entirely (99\%) of cross-bedded sandstone. The sandstone is orange pink to pale reddish orange, very fine to fine grained, moderately to well sorted, commonly mottled by bioturbation, and calcareous. The map unit is very thinly to very thickly bedded, and has slabby to blocky weathering. Cementation is weak. Stratification, when present, consists of small- to large-scale sets of trough, tabular-tangential, tabular-planar, and wedge-planar crossstratification, as well as discontinuous, wispy horizontal lamination structures. Cross-strata sets are mainly composed of wind-ripple lamination; grain-flow lamination is rare. Bioturbation increases upward and is commonly associated with first-order bounding surfaces.

This member rests on the reddish-orange, thinly bedded sandstone of the Kayenta Formation. The thickness of the Slick Rock Member is $34 \mathrm{~m}$ along Upper Monument Canyon Trail (Cole and others, 1999).

Wanakah Formation and Entrada Sandstone, undivided (Middle Jurassic) - These undivided units are shown in cross sections only.
Kayenta Formation (Lower Jurassic; Pliensbachian)-The Kayenta Formation commonly forms resistant ledges above the cliff-forming Wingate Sandstone (Jwg) and also forms cliffs in several areas. Sandstone is present throughout the Kayenta, whereas conglomerate and mudstone are found mainly in the upper half.

The formation was deposited by high-energy braided-river systems. Sediment transport directions were to the west-northwest. Modern rivers draining the Rocky Mountains, such as the parts of the South Platte and Rio Grande Rivers that are in the plains, are good analogs for the depositional systems of the Kayenta Formation.

The ledge formed by the Kayenta Formation is followed by Rim Rock Drive in many areas; the Kayenta is particularly well exposed in road cuts south of the Monument Headquarters and above the tunnels uphill from the West Entrance of the Monument.

The Kayenta consists of 80 to $90 \%$ sandstone, 0 to $10 \%$ conglomerate, and 0 to $10 \%$ mudstone; the unit is well defined by Peterson (1994). Sandstone is typically reddish orange, grayish orange pink, light greenish gray, or white, fine to medium grained, moderately to well sorted, and cemented by a mixture of carbonate and quartz. The sandstone is thin to very thinly bedded and has slabby bedding. Sandstone sequences in the Kayenta contain numerous amalgamated scour surfaces that commonly have lag gravels consisting of mudstone clasts.

Conglomerate is found in channel-form sequences composed of granule- to cobble-size clasts of reddish-orange mudstone in a matrix of medium-grained, moderately sorted, light-greenish-gray sandstone; clasts are typically graded.

Mudstone consists of reddish-brown to grayish-red, thinly laminated, fissile-weathering, moderately to well-sorted siltstone and sandy siltstone; mudstone may be locally bioturbated.

Stratification is well developed in the Kayenta Formation and consists of small- to medium-scale sets of low-angle, even-parallel lamination, tabular-tangential cross-stratification, and trough cross-stratification; streaming and parting lineations are also common. The base of the Kayenta Formation is marked by the sharp break from small- to medium-scale cross-beds of siliceously cemented sandstone and mudstone to the more massive, large-scale sets of cross-stratification of the sandstone of the Wingate Sandstone. The Kayenta Formation is about $23.5 \mathrm{~m}$ thick along Upper Monument Canyon Trail (Cole and others, 1999). 


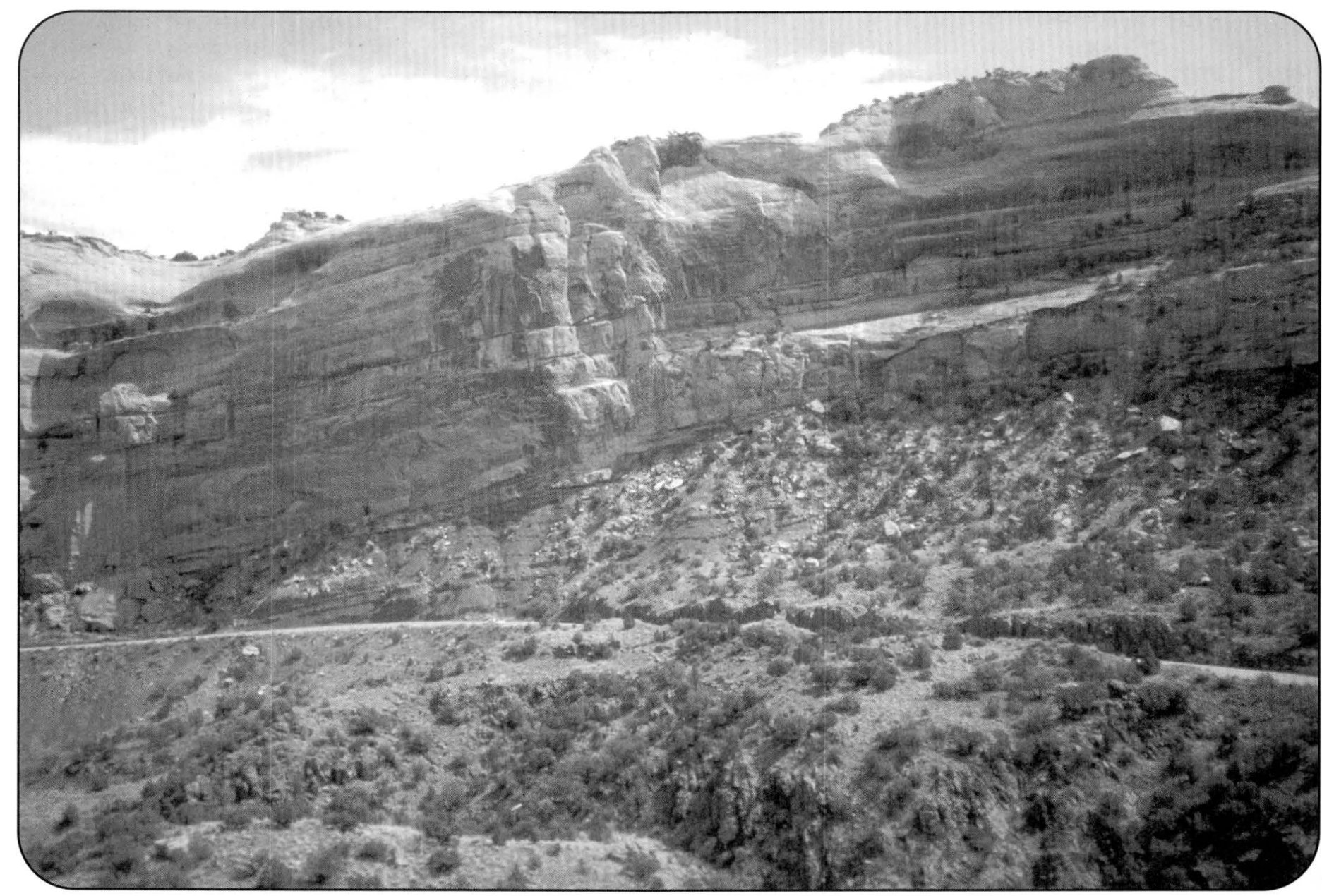

View to the east in Fruita Canyon. The strata in the monoclinal fold dip to the northeast and show the Proterozoic basement rocks overlain by the Chinle Formation and the Wingate Sandstone. Photograph by R.B. Scott, 1998.

Jwek Wanakah Formation and Entrada Sandstone (Middle Jurassic) and Kayenta Formation (Lower Jurassic), undivided-At localities along the mountain front where these steeply dipping, thin map units are exposed, the units are undivided.

Jwg Wingate Sandstone (Lower Jurassic; Pliensbachian? and Hettangian)-The Wingate Sandstone typically forms 100-m-high, reddish-orange cliffs and monuments that give the Colorado National Monument its most spectacular scenery.

The map unit was deposited in an eolian setting that was on the northeast margin of a large dune area, or erg, that occupied most of the Four Corners area in Late Triassic and Early Jurassic time (Peterson, 1994). During periods of aridity, Wingate dunes were probably 30 to $45 \mathrm{~m}$ high, and they migrated towards the south-southeast. Smaller dune complexes, wet sand flats signifying high water tables, and interdune areas were most prevalent during more humid climatic conditions. The largest dune deposits are found in the upper half of the Wingate. An analog for the Wingate dune complex can be found in the modern-day Sahara Desert of North Africa.
Good road-cut exposures of the Wingate Sandstone can be reached from the West Entrance of the Monument between the Chinle Formation ( $\mathrm{kc}$ ) and the tunnels.

The Wingate consists of about $95 \%$ sandstone and about 5\% mudstone; the unit is well defined by Peterson (1994). Sandstone is typically orange pink to reddish orange, very fine to fine grained, moderately to well sorted, calcareous, well stratified, and partly mottled and bioturbated by roots and burrows. The map unit is thinly to very thickly bedded and has slabby to blocky weathering. Stratification, when present, consists of small- to very large scale sets of even-parallel horizontal lamination, discontinuous even-parallel lamination, tabular-tangential cross-stratification, tabular-planar cross-stratification, wedge-planar cross-stratification, and trough cross-stratification. Wind-ripple lamination dominates the horizontal stratification sets, whereas wind-ripple lamination and grain-flow lamination characterize most large-scale sets of cross-stratification.

Mudstone intervals are dominated by siltstone and sandy siltstone, which are typically 
light brown to light reddish brown and reddish brown, thickly to thinly laminated, flaggy to fissile weathering, and generally mottled and bioturbated by roots(?). Stratification in mudstone is sparse, usually consisting of discontinuous horizontal lamination, wispy lamination, and rare current-ripple lamination.

In the map area, at least nine first-order bounding surfaces with associated mudstone interdune deposits are found in the Wingate, suggesting that it was deposited by a series of dune complexes, or draas, that fluctuated in size and shape in accordance with climatic variations. The thickness of the map unit is $100 \mathrm{~m}$ along Upper Monument Canyon Trail (Cole and others, 1999).

Chinle Formation (Upper Triassic; Norian and Carnian)-The Chinle Formation forms distinctive red slopes below the towering cliffs of Wingate Sandstone (Jwg) and above the great angular unconformity on dark Proterozoic basement rocks. Excellent exposures of the Chinle can be seen in the road cut in Fruita Canyon.

Sedimentologic characteristics of the Chinle suggest deposition in a densely vegetated flood plain or mud flat, containing localized shallow ponds and small, shallow, sinuous streams. Watertable fluctuations were common during deposition. Similar environments exist today in subtropical to tropical areas of South America and Africa.

The Chinle consists of interbedded 80 to $90 \%$ mudstone, 0 to $10 \%$ sandstone, 0 to $5 \%$ sandy conglomerate, and 0 to $5 \%$ limestone; the unit is well defined by Dubiel (1994). Mudstone consists of reddish-brown to reddish-orange and grayishpurple, thickly to thinly laminated, flaggy to fissile and nodular-weathering, calcareous to very calcareous, mottled, bioturbated, silty claystone, clayey siltstone, and sandy siltstone. Carbonate nodules (rhizocretions?), root traces, and burrows (crayfish?) are common.

Sandstone occurs as small, channel-form bodies that are reddish orange to grayish red-purple, thin to medium bedded, slabby weathering, fine to very coarse grained, and very poorly sorted. Sandstone commonly contains conglomeratic mudchips. Sedimentary structures are poorly developed and consist of cross-stratification, ripple-stratification, and horizontal lamination.

Conglomerate also forms channel-shaped bodies that are reddish orange to grayish red-purple, medium to thick bedded, slabby to blocky weathering, calcareous, very poorly sorted, and sandy to silty. Clasts are normally graded, consisting of pebble- to cobble-size mudstone and reworked carbonate nodules.
Limestone is reddish orange, very thin to medium bedded, slabby weathering, sandy to silty, and typically mottled and bioturbated. Some limestone beds have $1-$ to $5-\mathrm{cm}$-thick stromatolitic (algal?) structures.

The map unit is about $27 \mathrm{~m}$ thick along Upper Monument Canyon Trail (Cole and others, 1999).

YI Lamprophyre dikes (Middle Proterozoic)-Lamprophyre dikes are slightly altered, thin, dark-greenish-gray to greenish-black dikes.

One of these dikes can be visited by following No Thoroughfare Canyon trail upstream from Devils Kitchen about $500 \mathrm{~m}$ to a major drainage junction. Follow the left drainage about $250 \mathrm{~m}$ to the locality where the dark dike crosses the drainage.

The rock contains phenocrysts of biotite, hornblende, and pyroxene in a fine-grained matrix. Dikes are 2 to $3 \mathrm{~m}$ thick and are present in the northeastern part of No Thoroughfare Canyon and at the junction of Red and Columbus Canyons. The dikes are subparallel and dip to the southeast at 50 to $73^{\circ}$. The lamprophyre dike in No Thoroughfare Canyon was dated at about 1,400 Ma by the ${ }^{40} \mathrm{Ar} /{ }^{39}$ Ar method (M.J. Kunk, written commun., U.S. Geological Survey, 2000).

Meta-igneous gneiss (Early Proterozoic)-Metaigneous gneiss is metamorphosed granite that contains minor xenoliths of host rock and is exposed chiefly in the eastern part of Ute Canyon. Metaigneous bodies in and near Ute, Red, Columbus, and Gold Star Canyons are probably part of a single pluton, here called the Ute Canyon stock.

The best access to the meta-igneous gneiss is found by following the lower trail head of Liberty Cap trail to the junction with Ute Canyon trail (not shown on map) below Liberty Cap. From there, non-weathered exposures can be found by following Ute Canyon trail about $400 \mathrm{~m}$ upstream to stream crossings on the gneiss.

The meta-igneous gneiss is pinkish gray to medium gray, coarse grained, contains very coarse grained relict igneous phenocrysts of subhedral to euhedral alkali feldspar, and has a penetrative, but weakly to moderately developed, schistosity that is defined by aligned biotite. The xenoliths, which locally form 5 to $10 \%$ of the rock, consist of the dark-colored part of the migmatitic meta-sedimentary host rock and range from 0.1 to $3 \mathrm{~m}$ wide. The meta-igneous gneiss contains 20 to $40 \%$ anhedral quartz, 20 to $40 \%$ subhedral biotite, 10 to $30 \%$ euhedral, twinned, relict phenocrysts of alkali feldspar 1 to $4 \mathrm{~cm}$ long, and 10 to $20 \%$ subhedral plagioclase. During alteration and weathering, quartz grains were coated by a red hematitic stain and some of the biotite was altered to chlorite. 
The age of emplacement of the igneous body is estimated to be 1,721 \pm 14 Ma based on the preliminary discordant $U / P b$ zircon date (sample Ute 1, D.M. Unruh, unpub. written commun., U.S. Geological Survey, 1999) of the meta-igneous gneiss collected from the pluton in Ute Canyon. Nearly vertical contacts with the surrounding migmatitic meta-sedimentary gneiss $(\mathrm{Xm})$ country rock are poorly exposed but appear to be discordant with structures in that country rock. The lower contact of the meta-igneous gneiss is not exposed. The upper part of the meta-igneous body has been removed by erosion and is overlain by the Chinle Formation ( $\mathrm{kc}$ ).

\section{Xm Migmatitic meta-sedimentary rocks (Early Protero-} zoic)—The migmatitic meta-sedimentary rocks consist of a complexly folded mixture of dark schist and light migmatitic pegmatite found in the bottoms of most of the canyons at the Monument.

Good exposures of the migmatitic meta-sedimentary rocks can be reached by trails (not shown on map) into either the North Entrance or the East Entrance to Monument Canyon. The freshest exposures are in the deepest drainages off the trails.

The sedimentary rock protolith probably included graywacke, arkose, lithic arkose, subarkose, and some shale. Meta-sedimentary rocks include $65 \%$ schist, 35\% migmatitic pegmatite, and sparse boudins of calc-silicate rock. The map unit also includes a minor amount of post-metamorphic, tourmaline-bearing, pegmatite dikes.

Medium- to high-grade amphibolite metamorphism partially melted the original graywacke to arkosic sedimentary rocks, producing (1) unmelted masses of higher-melting-temperature ferromagnesian minerals (melanosome) that formed the schist and (2) a melt that crystallized to form the lower-temperature-melting quartz- and feldspar-bearing pegmatite (leucosome)

The schist is a mixture of streaky light-gray to dark-gray and pinkish-gray micaceous rock that

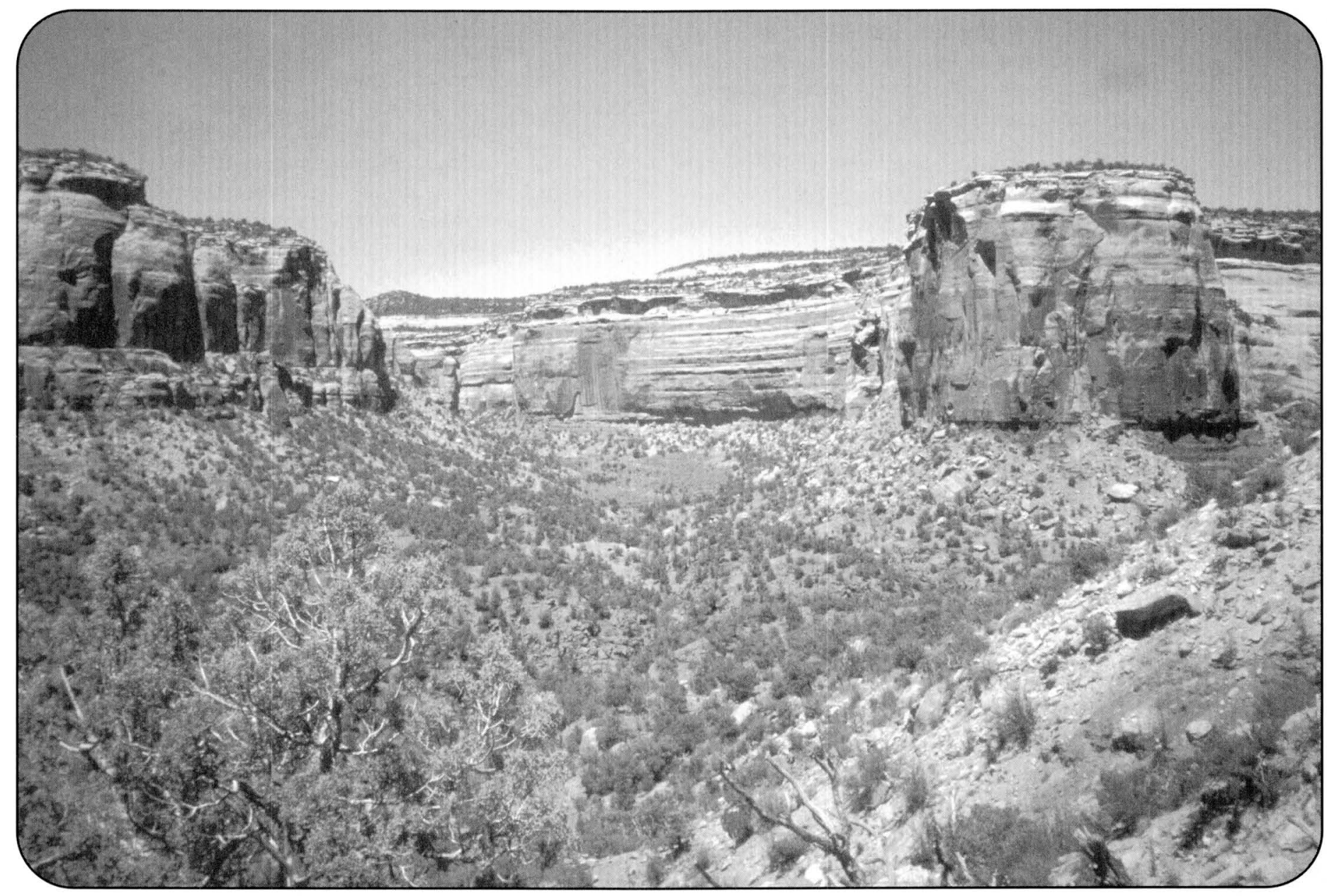

Good exposures of the migmatitic meta-sedimentary rocks are seen at the base of the Chinle-Wingate cliffs. View to the northwest at the right-angle bend in Ute Canyon. Photograph by R.B. Scott, 1998. 
contains 10 to $100 \%$ biotite, 0 to $85 \%$ quartz, 0 to $40 \%$ plagioclase, 0 to $25 \%$ alkali feldspar, 0 to $10 \%$ muscovite, 0 to $10 \%$ muscovite pseudomorphs after sillimanite, and 0 to $10 \%$ garnet. The schist has been deformed during metamorphism to create tabular, discontinuous zones of dark, well-foliated, fine- to medium-grained rock that typically has pod-shaped masses and tight elliptical to isoclinal folds. Some of the schist contains porphyroblasts of muscovite, garnet, and (or) muscovite pseudomorphs after sillimanite(?), which may contain traces of sillimanite.

The calc-silicate rock is greenish white to greenish brown and fine grained. It consists of pods, or boudins, that contain 40 to $70 \%$ epidote, 20 to $50 \%$ quartz, and 1 to $10 \%$ garnet.

Migmatitic pegmatites are pinkish gray to pinkish white, are coarse grained $(1-3 \mathrm{~cm})$, and contain 20 to $80 \%$ alkali feldspar, 15 to $80 \%$ quartz, 0 to $10 \%$ biotite, 0 to $2 \%$ garnet, and 0 to $3 \%$ muscovite. Deformation during metamorphism has created pinch-and-swell, ptygmatic, commonly symmetrical, elliptical, and tight to isoclinal folds in the pegmatitic layers that are commonly a few millimeters to $10 \mathrm{~cm}$ wide; however, some sheetlike dikes are as much as $3 \mathrm{~m}$ wide.

The post-metamorphic pegmatite dikes are distinctly different from migmatitic pegmatites in that the post-metamorphic pegmatites intrude all the metamorphic rock types described above and are less deformed than the host rock. Post-metamorphic pegmatites form only 2- to 3-m-wide dikes and contain coarse- to very coarse grained minerals that consist of 35 to $85 \%$ alkali feldspar, 10 to $20 \%$ quartz, 0 to $10 \%$ plagioclase, 0 to $10 \%$ biotite, 0 to $5 \%$ muscovite, and 0 to $5 \%$ tourmaline. These dikes probably are comagmatic with the Vernal Mesa Quartz Monzonite.

The preliminary discordant $U / P b$ zircon date (obtained from sample NT11C, D.M. Unruh, unpub. written commun., U.S. Geological Survey, 1999) of the schistose part of the meta-sedimentary rocks is $1,741 \pm 11 \mathrm{Ma}$; it is not clear whether the date represents the age of old rocks that were eroded to produce the sediments or the age of metamorphism. However, the short 20-m.y. interval between the dates for the intrusive meta-igneous gneiss (Xi) and the meta-sedimentary country rocks suggests that the 1,741-Ma date is the age of metamorphism.

\section{Selected Stratigraphic Topics}

Alluvial fans. In semiarid environments like that of the map area, ephemeral streams and debris flows commonly deposit gravelly sediment in alluvial fans along steep mountain and plateau fronts. Alluvial fans are present in two depositional settings in the map area: (1) A few alluvial fans presumably formed where steep-gradient, ephemeral streams deposited gravelly sediment along the northeast front of the Uncompahgre Plateau. However, these presumed fans were so modified by overlying eolian sand and sheetwash deposits (Qse) that fanshaped landforms are no longer recognizable. Therefore, these presumed fans are called younger alluvial-slope deposits (Qasy) and older alluvial-slope deposits (Qaso). (2) A few small Holocene young fan-alluvium and debris-flow deposits (Qfy) formed on the flood plain of the Colorado River. Young fanalluvium and debris-flow deposits are not common in the map area because some of those deposited on the flood plain of the Colorado River have been removed by the river.

Bedrock contacts. In the process of mapping the bedrock geology of Colorado National Monument and surrounding areas, stratigraphic horizons were selected that ensured that unit boundaries were readily mappable. Therefore, mappable stratigraphic horizons do not necessarily follow stratigraphic breaks defined by microfossil evidence or by detailed stratigraphic information such as paleosols that are only locally present because mapping by such features would be impractical.

The base of the Mancos Shale $(\mathrm{Km})$ was mapped at the base of the nearly continuous dark fissile shale above the uppermost prominent set of thin sandstone beds and carbonaceous interbeds of the Dakota Formation (Kd). Only the lowest $20 \mathrm{~m}$ of the Mancos Shale are exposed in the map area. These strata are equivalent to the Tununk Member of the Mancos Shale recognized in Utah (Fouch and others, 1983; Cole, 1987). Although the age of the Mancos Shale extends from Campanian to Cenomanian Ages (Young, 1959) in the Grand Valley area, only the lowermost Mancos is exposed in the map area and the age of these strata probably represents parts of Turonian and Cenomanian Ages (Fouch, 1983).

The contact between the Dakota Formation (Kd) and the underlying Burro Canyon Formation was defined arbitrarily as the base of the lowest carbonaceous mudstone above the Burro Canyon Formation (Kb). According to William A. Cobban (U.S. Geological Survey, oral commun., 1999), the upper part of the Dakota contains Cenomanian fauna near Delta, Colo., $60 \mathrm{~km}$ to the southeast of the map area, and the lower Dakota is probably Albian near the map area (Table 3).

The base of the Burro Canyon Formation rests on the K-1 (basal Cretaceous) unconformity (Peterson, 1994; Peterson and Turner, 1998) above the Brushy Basin Member of the Morrison Formation (Jmb), but that unconformity was impractical to map because it has been defined by microfossils and a poorly exposed paleosol. Therefore, the base of the Burro Canyon was arbitrarily defined as the lowest thick sandstone or conglomerate bed above the mudstone of the Brushy Basin Member (Jmb). As a result, an undetermined interval of lowermost Burro 
Canyon mudstone beds above the unconformity may have been included in the Brushy Basin (Aubrey, 1998). Because of the discontinuous and lenticular character of the sandstone and conglomerate beds in the Burro Canyon, the basal contact and the thickness of the rock unit are somewhat irregular. The Burro Canyon Formation is Albian and Aptian Age according to palynological evidence (Craig, 1981).

Contacts between the Morrison Formation members were located at horizons that could be followed readily on aerial photographs and easily located in the field. The Brushy Basin Member of the Morrison Formation (Jmb) rests disconformably above the Salt Wash Member (Jms) (unnamed unconformity; R.G. Young, oral commun., Grand Junction, Colo., 1999). Single-crystal, ${ }^{40} \mathrm{Ar} /{ }^{39} \mathrm{Ar}$ ages of feldspars from the Brushy Basin Member indicate that this member is probably Tithonian and Kimmeridgian (Kowallis and others, 1991; Kowallis and others, 1998). The contact between the two members was defined as the top of the highest thick sandstone of the Salt Wash below the mudstone beds of the Brushy Basin. As the overlying Brushy Basin Member (Jmb) was assigned to the Tithonian and Kimmeridgian Ages (Kowallis and others, 1991; Kowallis and others, 1998) and the underlying Tidwell Member (Jmt) was assigned to Kimmeridgian and latest Oxfordian Ages (Kowallis and others, 1998), the Salt Wash is restricted to the Kimmeridgian. For mapping purposes, the upper contact of the Tidwell Member (Jmt) was placed at the top of the uppermost major limestone bed of the Tidwell below the thick sandstone intervals of the Salt Wash Member. These limestone and sandstone intervals are discontinuous and lenticular, and therefore this contact and thicknesses of adjacent units are irregular. Anderson and Lucas (1998) consider the strata below the Salt Wash Member southwest of the map area to be the Summerville Formation based on thin parallel-bedded gypsiferous strata typical of the Summerville Formation. The absence of this distinctive rock type in the map unit indicates that the term "Tidwell Member" of the Morrison Formation should be retained in the map area. The lowermost sandstone package that defines the base of the Tidwell is informally called "A" bed and rests on the J-5 unconformity (Pipiringos and O'Sullivan, 1978) above the distinctive green-over-red mudstone of the Wanakah Formation. O'Sullivan (1992) indicated that the age of the Tidwell is Kimmeridgian, but subsequent ${ }^{40} \mathrm{Ar} /{ }^{39} \mathrm{Ar}$ sanidine dating suggests that the Tidwell is Kimmeridgian to latest Oxfordian (Kowallis and others, 1998).

The Wanakah Formation (Jw) was previously called the Summerville Formation in Colorado National Monument (Lohman, 1963, 1981). Although stratigraphic correlations by O'Sullivan $(1980,1992)$ suggest that the Summerville does not exist in western Colorado, more recent work of Anderson and Lucas (1998) south and west of the map area proposed that the name Summerville Formation is appropriate for strata below the Salt Wash Member. It is unclear whether the Summerville Formation as defined by Anderson and Lucas includes the Wana$\mathrm{kah}$, and here the Wanakah nomenclature is retained. The base of the Wanakah Formation is readily recognized in the field or on aerial photographs as the base of the distinctive red lower part of the map unit. The Wanakah is assigned to the Callovian Age (O'Sullivan, 1992; Peterson, 1994).

The prominent white cap of the Entrada Sandstone above the Slick Rock Member (Jes) differs significantly from the Moab Member of the Entrada Sandstone present southwest of the map area. The Moab Member does not contain thin to thick, light-colored beds of sandstone that only rarely display smallscale wind ripple structures and does not commonly include interbeds of reddish-brown to grayish-red mudstone, both characteristic of the white cap in the map area. Therefore, the stratigraphic nomenclature of Lohman $(1963,1981)$ for this unit is not retained in this report, and an informally named "board bed" unit (Jeb) is accepted here following O'Sullivan and Pipiringos (1983) until further stratigraphic studies are performed. The Slick Rock Member of the Entrada Sandstone rests on the J-2 unconformity (Pipiringos and O'Sullivan, 1978); erosional relief on the J-2 unconformity is as much as $3 \mathrm{~m}$. The Slick Rock Member is Callovian Age (Peterson, 1998a).

The Kayenta was tentatively assigned to Pliensbachian and Sinemurian Ages by Peterson and Pipiringos (1979), then restricted by Peterson (1988b) to Pliensbachian and Sinemurian Ages, and most recently further restricted by Peterson (1994) to Pliensbachian.

The Wingate has been assigned to the Hettangian Age based on dinosaur fossils (Padian, 1989), but more recently it was expanded to Pliensbachian to Hettangian Ages by Peterson (1994).

The age of the Chinle Formation is Late Triassic (Norian and Carnian); its sedimentology and depositional history in northwestern Colorado is summarized by Dubiel (1992).

The basal contact of the Chinle Formation on Proterozoic rocks is an angular unconformity that represents a break in the rock record between about 1,400 and 230 million years ago, or about 1,170 million years.

\section{Geochronology}

In conjunction with mapping the Colorado National Monument area, several rock units have been dated by radiometric methods. A detailed explanation of the geologic setting of the dated samples, the methods used, and interpretations of the results follows. Some results are preliminary because further research is required to define which of several possible geologic events has been dated. The time of formation of crystalline rocks of the Proterozoic basement can be dated, but with difficulty, mostly because the radiometric "clock" of zircon is not necessarily reset by the degree of metamorphism of the rocks in the map area. The time of deposition of overlying Mesozoic sedimentary strata cannot be dated using radiometric techniques, and the age of many of the sandstone units cannot be determined because they are relatively nonfossiliferous. In contrast, the charcoal in Holocene valley-fill deposits is easily dated by ${ }^{14} \mathrm{C}$ methods. The geochronological results are discussed below. 


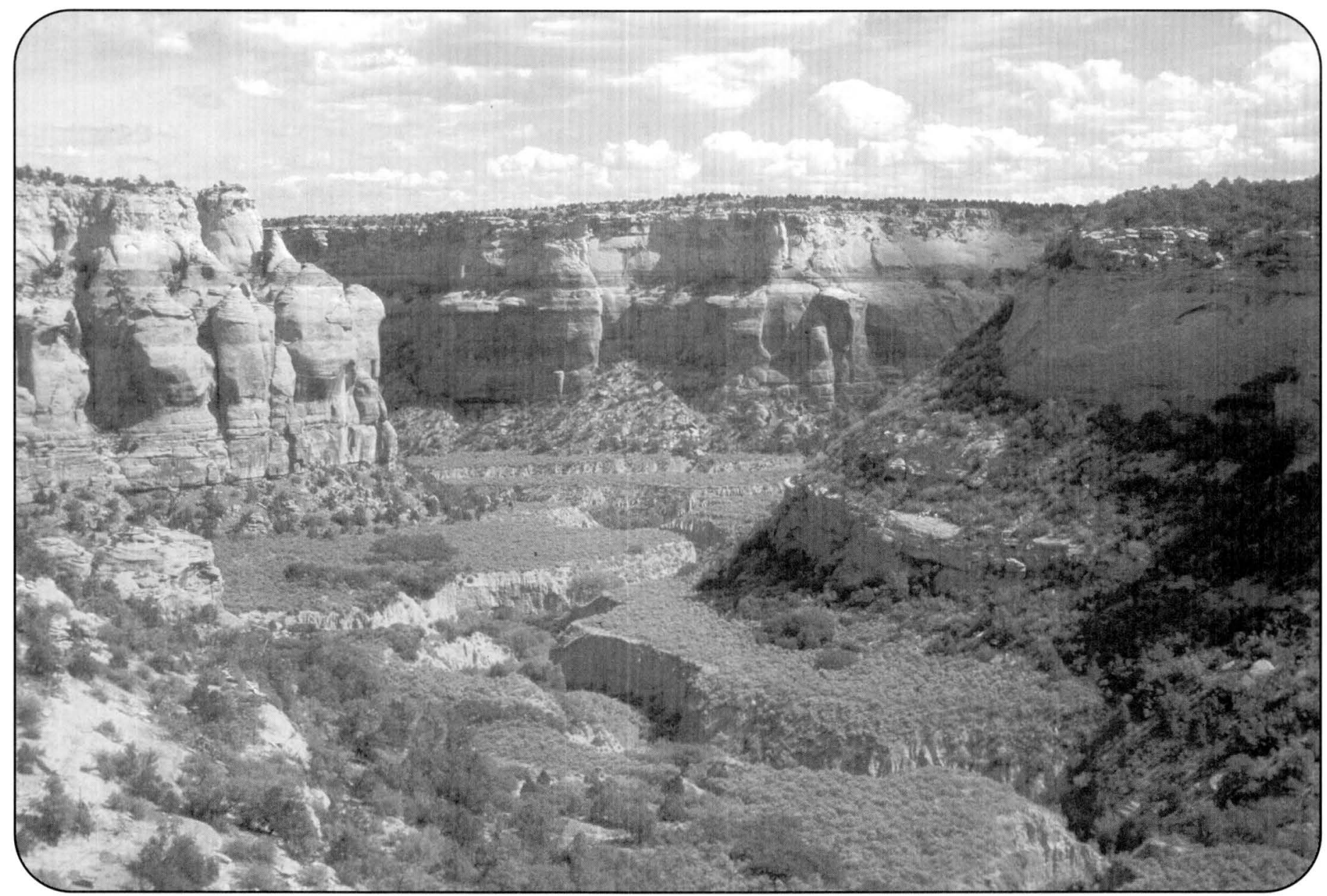

Dissected Holocene and latest Pleistocene sandy valley-fill deposits in the upper part of No Thoroughfare Canyon. View to the northeast. Photograph by W.C. Hood, 1998.

Evidence indicates that the Proterozoic rocks of Colorado National Monument either were metamorphosed from sediments derived from rocks that were formed about 1,740 Ma or were metamorphosed about 1,740 Ma. This event was quickly followed by intrusion of a stock about 1,720 Ma. Parts of the Uncompahgre Plateau and the Black Canyon of the Gunnison were then intruded by large batholith-and stock-size bodies of quartz monzonite about 1,430 Ma, although direct evidence of this intrusion was not recognized within the map area.

The preliminary discordant U/Pb zircon date (obtained from sample NT11C, D.M. Unruh, unpub. data, U.S. Geological Survey, 1999) of the schistose part of the migmatized metasedimentary rocks $(\mathrm{Xm})$ southwest of Devils Kitchen is $1,741 \pm 11 \mathrm{Ma}$. The discordant nature of the date is considered to be related to regional reheating and loss of $\mathrm{Pb}$ caused by emplacement of the 1,400-Ma Vernal Mesa Quartz Monzonite. Although the quartz monzonite is not exposed in the map area, it may be present at depth. It is unclear from either geochronological data or ambiguous petrographic evidence derived from the shapes of zircon grains whether this date represents the age of the protolith or the age of migmatization of the meta-sediments. This date appears to be older than the $\mathrm{Rb} / \mathrm{Sr}$ isochron age of 1,630 Ma for the feldspathic gneiss dated by Hedge and others (1968) south of the map area on the Uncompahgre Plateau, but the large uncertainty $( \pm 130 \mathrm{Ma}$ ) related to the low $\mathrm{Rb} / \mathrm{Sr}$ ratio of the feldspathic gneiss allows the two dates to be compatible. The post-metamorphic pegmatitic dikes that cut the 1,700-Ma migmatitic rocks of the Monument area are considered to be comagmatic with the Vernal Mesa Quartz Monzonite.

In the Monument area, the age of emplacement of the Early Proterozoic meta-igneous gneiss (Xi) of the Ute Canyon stock (west of the mouth of Ute Canyon) has been estimated to be $1,721 \pm 14 \mathrm{Ma}$ based on the preliminary discordant $U / P b$ date (sample Ute 1, D.M. Unruh, unpub. data, U.S. Geological Survey, 1999). The discordant nature of this date may also be related to $\mathrm{Pb}$ loss caused by regional heating following intrusion of the Vernal Mesa Quartz Monzonite. This date may be slightly older than the $\mathrm{Rb} / \mathrm{Sr}$ isochron age of $1,670 \pm 40 \mathrm{Ma}$ determined for emplacement of a gneissic granodiorite collected about $40 \mathrm{~km}$ west of the map area on the Uncompahgre Plateau (Hedge and others, 1968). However, if the uncertainty is taken into account, there is a 3-m.y. overlap in their ages.

At least two quartz monzonite batholith-size bodies intruded the region in and near the Uncompahgre Plateau more than 1,400 Ma. The Vernal Mesa Quartz Monzonite in Unaweep Canyon

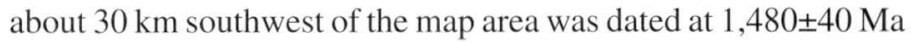
by the Rb-Srisochron method by Hedge and others (1968). A petrographically similar plutonic body in the Black Canyon of the 
Gunnison River about $80 \mathrm{~km}$ to the southeast of the map area has a similar age using the same dating method (Hansen and Peterman, 1968). The age of intrusion of the Vernal Mesa Quartz Monzonite in Unaweep Canyon has been confirmed by the concordant date of $1,433 \pm 2 \mathrm{Ma}$ using the $\mathrm{U} / \mathrm{Pb}$ method for zircon from sample UN2 (D.M. Unruh, unpub. data, U.S. Geological Survey, 1999). In the canyons just west of the map area, there is another intrusion. This stock contains large potassium feldspar phenocrysts aligned at attitudes inconsistent with the attitudes of the schistosity of the older migmatized meta-sedimentary gneiss and does not display a through-going schistosity. These relations are similar to those of the Vernal Mesa and Black Canyon intrusions and suggest that the stock may have a younger intrusive age, similar to the 1,400-Ma age of the Vernal Mesa intrusion. The undeformed pegmatite dikes in the map area may be comagmatic with this body.
Two lamprophyre dikes (Yl) cut the Proterozoic rocks, one in the northeastern part of No Thoroughfare Canyon and one in the northeastern part of Columbus Canyon. The biotite in the lamprophyre dike in No Thoroughfare Canyon (sample $\mathrm{K} 98.8 .10 \mathrm{~F}$ ) provided a preliminary ${ }^{40} \mathrm{Ar} /{ }^{39} \mathrm{Ar}$-method date of slightly less than about 1,400 Ma (M.J. Kunk, U.S. Geological Survey, unpub. data, 2000). Unrelated diabase dikes in similar Proterozoic rocks of the Black Canyon of the Gunnison about $90 \mathrm{~km}$ to the southeast of the map area were dated by the $R b / S r$ isochron method at $510 \pm 60 \mathrm{Ma}$ (Hansen and Peterman, 1968) and are much younger than the lamprophyres in Colorado National Monument.

Sandy valley-fill deposits (Qvf) that locally cover canyon floors on the Uncompahgre Plateau commonly contain significant amounts of charcoal fragments (Scott and others, 1999). Thirteen charcoal samples have been dated using ${ }^{14} \mathrm{C}$ dating

Table 4. ${ }^{14} \mathrm{C}$ laboratory values and calibrated ages for valley-fill deposits in and near the map area.

\begin{tabular}{|c|c|c|c|c|c|c|}
\hline Sample & $\begin{array}{l}\text { Depth } \\
\text { (m) }\end{array}$ & $\begin{array}{c}{ }^{14} C \text { lab value } \\
\text { (years BP) }\end{array}$ & $\begin{array}{l}\text { Calibrated age } \\
\text { (years BP) }\end{array}$ & Lab number & Latitude & Longitude \\
\hline \multicolumn{7}{|c|}{ Uppermost part of No Thoroughfare Canyon } \\
\hline \multirow[t]{3}{*}{$\mathrm{C} 2$} & 2.2 & $1,970 \pm 50$ & 1,900 & W1734 & $38^{\circ} 59.209^{\prime}$ & $108^{\circ} 41.714^{\prime}$ \\
\hline & & & 1,910 & & & \\
\hline & & & 1,920 & & & \\
\hline $\mathrm{C} 3$ & 6 & $4,870 \pm 50$ & 5,600 & W1735 & $38^{\circ} 59.218^{\prime}$ & $108^{\circ} 41.722^{\prime}$ \\
\hline \multirow[t]{6}{*}{$\mathrm{C} 4$} & 9 & $9,190 \pm 50$ & 10,250 & W1736 & $38^{\circ} 59.213^{\prime}$ & $108^{\circ} 41.754^{\prime}$ \\
\hline & & & 10,300 & & & \\
\hline & & & 10,320 & & & \\
\hline & & & 10,350 & & & \\
\hline & & & 10,360 & & & \\
\hline & \multicolumn{6}{|c|}{ Farther downstream in No Thoroughfare Canyon } \\
\hline C5 & 6 & $4,210 \pm 40$ & 4,830 & W2072 & $38^{\circ} 59.890^{\prime}$ & $108^{\circ} 41.100^{\prime}$ \\
\hline \multirow[t]{3}{*}{ C6 } & 9 & $4,470 \pm 50$ & 5,050 & W2071 & $38^{\circ} 59.890^{\prime}$ & $108^{\circ} 41.100^{\prime}$ \\
\hline & & & 5,190 & & & \\
\hline & & & 5,200 & & & \\
\hline $\mathrm{C7}$ & 19 & $5,380 \pm 50$ & 6,200 & W2442 & $38^{\circ} 59.890^{\prime}$ & $108^{\circ} 41.100^{\prime}$ \\
\hline $\mathrm{C} 8$ & 19.5 & $4,900 \pm 50$ & 5,610 & W2443 & $38^{\circ} 59.890^{\prime}$ & $108^{\circ} 41.100^{\prime}$ \\
\hline \multirow[t]{4}{*}{ C9 } & 19.8 & $5,060 \pm 60$ & 5,760 & W2444 & $38^{\circ} 59.890^{\prime}$ & $108^{\circ} 41.100^{\prime}$ \\
\hline & & & 5,830 & & & \\
\hline & & & 5,860 & & & \\
\hline & & & 5,880 & & & \\
\hline \multirow[t]{2}{*}{$\mathrm{C} 10$} & $\sim 19$ & $4,540 \pm 50$ & 5,290 & W2445 & $38^{\circ} 59.908^{\prime}$ & $108^{\circ} 41.070^{\prime}$ \\
\hline & & Below the ex & of No Thoroughfa & nyon from Col & National Mo & \\
\hline \multirow[t]{5}{*}{$\mathrm{Cl}$} & $\sim 1.6$ & $1,280 \pm 50$ & 1,180 & W1734 & $39^{\circ} 1.853^{\prime}$ & $108^{\circ} 37.520^{\prime}$ \\
\hline & & & 1,200 & & & \\
\hline & & & 1,230 & & & \\
\hline & & & 1,250 & & & \\
\hline & & & Upper & ff Red Canyon & & \\
\hline \multirow[t]{2}{*}{$\mathrm{C} 11$} & 1.5 & $2,370 \pm 40$ & 2,350 & W2073 & $39^{\circ} 1.955^{\prime}$ & $108^{\circ} 40.638^{\prime}$ \\
\hline & & & Cactus Park, 20 & outheast of the & area & \\
\hline \multirow[t]{2}{*}{$\mathrm{C} 12$} & -2 & $8,600 \pm 50$ & 9,550 & W2169 & $38^{\circ} 52.08^{\prime}$ & $108^{\circ} 29.55^{\prime}$ \\
\hline & \multicolumn{6}{|c|}{ Alcove above samples $\mathrm{C} 2$ to $\mathrm{C} 4$ on western canyon wall } \\
\hline C13 & 0.3 & $4410 \pm 40$ & 4,980 & W2074 & $38^{\circ} 58.710^{\prime}$ & $108^{\circ} 40.887^{\prime}$ \\
\hline & & & 5,030 & & & \\
\hline
\end{tabular}




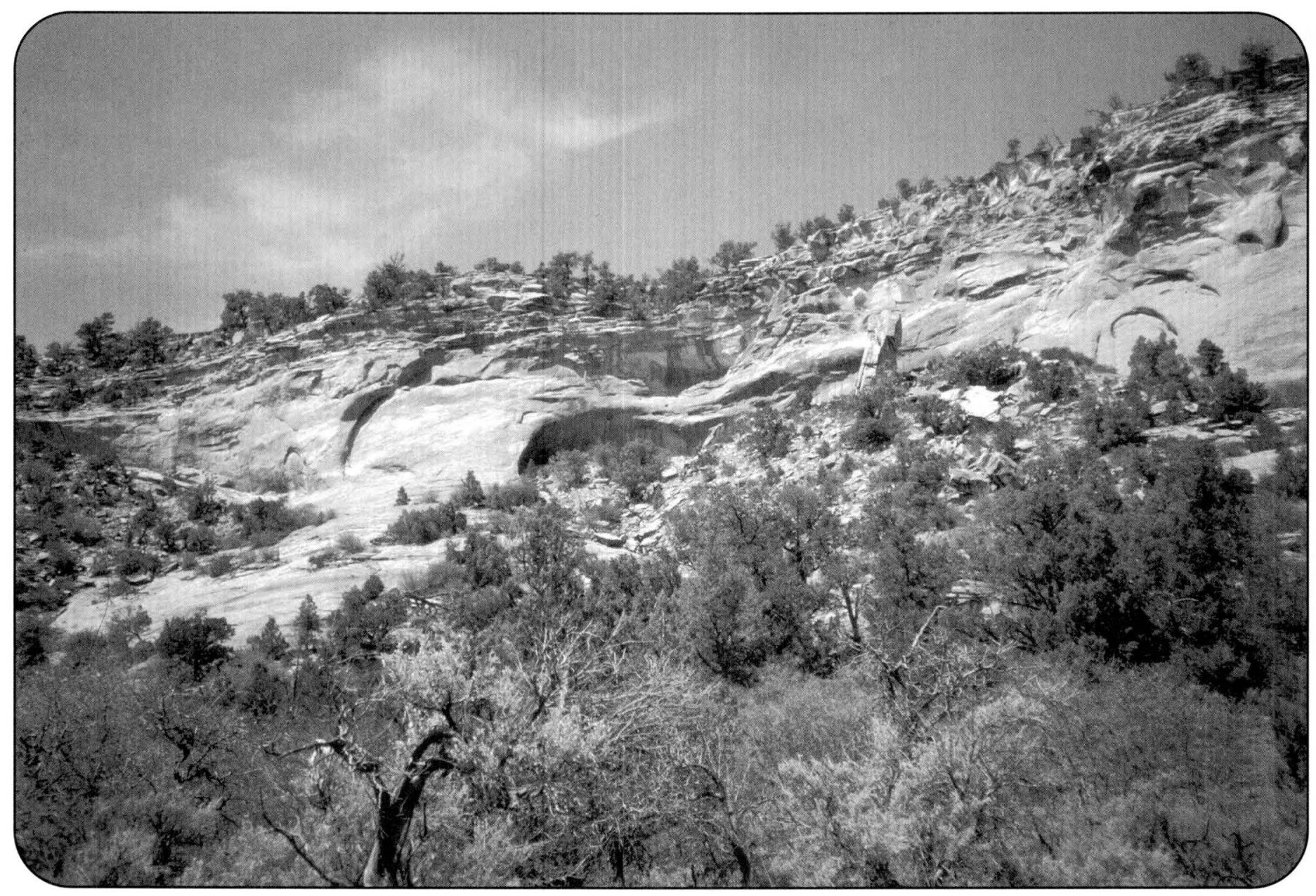

View to the southwest from the upper part of No Thoroughfare Canyon showing an alcove in the cliff of Wingate Sandstone. Photograph by R.B. Scott, 1998 .

techniques at the University of California, Berkeley, Accelerator Mass Spectrometer (analyses by J.P. McGeehin, unpub. data, U.S. Geological Survey, 1998 and 1999). These laboratory measurements (Table 4) are given in years before present (years BP), referenced to the year 1954. Because there have been fluctuations in the abundance of ${ }^{14} \mathrm{C}$ in the atmosphere in the past (related to cosmic radiation variations), each laboratory measurement can be translated into multiple calibrated ages (Stuiver and others, 1998) (Table 4). These calibrated ages still have a relatively narrow range of values and can provide approximate ages of the charcoal. Because the trees from which the charcoal came may have been piñon or juniper that had lived for several hundred years, the calibrated ages may be older by several hundred years than the time of the wildfire that produced the charcoal.

Three charcoal samples from a deep stream cut in the uppermost part of No Thoroughfare Canyon were dated. The lab value of the youngest sample (C2), collected $2.2 \mathrm{~m}$ below the top of unit Qvf, is $1,970 \pm 50$ years BP; the lab value of the next older sample (C3), collected $6 \mathrm{~m}$ below the top of the unit, is $4,870 \pm 50$ years BP; the lab value of the oldest sample (C4), collected $9 \mathrm{~m}$ below the top of the unit, is $9,190 \pm 50$ years BP. A few centimeters below sample $\mathrm{C} 3$, an artifact (stone scraper) was found, suggesting that the canyon was inhabited by ancestors of Native Americans more than about 5,600 years BP based on the calibrated age of the charcoal.

Another five samples collected about $2 \mathrm{~km}$ farther downstream in No Thoroughfare Canyon were dated. The lab value of the youngest sample (C5), collected $6 \mathrm{~m}$ below the surface, is $4,210 \pm 50$ years BP. The lab value of the next older sample (C6), collected $9 \mathrm{~m}$ below the surface, is $4,470 \pm 50$ years BP. The third sample (C7) was collected about $19 \mathrm{~m}$ below the surface and 1.2 $\mathrm{m}$ above the base of the sediments of unit Qvf, and has a lab value of 5,380 \pm 50 years BP. The lab value of the fourth sample (C8) collected at $0.7 \mathrm{~m}$ above the base of the sediments was

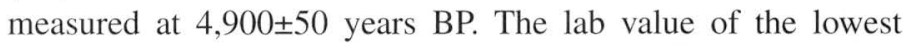
sample (C9), collected $0.4 \mathrm{~m}$ above the base, was measured at $5,060 \pm 60$ years BP. For reasons that are unclear, the ages of the lowest two samples are not consistent with the stratigraphic sequence, even when taking into account the analytical uncertainties of the dating method. Possibly, older sediments were undercut by erosion and replaced by younger sediments about 300 and 500 years later, but it is more likely that different ages of trees are involved or large variations in transport time affected the sequence. 
Sample C10 collected $60 \mathrm{~m}$ further downstream, at a depth of about $19 \mathrm{~m}$ and $1 \mathrm{~m}$ above the bedrock, has a lab value of $4,540 \pm 50$ years BP. Sample C1 collected from the lower part of No Thoroughfare Canyon at a depth of about $1.6 \mathrm{~m}$, just within the southeastern boundary of Colorado National Monument, has a lab value of $1,280 \pm 50$ years BP. Although this sample was collected from valley-fill deposits (Qvf), the exposure in a cutbank, which is overlain by eolian sand and sheetwash deposits (Qse), is too narrow to be shown on the map. Another sample (C11) collected from the upper part of Red Canyon, $1.5 \mathrm{~m}$ below the surface of a 3-m-high terrace adjacent to the drainage, has a lab value of $2,370 \pm 40$ years BP.

Sample C12, collected from similar sediments at a depth of about $2 \mathrm{~m}$ in Cactus Park, $20 \mathrm{~km}$ southeast of the map area, provided a lab value of $8,600 \pm 50$ years $\mathrm{BP}$ (and a calibrated age of about 9,550 years BP). It indicates that sediments equivalent to the valley-fill deposits were probably deposited elsewhere on the Uncompahgre Plateau also during the Holocene and latest Pleistocene.

Jack Roadifer (emeritus faculty member at Mesa State College) found a mastodon tooth in the streambed of No Thoroughfare Canyon. It is assumed that the tooth was eroded from the lower part of the valley-fill deposits. The oldest calibrated ages from sample C4 that range from 10,250 to 10,360 years BP and the presence of the tooth confirm that the oldest part of the valleyfill deposits is older than 10,000 years BP, and therefore, is late Pleistocene. The ages of the valley-fill sediments are progressively younger downstream in No Thoroughfare Canyon. This relation can be explained by a downlap depositional sequence, and it is also likely that there are numerous unconformities in this sedimentary sequence (Scott, Hood, and others, 1999).

Charcoal sample $\mathrm{C} 13$ was collected from the west wall of the upper part of No Thoroughfare Canyon from distinctly different sediments in an alcove protected from erosion. This alcove is about $45 \mathrm{~m}$ above the floor of the canyon. Careful inspection of the cliff above the alcove suggests that a large slide block of the Wingate Sandstone (Jwg) dammed the entrance of the alcove, allowing charcoal-bearing sediments to accumulate in the alcove behind the dam. Only remnants of the slide block still exist. The ${ }^{14} C$ lab value of $4,410 \pm 40$ years BP provides minimum calibrated ages of 4,980 or 5,030 years BP for the disintegration of the sandstone block.

\section{Geologic Formation of Colorado National Monument}

Over a period of about 1.7 billion years, a little longer than a third of the Earth's history, geologic processes have created the features at Colorado National Monument. These processes include volcanism in island arcs along the growing ancestral North American continental margin, high-grade metamorphism, several periods of mountain building, several periods of deep erosion, deposition of marine and non-marine sediments, more uplift, and, finally, erosion that carved the modern landforms. In the Geologic History section, we will describe the geologic processes that operated during the formation of the Monument. In the Structural and Tectonic Issues section, we will present a more detailed interpretation of the structures and tectonism that are responsible for much of the character of the Monument.

\section{Geologic History}

For well over a century, many geologists have studied the geologic history of the area around Colorado National Monument. Our study of the Monument area adds to this geologic knowledge. In the following pages we will first describe the general setting of the Monument region, then address the history of the Monument area and relate that history to features on the map of the Monument.

Colorado National Monument and adjacent areas of this map are within the Colorado Plateau, about $110 \mathrm{~km}$ west of the northeastern border of the Plateau where the Colorado River cuts through the steeply dipping strata of the Grand Hogback (Figure 1). The Colorado Plateau is an elevated, mildly folded and faulted physiographic province generally underlain by nearly flat-lying sedimentary rocks. The Colorado National Monument map area overlaps the northeastern margin of the Uncompahgre uplift, which is expressed topographically by the Uncompahgre Plateau. It forms a northwest-trending, elongate uplift on the Colorado Plateau that measures $150 \mathrm{~km}$ by $45 \mathrm{~km}$. In the northeastern part of the map area, the Uncompahgre Plateau abruptly ends with an $800 \mathrm{~m}$ drop in elevation to the level of the Redlands area, the Colorado River, and Grand Valley. This elevation change coincides with changes from nearly horizontal strata on the Uncompahgre Plateau to steeply dipping and faulted strata in a narrow zone in which strata drop nearly 600 $\mathrm{m}$. The S-shaped fold that accompanies this steeply dipping zone is called a monocline. Under the Redlands area, the northeast dip of strata decreases to $5^{\circ}$ (see sections $A-A^{\prime}$ and $B-B^{\prime}$ ). The dip of strata decreases eastward under Grand Valley to $2^{\circ}$, but then increases again to about $5^{\circ}$ in the Book Cliffs monocline under the Book Cliffs (Figure 2), based on structure contours drawn on the top of the Dakota Formation on a regional map compiled by Cashion (1973).

During the Early Proterozoic, south of the edge of the Archean North American craton in Wyoming, island arc volcanic rocks and related sediments accumulated along a convergent plate margin. Evidence of these calc-alkalic volcanic rocks and sedimentary rocks is widespread in a $500-\mathrm{km}$-wide belt of Early Proterozoic rocks in Colorado (Reed and others, 1987), including Colorado National Monument. About 1.74 billion years ago, during a period of compressive mountain building along that new continental margin, isoclinal folding, high-grade metamorphism, and partial melting converted these rocks into the migmatitic metasedimentary rocks (Xm) now so well exposed in the canyon bottoms of the Monument. Only 20 million years later ( 1.72 billion years ago), a granitic body (metaigneous gneiss, $\mathrm{Xi}$ ) intruded the area of No Thoroughfare and Ute Canyons. The granitic rock was only weakly affected by the waning phase of metamorphism and compression. About 1.4 billion years ago, two narrow, northeast-trending lamprophyre dikes (Yl) intruded the area, probably after the end of this first period of compressional mountain building.

No record of geologic events during the next 1,170 million years exists in the Monument area; this enormous break in the rock record is known as the Great Unconformity. Throughout Colorado, deep erosion of Early Proterozoic rocks removed kilometers of the overlying, less metamorphosed rocks and 


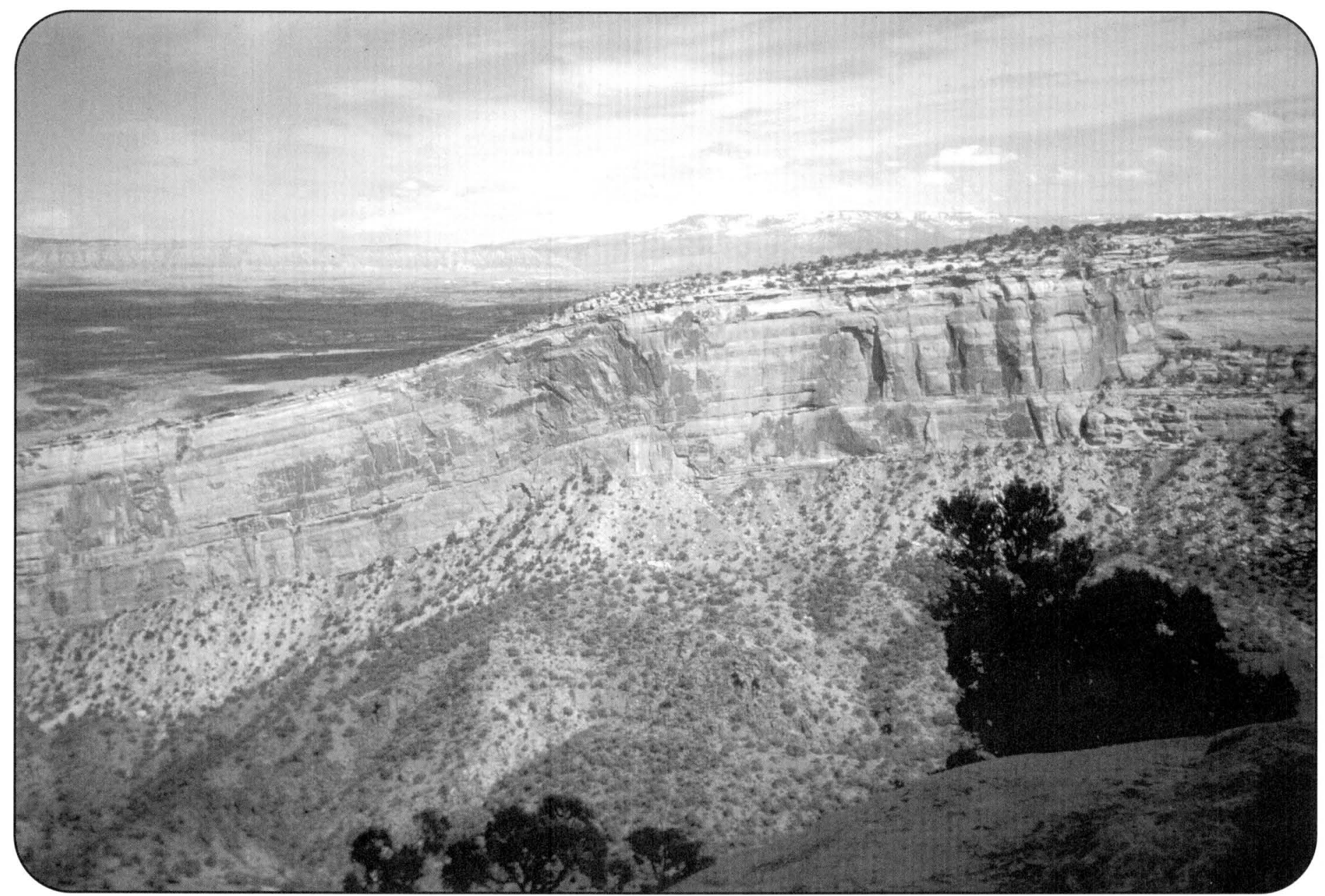

View to the east across the North Entrance of Monument Canyon. Note the hinge line between the shallow dip on the highlands on the right and steeper dips on the left. The Wingate Sandstone becomes significantly thinner on the left as it enters the monoclinal fold. Photograph by R.B. Scott, 1998.

exposed the highly metamorphosed cores of ancient mountains. During Cambrian through Mississippian time (570-320 Ma), relatively thin marine sandstone, limestone, dolomite, and shale were deposited, covering much of the North American craton.

During Pennsylvanian and Permian time (320-245 Ma), Colorado was subject to a second period of compression and uplift, which formed the Ancestral Rocky Mountain Front Range uplift and the Ancestral Uncompahgre uplift by crustal shortening on high-angle reverse and thrust faults (Ye and others, 1996). Lower Paleozoic marine rocks were eroded from the Monument area and were transported several tens of kilometers southwestward to be deposited in great thicknesses in the Paradox Basin (Figure 2). Eventually, Early Proterozoic metamorphic rocks again lay exposed in the Monument area.

Then, deposition began again. Triassic through Cretaceous sediments were deposited over Colorado, this time under largely non-marine conditions until the Late Cretaceous seas covered the area. During the Mesozoic, non-marine sandstone and shale were deposited on the Great Unconformity above the Early Proterozoic metamorphic rocks. Most of the cross-bedded sandstone was deposited in desert conditions similar to those in the modern Sahara, and shale commonly was deposited in shallow non-marine lakes. These strata were then covered by the thick marine Mancos Shale and younger non-marine sandstone and shale.

For a third time mountain building affected Colorado. The Laramide orogeny began during the Late Cretaceous (about 70 $\mathrm{Ma}$ ) and continued into middle Eocene (about $50 \mathrm{Ma}$ ). Although the Rocky Mountains experienced significant compression and uplift, farther west the Colorado Plateau experienced more subtle uplifts that caused the sedimentary strata to become folded above deep-seated, high-angle reverse faults to form monoclinal folds (Hunt, 1956a; Lohman, 1965; Stone, 1977; Miller and others, 1992; Davis, 1999). It is this style of folding and faulting that created most of the structural framework of the northeastern and southwestern margins of the Uncompahgre Plateau and Colorado National Monument.

After the Laramide, during a significant part of the Cenozoic Era, great volumes of sedimentary rocks, particularly the soft, easily eroded shales, were slowly removed from the Colorado Plateau. During periods of relative tectonic quiescence, rivers in the area tended to meander and began to carve broad valleys into areas underlain by Mancos Shale, such as Grand Valley. Regional uplift(s) in the Late Cenozoic caused the rivers to entrench their meanders into the more resistant rocks beneath the Mancos, forming the Grand Canyon, the Goosenecks of the San Juan 


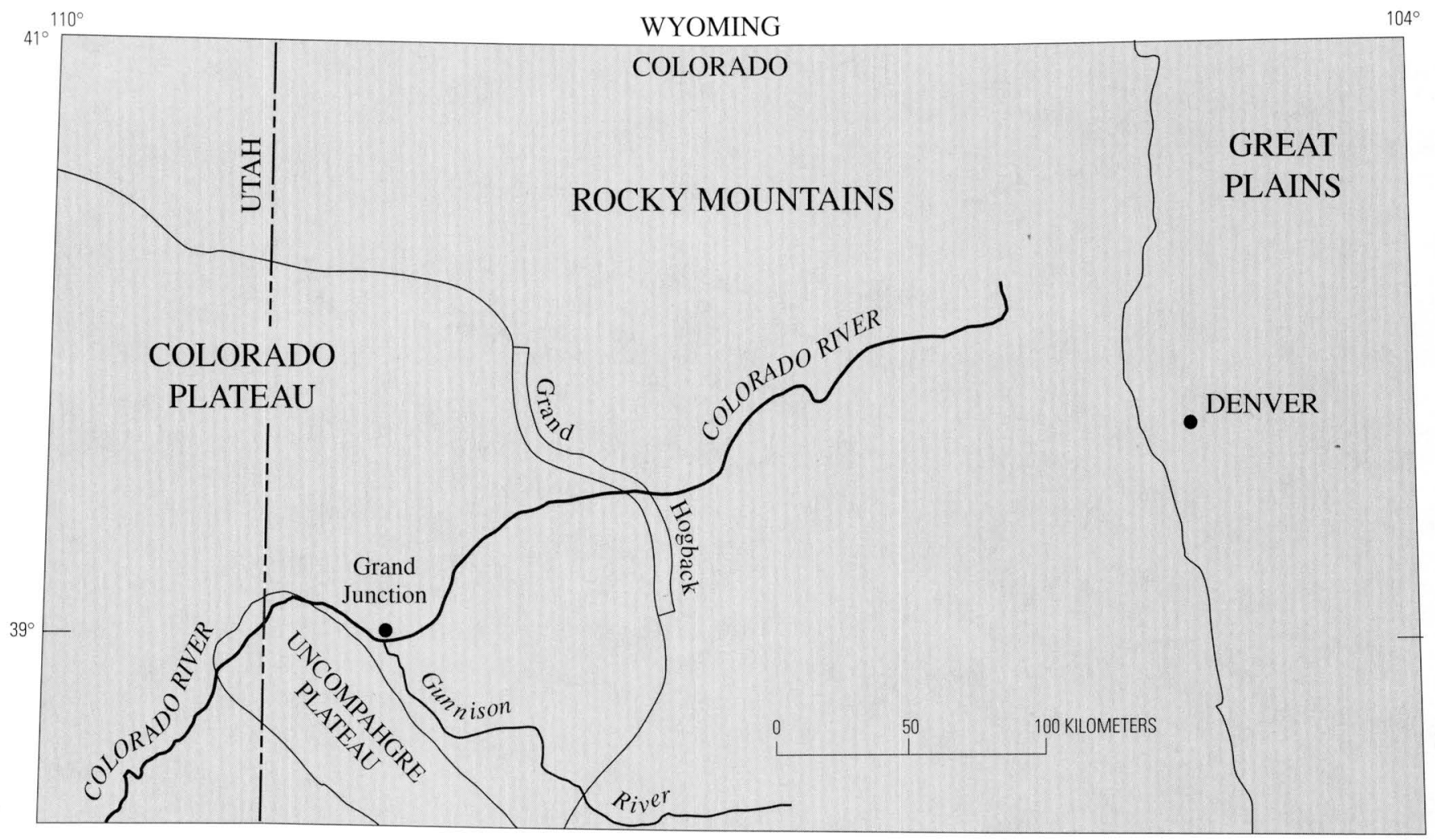

Figure 1. Regional geographic features in western Colorado and eastern Utah.

River, and Ruby and Horse Thief Canyons at the northwestern end of the Uncompahgre uplift. This process of exhumation as a result of regional uplift is continuing today, and erosion of the canyons on the northeastern edge of the Uncompahgre Plateau at Colorado National Monument is beginning to strip older, more resistant Mesozoic rocks from the Plateau. And for a fourth time, Early Proterozoic rocks are being exposed. It is this canyon-cutting process that today is actively creating the magnificent scenery at Colorado National Monument.

\section{Structural and Tectonic Issues}

In this section, we address more detailed scientific issues. Because evidence of the character and timing of uplift of the Uncompahgre Plateau is subtle, many puzzles and controversies remain unresolved. Therefore, this section is not an attempt to resolve issues, but rather to highlight them. Although the text is more technical than the preceding discussion of the geologic history, the Glossary should make it possible for non-geologists to follow issues.

\section{Interpretation of Structures At Colorado National Monument}

First we addresses the nature of faulting associated with Laramide uplift. As stated above, monoclinal folds in the Mesozoic sedimentary rocks above high-angle reverse faults in basement rocks are considered to be characteristic of Laramide deformation (Hunt, 1956a; Lohman, 1965; Stone, 1977; Miller and others, 1992; Davis, 1999). In contrast, normal faults are commonly associated with post-Laramide extension. Some areas on the Uncompahgre Plateau margins display only high-angle reverse faults, other areas display both reverse and normal faults, and one area displays only normal faults. The question arises, does the presence of normal faults suggest that some of the uplift or deformation of the Uncompahgre is post-Laramide?

All major faults on the northeastern margin of the Uncompahgre Plateau in the map area are clearly high-angle reverse faults, and therefore, they are consistent with compressional features associated with the Laramide. However, elsewhere on the northeast margin, both normal and reverse faults are generally present (Heyman, 1983; Heyman and others, 1986). The geometric relations between these reverse and normal faults suggests that the normal faults are secondary and antithetic to major reverse faults, and therefore, both types of faults were probably formed together during the Laramide.

On most of the southwest margin of the Plateau, only highangle reverse faults of Laramide age deformed Mesozoic strata (White and Jacobson, 1983; Heyman and others, 1986). However, on the northwest part of the southwest margin of the Plateau, major faults that affected Mesozoic strata are all normal faults (Williams, 1964; Case, 1966). No major high-angle reverse fault is recognized in the subsurface (White and Jacobson, 1983; Heyman and others, 1986). At this locality, Williams (1964) uses structure contours drawn on the base of the Dakota Formation to demonstrate as much as $685 \mathrm{~m}$ of structural relief between the Paradox basin and the Uncompahgre Plateau on normal faults and monoclinal folds. The possibility that these 


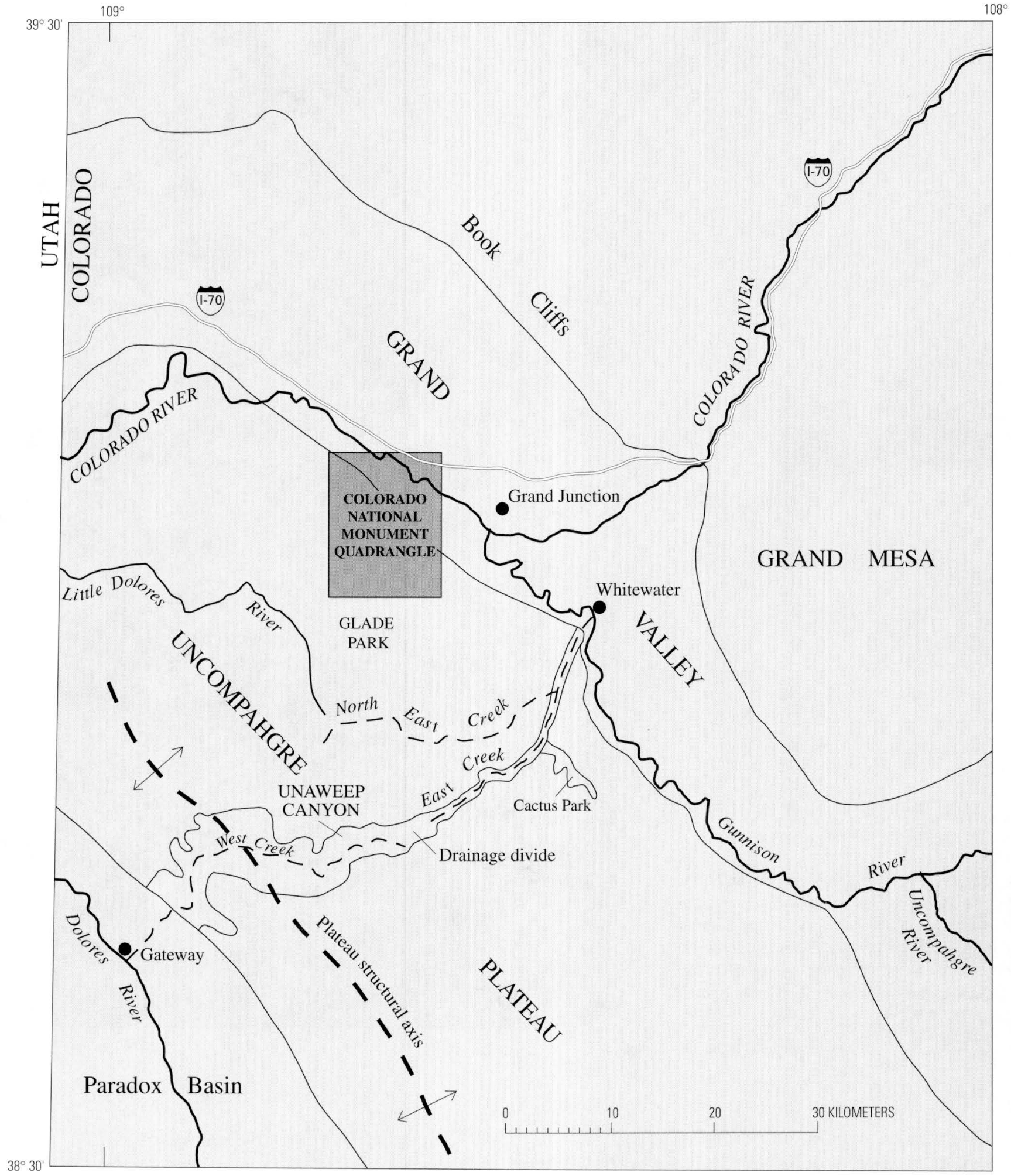

Figure 2. Geographic features near the map area.

large structures are related to post-Laramide extension rather than to Laramide compression is rejected because the elevations of stratigraphic horizons on the Uncompahgre Plateau uniformly increase from northwest to southeast across this area. If a significant amount of extensional post-Laramide uplift were superimposed on Laramide uplift in this specific area, departures from Williams' uniformly spaced structure contours would be noticeable. Probably these normal faults are not post-Laramide, and a major high-angle reverse fault does underlie these structures, but has not been recognized in the subsurface.

A second issue is whether the attitudes of foliation in the Proterozoic basement rocks influenced the attitudes of the highangle reverse faults along the northeastern margin of the Plateau in the map area. In the map area, the high-angle reverse 
High-angle reverse fault in the first canyon northwest of the Serpents Trail parking lot. View to the southeast shows an abrupt end of light-colored beds of the lower part of the Wingate Sandstone against the Chinle Formation at the fault. The fault dips steeply to the southwest (right). Photograph by W.C. Hood, 1998.

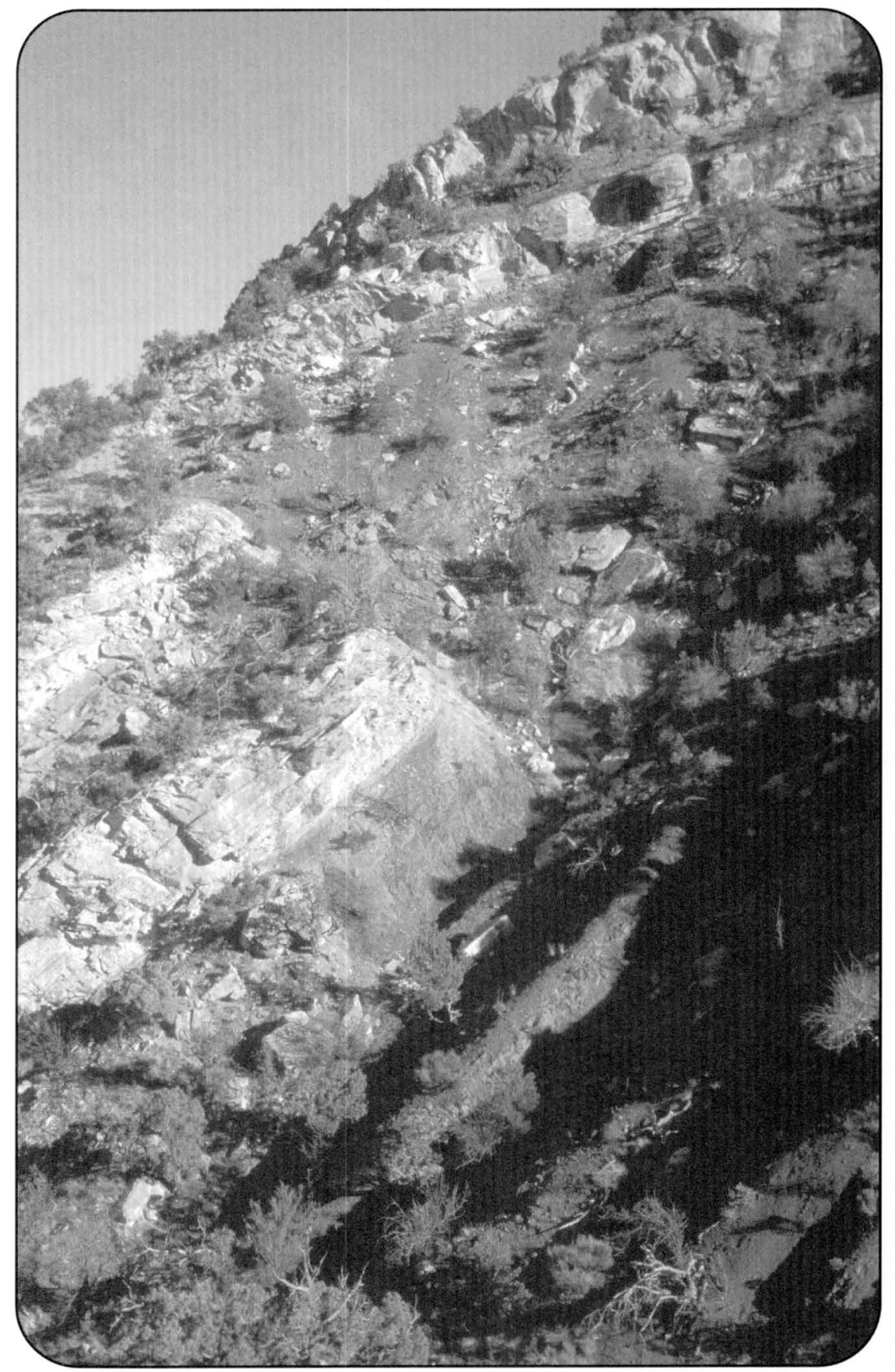

Redlands fault dips southwest to south between $62^{\circ}$ and $83^{\circ}$, averaging $72^{\circ}$. Based on numerous foliation attitudes of Proterozoic rocks, the foliation in both the meta-sedimentary rocks and the meta-igneous body is sub-parallel to the northwesttrending mountain front between No Throughfare and Ute Canyons, but the foliation in meta-sedimentary rocks is nearly perpendicular to the mountain front in the more northerly canyons. Therefore, there may be some pre-existing structural control for the southern part of the Redlands fault. In contrast, between Gold Star and Kodels Canyons where the fault progressively changes from a northwestern trend to a western trend, there is no apparent control from the metamorphic foliation attitudes.
Another subject of intense study has been the geometry of monoclines associated with the margins of the Plateau. Local areas of these folds have been the subject of numerous studies (for example, Stone, 1977; Stearns and Jamison, 1977; Jamison, 1979; Jamison and Stearns, 1982; Heyman and others, 1986; Land, 1993). In general, strata deformed over the main high-angle reverse Redlands fault form an $\mathrm{S}$-shaped fold. In greater detail, the nearly flat-lying strata on the uplifted Uncompahgre Plateau make a sharp bend or hinge line where the dip of strata and the dip of the surface of the Proterozoic rocks increase toward the northeast (sections $A-A^{\prime}$ and $\left.B-B^{\prime}\right)$. In some cases, a small-offset, down-toward-the-mountain-front, 
antithetic normal fault underlies this hinge line, at least in the northwestern part of the map area (section $A-A^{\prime}$ ). Commonly, the dip of strata in the panel of rock between the hinge line and the main high-angle reverse Redlands fault increases significantly closer to the fault. Immediately above the Redlands fault, folded strata reach the inflection point in the S-shaped fold (called an inflection hinge on section $A-A^{\prime}$ ). Locally, dips at the inflection hinge approach vertical and are locally overturned. Farther down the structure toward the northeast, the dips in the strata decrease toward the final hinge of the S-shaped fold. Northeast of that hinge, dips are nearly constant. Commonly, the Wingate Sandstone (Jwg) shows evidence of significant attenuation within the S-shaped fold where the unit thins by microfaults or shear (Jamison, 1979; Jamison and Stearns, 1982; Heyman, and others 1986; Davis, 1999). The Wingate also absorbs the fault so that the upper Wingate is only folded. As shown in section $A-A^{\prime}$, this pattern of change in attitudes of the Mesozoic strata is repeated between the main front of the Plateau and the Colorado River, suggesting that another highangle reverse fault is buried at depth. These changes in dip are also shown by traces of hinge lines on the map.

The term "draped" has been used in the past to describe the monoclinal fold above these faults. However, Erslev (1991) and Erslev and Rogers (1993) interpret similar structures elsewhere as fault propagation folds. In the hanging-wall block above the Redlands fault, microfaults have steep dips that may have resulted from anticlinal stretching or layer-parallel extension; on the footwall block, microfaults have attitudes subparallel to bedding, which may have resulted from synclinal crowding or back thrusting on bedding (Erslev, 1991).

Regardless of the shape drawn for the high-angle reverse faults at depth, problems arise when movement on faults is geometrically restored, assuming rigid-block rotation on the faults to reconstruct a pre-faulting geometry. Attempts to create $b a l$ anced sections fail because the basement-Mesozoic rock contact dips steeply to the northeast (section $A-A$ ). The problem becomes more severe if a listric-shaped fault is assumed (Kellogg and others, 1995; Erslev and others, 1999). Kellogg and others (1995), faced with a similar problem elsewhere, provided a complex deformation mechanism that geometrically solves this problem by having shear between thrust pairs rotate the block between the thrusts to the observed dip of the contact of the basement with sedimentary rocks. No evidence for such deformation exists in the map area. A simpler model may involve multiple micro-faults that formed a triangular zone that spread from the main thrust, creating a fan-like shape similar to the triangular zones of deformation described by Erslev and Selvig (1997). This model allows internal deformation of the triangular-shaped block of basement rock to change the attitude of the basement-Mesozoic contact.

\section{Late Cenozoic Regional Uplift}

As discussed in the Geologic History section above, after Laramide uplift and deformation, the entire Colorado Plateau probably endured a long period of relative quiescence in the Tertiary, during which headward erosion by low-gradient rivers progressively cut back through soft overlying strata. The Mancos Shale, in particular, was susceptible to erosion. Removal of the thick Mancos Shale from parts of the Colorado Plateau was still underway about $3.5 \mathrm{Ma}$ in middle Pliocene, as proposed by Fleming (1994), based on Pliocene deposits in southern California that contain reworked Cretaceous pollen derived from the Mancos Shale. As low-gradient precursors of the Colorado, San Juan, Green, and Dolores Rivers were eroding, they formed meanders in the soft strata. Eventually, these rivers began to entrench their meanders into the harder Mesozoic strata beneath the Mancos.

The period of regional canyon cutting probably began with late Cenozoic regional uplift across the Colorado Plateau, deeply entrenching the meanders (T.A. Steven, emeritus USGS, written commun., 2000; Steven and others, 1995; Steven and others, 1997). On the Uncompahgre Plateau, Unaweep Canyon displays evidence of the history of uplift in that region. Unaweep Canyon is an abandoned antecedent river (Figure 2) that probably was entrenched during this regional uplift. For some time the antecedent river's ability to erode kept pace with the rate of uplift.

\section{Pliocene Arching at Unaweep Canyon}

At present, two small underfit streams, East and West Creeks, drain the broad, 700-m-deep Unaweep Canyon. The meandering abandoned river course includes only part of the canyon; the river course extends $16 \mathrm{~km}$ southwest gently up gradient from Cactus Park to a drainage divide and then gently down gradient for about $35 \mathrm{~km}$ (Figure 2). From this point, roughly coincident with the Plateau's structural axis, erosion of the canyon by the youthful West Creek sharply increased the stream gradient for $18 \mathrm{~km}$ to the Dolores River at Gateway. Northeast of Cactus Park, the youthful East Creek has cut a narrow steep stream course to the Gunnison River at Whitewater. The conclusion that Unaweep Canyon was formed by a relatively large antecedent river was reached over a century ago by Peale (1877) and Gannett (1882). This concept by early geologists was followed by similar proposals by Hunt (1956b), Lohman (1961, 1965), and Cater (1966), but they disagreed on when the canyon was cut, how the canyon was cut, and whether the Colorado River or the Gunnison River cut the canyon.

Mapping in the adjacent Grand Junction quadrangle sheds light on which river may have cut Unaweep Canyon (Scott and others, in press). A string of Colorado River gravels at an elevation of about $170 \mathrm{~m}$ above the south side of the Gunnison River were found within $12 \mathrm{~km}$ of Cactus Park. Below these elevations only Gunnison River gravels were found. This indicates that the Colorado River may have originally flowed close to Unaweep Canyon and further suggests the possibility that the Colorado River may have originally flowed through Unaweep Canyon. If so, the river probably was diverted to its modern course by processes of complex stream captures by tributaries in Grand Valley. Although Gannet (1882) and Lohman (1961, 1965) came to the same conclusion for different reasons, many others (among them, Peale, 1877; Hunt, 1956; Cater, 1966) disagreed. Clearly, further detailed research is needed. 
We use the topography of modern drainage in Unaweep Canyon as evidence to propose local late Cenozoic uplift on the Uncompahgre Plateau. At Cactus Park, remnants of Gunnison River gravels rest on bedrock at an elevation of about 1,885 m, indicating that at one time the Gunnison River flowed from Cactus Park into Unaweep Canyon. This river course can be followed to the southwest from the $1,885 \mathrm{~m}$ elevation along $4 \mathrm{~km}$ of exposures of bedrock in Unaweep Canyon; however, to do so, requires climbing $55 \mathrm{~m}$ to an elevation of $1,940 \mathrm{~m}$. Because the antecedent river flowed from northeast to southwest, this $55 \mathrm{~m}$ elevation gain can only be explained by arching that occurred after the river course had been established.

Oesleby (1983) estimated from seismic refraction and vertical electric sounding data that the river course southwest of this locality had been filled with as much as $335 \mathrm{~m}$ of surficial material, and the thicknesses determined by his surveys suggested that the valleys were originally $\mathrm{V}$-shaped. About $8 \mathrm{~km}$ uphill from the junction of Cactus Park with Unaweep Canyon at a site where canyon walls are close to the valley center, the elevation of basement rock under valley fill is calculated to be at least $1,965 \mathrm{~m}$, assuming the $\mathrm{V}$-shape of the canyon below valley fill. Because Cactus Park gravels rest on bedrock at 1,885 m, then at least $80 \mathrm{~m}$ of arching must have occurred between the two points to raise the elevation of the streambed in Unaweep Canyon. This arching must have been rapid enough to defeat the river's rate of downcutting and to dam the river as indicated by remnants of lakebeds above river gravels in Cactus Park. Assuming a rate of downcutting of about $0.15 \mathrm{~m} / \mathrm{ky}$, the arch may have formed about $2.8 \mathrm{Ma}$ (late Pliocene) because Cactus Park is about $425 \mathrm{~m}$ above the present Gunnison River at Whitewater.

It has been suggested that late Pleistocene glaciation (Cole and Young, 1983) may have affected the canyon by carving triangular facets at the ends of ridges to form its U-shaped valley. However, the highest elevations on the top of the Plateau barely exceed 2,750 m, far lower than most Colorado Rocky Mountain cirques, which form at elevations greater than $3,350 \mathrm{~m}$. No obvious cirques were observed on the walls of the canyon. The U-shaped valley floor is attributed to valley fill as determined by Oesleby (1983). Because glaciers deposit debris below levels of snow accumulation, but erode only above levels of snow accumulation, it is doubtful that glaciers carved the faceted ridges at elevations below $2,135 \mathrm{~m}$. Continued meandering of the river in the valley could have faceted the ridges that display conspicuous vertical joints in the readily-weathered, coarse-grained Vernal Mesa Quartz Monzonite. In any case, possible glaciation does not bear on uplift and arching of the Plateau.

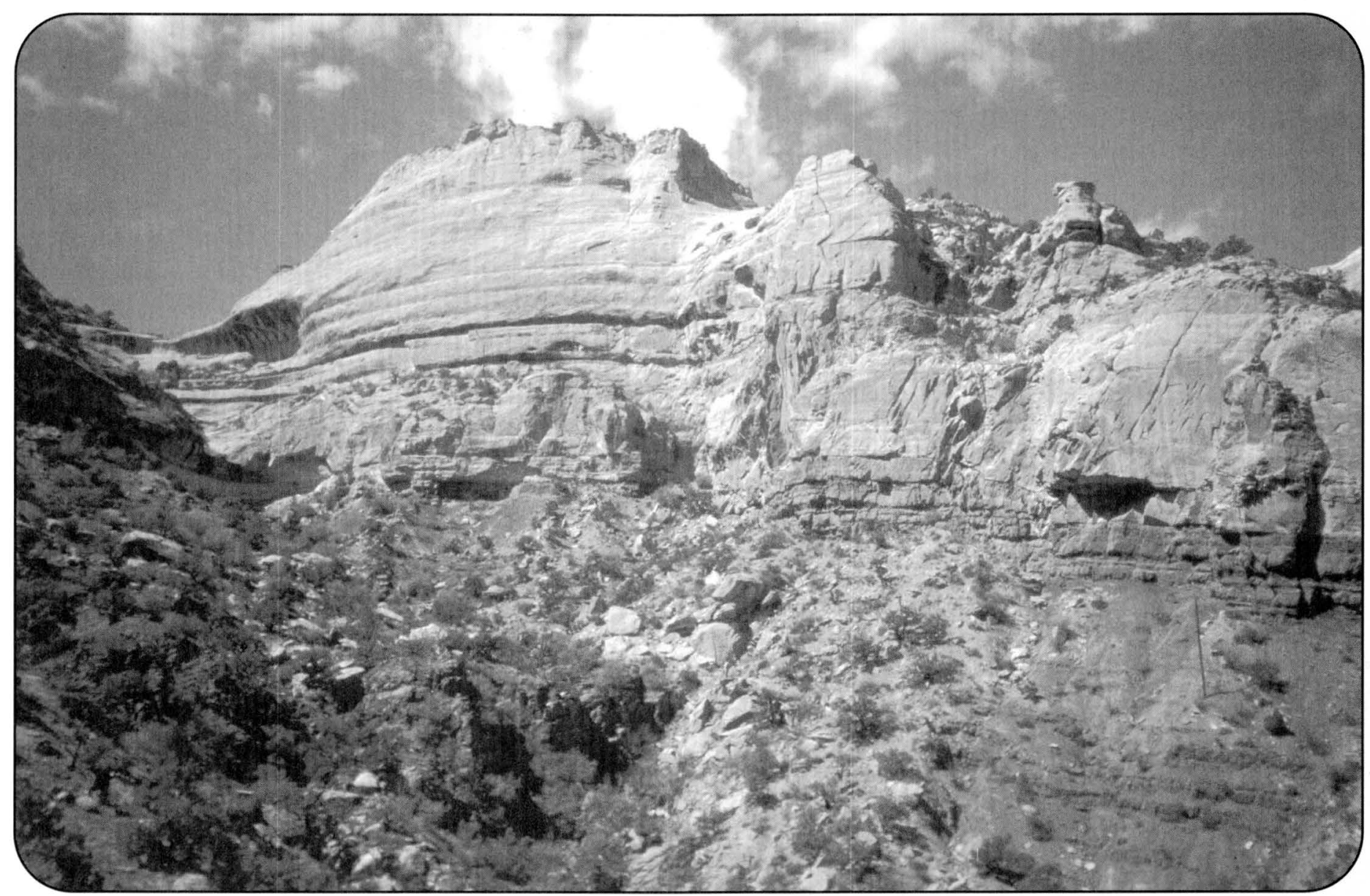

View to the southwest in the upper part of Lizard Canyon. The dark Proterozoic rocks in the left foreground abut the Chinle Formation on the right (partly covered by rock-fall deposits) where there are two normal faults. The offsets on the faults become absorbed in the two swarms of vertical fractures in the overlying Wingate Sandstone. Photograph by R.B Scott, 1998. 
Much of this proposed geomorphologic and tectonic history of Unaweep Canyon was developed during regional reconnaissance geomorphologic studies by T.A. Steven (unpublished written commun., 1999 and 2000) in conjunction with the authors of this publication. A field trip to Unaweep Canyon with T.A. Steven (emeritus, USGS) and Charles Betton (retired geologist, Grand Junction, Colo.) provided additional critical evidence.

In summary, although Pliocene(?) regional uplift and then later Pliocene local arching clearly affected the Unaweep Canyon part of the Uncompahgre Plateau, evidence of post-Laramide uplift has not been recognized in the Colorado National Monument map area. But the absence of evidence does not exclude the possibility of minor, local, post-Laramide uplift in the map area. This conclusion for Colorado National Monument and the surrounding Uncompahgre Plateau is consistent with evidence of differential amounts of local Late Cenozoic uplift superimposed on a background of general regional uplift found elsewhere in the Rocky Mountains of Colorado (Steven and others, 1997; Erslev and others, 1999; Scott, Lidke, and others, 1999).

\section{Geologic Hazards}

The Brushy Basin Member of the Morrison Formation contains abundant, expansive smectitic clays. When wet, these expansive clays reduce the shear strength of the Brushy Basin Member (Jmb) so that landslides commonly displace the Brushy Basin Member and the overlying Burro Canyon $(\mathrm{Kb})$ and Dakota (Kd) Formations. Some of these landslides probably formed under conditions wetter than those of the present.

Old landslide deposits (Q1so) partly veneer all sides of Black Ridge and have flowed across lower stratigraphic units onto the floor of Monument Canyon. They also locally cover the dipslope of the Morrison-Burro Canyon-Dakota Formations about 1 to $1.5 \mathrm{~km}$ south of the northern border and 4 to 5 $\mathrm{km}$ east of the west border of the map area. Although many or most of these landslides probably were generated during previous wetter climatic episodes and seem relatively stable now, bulges in roadcuts along Rim Rock Drive in the Monument suggest that these slides may have been reactivated after road construction. Excavations, excessive irrigation, and other disturbances related to home construction or excessive lawn watering on either old landslides or on gentle dipslopes underlain by this sequence of strata may cause either renewed or new sliding in the Redlands area.

Small, young landslide deposits (Q1sy) form along the south bank of the Colorado River. Roads and structures are subject to landslide hazards, especially those that are close to river bluffs where excess irrigation or lawn water has been applied. The most recent landslide began during the winter of 2000 and is still active during writing; the landslide has destroyed a house above the south bank of the Colorado River $0.2 \mathrm{~km}$ west of the east border of the map area. In the adjacent Grand Junction 7.5-minute quadrangle, young landslides have damaged a sewage treatment plant and an irrigation pump station.

Watering of lawns in the Redlands area has been sufficient to locally activate movement of expansive soils and clays on and in the Brushy Basin Member of the Morrison (Jmb) as well as in some of the overlying map units. Damage to homes and roads is evident, particularly in the adjacent Grand Junction 7.5-minute quadrangle. Smectitic clays are alteration products of volcanic ash; therefore, these clays retain the higher radioactivity of the volcanic ash. Cole and others (1999) used a portable gamma-ray spectrometer to detect higher concentrations of gamma-ray producing radioactive elements in those parts of the strata that have the highest concentrations of expansive clays and, therefore, are those most prone to landsliding.

Surficial deposits that contain debris from the Brushy Basin Member are particularly susceptible to shrinking, swelling, and hydrocompaction; all of these deposits make an unstable base for roads or foundations of buildings. Eolian sand (Qe) is probably susceptible to hydrocompaction and possibly to piping. Cienaga deposits (Qcg) are poorly suited for supporting roads and structures or for the efficient operation of septic systems. Hazards commonly associated with these deposits include seasonal high water tables, low bearing capacity, and the presence of sulfate minerals, which deteriorate untreated concrete and steel. The Brushy Basin Member of the Morrison (Jmb), which underlies Cienaga deposits, is relatively impermeable and contains abundant expansive clay.

Intense summer thunderstorms are common on the Uncompahgre Plateau in the map area and supply large volumes of water in a short time to the canyons of Colorado National Monument, where constrictions in the canyons increase both the rate of flow and the flood heights. The resulting flash floods present a serious geologic hazard not only to visitors on foot in narrow canyons, but also to houses and roads that are close to flood-prone intermittent streams where these streams exit through narrow canyons onto the Redlands area. Boulders more than $2 \mathrm{~m}$ in diameter have been moved during historic and prehistoric flash floods. Alluvium (Qal) and flood-plain and stream-channel deposits (Qfp) are subject to periodic flooding. The Colorado River floods each spring following the period of maximum melting of thick snow packs in mountainous upstream areas.

Unstable cliffs formed by the Wingate Sandstone (Jwg), the Kayenta Formation (Jk), and the Salt Wash Member of the Morrison (Jms) produce rockfalls that pose a local geologic hazard. Where road construction has destabilized the rock, large rockfalls have occurred, damaging Rim Rock Drive in the Monument. Such a rockfall occurred in January 2000 when automobile-size blocks of sandstone from the Salt Wash Member of the Morrison Formation (Jms) slid on thin clay layers and toppled onto Rim Rock Drive, blocking traffic for at least a month. 


\section{Geologic Resources}

The most important geologic resource in the map area is the beauty of the erosional features and rocks exposed in the margin of the Uncompahgre Plateau. Many visitors to Colorado National Monument and the surrounding U.S. Bureau of Land Management lands support the tourist industry of Grand Junction and Grand Valley.

The map area contains abundant sand and gravel resources. Gravel pits are shown on the map by dotted boundaries in map unit Qfp. Most of these deposits contain rounded to wellrounded and well-sorted pebble-cobble gravel. The clasts consist largely of basaltic rocks, quartzite, micaceous red sandstone, gray fine- to medium-grained granitic rocks, "oil shale" of the Green River Formation, and intermediate volcanic rocks. The matrix of the gravel generally consists of silty sand and sand. The gravels are commonly overlain by 1 to $2 \mathrm{~m}$ of overbank and possibly eolian materials containing silty fine sand and fine sand. The gravels also contain about 5 to 15 percent "oil shale" clasts, derived from the Green River Formation. The "oil shale" has a low bearing capacity. Although, these gravels may be suitable for road base, they may not be suitable as an aggregate for concrete and asphalt. Drill-hole data for the area north of the Colorado River indicate that 3 to $15 \mathrm{~m}$ of sheetwash deposits (Qsw) overlie 3 to $7 \mathrm{~m}$ of Colorado River gravel in unit Qfp (Ken Weston; U.S. Bureau of Reclamation, written commun., 1999; Phillips, 1986). These data, however, may not represent the entire thickness of unit Qfp, because it is difficult to distinguish in drilling records between sheetwash deposits (Qsw) and lenses of sandy silt in the upper part of unit Qfp. The thickness of unit Qfp locally may exceed $7 \mathrm{~m}$.

\section{Acknowledgments}

The hospitality and cooperation of the staff of Colorado National Monument added significantly to the pleasure of mapping the Monument and surrounding area, especially by providing housing with showers, kitchen, and a terrific view. In particular, the friendly support of the previous Superintendent, Steve Hickman, and his staff of park rangers made normally difficult tasks much easier. Pat Perrotti, previous Resource Manager for the Monument, went out of his way to fill us in on current geologic events at the Monument. Bill Rodgers, Protection Ranger, spent a day in the field with us to locate critical boundaries in the new southern addition to the Monument. Judi Lofland, Museum Technician at the Monument, provided old photographs of the area and helped us with important historical details. Both Superintendent Palma Wilson and Dave Price, Resource Manager for the Monument, contributed editorial details. Bruce Heise of the National Park Service Geologic Resources Division and liaison to the USGS helped make the map a high-priority product. Joe Gregson, also with the Geologic Resources Division, obtained and transferred digital line graph (DLG) data critical for a legible topographic base for the map. The partnership with both the
Colorado National Monument Association and the National Park Service has been instrumental in the creation of this product for the public. In the USGS, Paco Van Sistine of the Earth Surface Processes Team provided prompt and critical GIS help, as did Nancy Shock and Alex Donatich of the Central Publication Group. The constructive reviews by Bruce Bryant and Jim Yount of the USGS significantly improved the quality of the map and text. Discussions with Robert Young of Grand Junction were valuable and invigorating. The radiometric dating by Mick Kunk and Dan Unruh of the USGS provided critical constraints on the ages of Proterozoic events. The ${ }^{14} \mathrm{C}$ dates supplied by Jack McGeehin of the USGS not only gave us the timing for geologic events during the late Quaternary, but also allowed us to date the minimum period of Native American habitation in the canyons of Colorado National Monument. Working with Tom Steven on the geomorphologic implications of Unaweep Canyon has been both a most enlightening and invigorating experience. Finally, the impressive digital creative art of Carol Quesenberry and the immensely thorough editorial guidance of Craig Brunstein spurred us on to the finish. It certainly takes teamwork to make a map.

\section{References Cited}

Allen, J.R.L., 1970, Physical processes of sedimentation: London, George Allen and Unwin, $248 \mathrm{p}$.

American Geological Institute, 1982, Grain-size scales used by American geologists, modified Wentworth scale, in Data Sheets (2nd ed.): Falls Church, Va., American Geological Institute, Sheet 17.1.

Anderson, 0.J., and Lucas, S.G., 1998, Redefinition of Morrison Formation (Upper Jurassic) and related San Rafael Group strata, southwestern U.S.: Modern Geology, v. 22, p. 39-69.

Aubrey, W.M., 1998, A newly discovered, widespread fluvial facies and unconformity marking the upper Jurassic/Lower Cretaceous boundary, Colorado Plateau: Modern Geology, v. 22, p. 209-233.

Birkeland, P.W., 1999, Soils and Geomorphology: New York, Oxford University Press, $430 \mathrm{p}$.

Boggs, S., Jr., 1995, Principles of sedimentology and stratigraphy: Englewood Cliffs, Prentice Hall, edition 2, $774 \mathrm{p}$.

Campbell, C.V., 1967, Lamina, laminaset, bed and bedset: Sedimentology, v. 8, p. 7-26.

Cashion, W.B., 1973, Geologic and structure map of the Grand Junction quadrangle, Colorado and Utah: U.S. Geological Survey Miscellaneous Investigations Series Map I-736, scale 1:250,000.

Case, J.E., 1966, Geophysical anomalies over Precambrian rocks, northwestern Uncompahgre Plateau, Utah and Colorado: American Association of Petroleum Geologists Bulletin, v. 50, p. 1423-1443.

Cater, F.W., 1966, Age of the Uncompahgre uplift and Unaweep Canyon, west-central Colorado: U.S. Geological Survey Professional Paper 550-C, p. C86-C92.

Cobban, W.A., Merewether, E.A., Fouch, T.D., and Obradovich, J.D., 1994, Some Cretaceous shorelines in the western interior of the United States, in Caputo, M.V., Peterson, J.A., and Franczyk, K.J., eds., Mesozoic Systems of the Rocky Mountain Region, USA: Rocky Mountain Section of the Society of Economic Paleontologists and Mineralogists (Society for Sedimentary Geology), p. 393-414. 
Cole, R.D., 1987, Cretaceous rocks of the Dinosaur Triangle, in Averett, W.R., ed., Paleontology and Geology of the Dinosaur Triangle: Grand Junction Geological Society 1987 Guidebook, p. 21-35.

Cole, R.D., Hood, W.C., and Scott, R.B., 1999, Sedimentological reevaluation, high-resolution gamma-ray log, and landslide hazards of the stratigraphic section at Colorado National Monument, Western Colorado: Geological Society of America Abstracts with Programs, v. 31 , no. 7, p. A-283.

Cole, R.D., and Moore, G.E., 1994, Sequence stratigraphy of Cedar Mountain-Dakota interval, western and southern Piceance Creek basin, Colorado: American Association of Petroleum Geologists Annual Convention Program, v. 3, p. 124.

Cole, R.D., and Young, R.G., 1983, Evidence for glaciation in Unaweep Canyon, Mesa County, Colorado: Grand Junction Geological Society, 1983 Field Trip, p. 73-80.

Craig, L.C., 1981, Lower Cretaceous rocks southwestern Colorado and southeastern Utah, in Geology of the Paradox Basin: Rocky Mountain Association of Geologists, p. 195-200.

Davis, G.H., 1999, Structural geology of the Colorado Plateau region of southern Utah, with special emphasis on deformation bands: Geological Society of America Special Paper 342, 157 p.

Dubiel, R.S., 1992, Sedimentology and depositional history of the Upper Triassic Chinle Formation in the Uinta, Piceance, and Eagle basins, northwestern Colorado and Northeastern Utah, in Evolution of sedimentary basins-Uinta and Piceance basins: U.S. Geological Survey Bulletin 1787-W, p W1-W25.

Dubiel, R.S., 1994, Triassic deposystems, paleogeography, and paleoclimate of the western interior, in Caputo, M.V., Peterson, J.A., and Franczyk, K.J., eds., Mesozoic Systems of the Rocky Mountain Region, USA: Rocky Mountain Section of Society of Economic Paleontologists and Mineralogists (Society for Sedimentary Geology), p. 133-168.

Dunham, R.J., 1962, Classification of carbonate rocks according to depositional textures, in Ham, W.E., ed., Classification of Carbonate Rocks: American Association of Petroleum Geologists Memoir 1, p. 108-121.

Ekdale, A.A., Bromley, R.G., and Pemberton, S.G., eds., 1984, Ichnology: the use of trace fossils in sedimentology and stratigraphy: Society of Economic Paleontologists and Mineralogists, Short Course Notes $15,317 \mathrm{p}$

Erslev, E.A., 1991, Trishear fault-propagation folding: Geology, v. 19, p. $617-620$.

1993, Thrusts, backthrusts, and detachment of Rocky Mountain foreland arches, in Schmidt, C.J., Chase, R.B., and Erslev, D.A., eds., Laramide Basement Deformation in the Rocky Mountain Foreland of the Western United States: Boulder, Colorado, Geological Society of America Special Paper 280, p. 339-358.

Erslev, E.A., Kellogg, K.S., Bryant, B., Ehrlich, T.K., Holdaway, S.M., and Naeser, C.W., 1999, Laramide to Holocene structural developments of the northern Colorado Front Range, in Lageson, D.R., Lester, A.P., and Trudgill, B.D., eds., Colorado and Adjacent Areas: Boulder, Colo., Geological Society of America Field Guide 1, p. 21-40.

Erslev, E.A., and Rogers, J.L., 1993, Basement-cover geometry of Laramide fault-propagation folds, in Schmidt, C.J., Chase, R.B., and Erslev, D.A., eds., Laramide Basement Deformation in the Rocky Mountain Foreland of the Western United States: Boulder, Colorado, Geological Society of America Special Paper 280, p. 125-146.
Erslev, E.A., and Selvig, Bjorn, 1997, Thrusts, backthrusts and triangular zones: Laramide deformation in the northeastern margin of the Colorado Front Range, in Bolyard, D.W., and Sonnenberg, S.A., eds., Geologic History of the Colorado Front Range: Denver, Colorado, Rocky Mountain Association of Geologists, p. 65-76.

Fleming, R.F., 1994, Cretaceous pollen in Pliocene rocks: Implications for Pliocene climate in the southwestern United States: Geology, v. 22, p. 787-790.

Folk, R.L., 1974, Petrology of sedimentary rocks: Austin, Texas, Hemphill Publishing Co., 182 p.

Fryberger, S.G., Krystinik, L.F., and Schenk, C.J., 1990, Tidally flooded back-barrier dunefield, Guerrero Negro area, Baja California, Mexico: Sedimentology, v. 37, p. 23-44.

Fouch, T.D., Lawton, T.F., Nichols, D.J., Cashion, W.B., and Cobban, W.A., 1983, Patterns and timing of synorogenic sedimentation in Upper Cretaceous rocks of central and northeast Utah, in Reynolds, M.W., and Dolly, E.D., eds., Mesozoic Paleogeography of the West-Central United States: Denver, Rocky Mountain Section of the Society of Economic Paleontologists and Mineralogists Rocky Mountain Paleogeography Symposium 2, p. 305-336.

Gannett, Henry, 1882, The Unaweep Canyon [Colorado]: Popular Scientific Monthly, v. 20, 781-786.

Geological Society of America, 1999, Geological time scale: Boulder, Geological Society of America.

Gile, L.H., Peterson, F.F., and Grossman, R.B., 1966, Morphological and genetic sequences of carbonate accumulation in desert soils: Soil Science, v. 101, p. 347-360.

Guthrie, R.L., and Witty, J.E., 1982, New designations for soil horizons and layers and the new Soil Survey Manual: Soil Science Society of America Journal, v. 46, p. 443-444.

Hansen, W.R., ed., 1991, Suggestions to Authors of the Reports of the United States Geological Survey, Seventh Edition: Washington, D.C., U.S. Government Printing Office, 289 p.

Hansen, W.R., and Peterman, Z.E., 1968, Basement-rock geochronology of the Black Canyon of the Gunnison, Colorado: U.S. Geological Survey Professional Paper 600-C, p. C80-C90.

Hedge, C.E., Peterman, Z.E., Case, J.E., and Obradovich, J.D., 1968, Precambrian geochronology of the northwestern Uncompahgre Plateau, Utah and Colorado: U.S. Geological Survey Professional Paper 600-C, p. C91-C96.

Heyman, 0.G., 1983, Distribution and structural geometry of faults and folds along the northwestern Uncompahgre uplift, western Colorado and eastern Utah: Grand Junction, Colorado, Grand Junction Geological Society 1983 field trip, p. 45-57.

Heyman, 0.G., Huntoon, P., and White-Heyman, M., 1986, Laramide deformation of the Uncompahgre Plateau-Geometry and Mechanisms, in Stone, D.S., ed., New Interpretations of Northwest Colorado Geology: Rocky Mountain Association of Geologists Guidebook, p. 65-76.

Hunt, C.B., 1956a, Cenozoic Geology of the Colorado Plateau: U.S. Geological Survey Professional Paper 279, 99 p.

1956b, Geology of the Taylor site, Unaweep Canyon, Colorado, in Archeological investigations on the Uncompahgre Plateau in west central Colorado: Denver Museum of Natural History Proceedings, no. 2, p. 64-69.

Ingram, R.L., 1954, Terminology for the thickness of stratification and parting units in sedimentary rocks: Geological Society of America Bulletin, v. 65, p. 937-938. 
Izett, G.A., and Wilcox, R.E., 1982, Map showing localities and inferred distributions of the Huckleberry Ridge, Mesa Falls, and Lava Creek ash beds (Pearlette family ash beds) of Pliocene and Pleistocene age in the Western United States and Southern Canada: U.S. Geological Survey Miscellaneous Investigations Series Map 1-1325, scale $1: 4,000,000$.

Jamison, W.R., 1979, Laramide deformation of the Wingate Sandstone, Colorado National Monument: A study of cataclastic flow: College Station, Texas, unpublished dissertation, Texas A\&M University, $170 \mathrm{p}$.

Jamison, W.R., and Stearns, 1982, Tectonic deformation of Wingate Sandstone, Colorado National Monument: American Association of Petroleum Geologists Bulletin, v. 66, p. 2584-2608.

Kellogg, K.S., Schmidt, C.J., and Young, S.W., 1995, Basement and coverrock deformation during Laramide contraction in the northern Madison Range (Montana) and its influence on Cenozoic Basin Formation: American Association of Petroleum Geologists Bulletin, v. 79, no. 8, p. 1117-1137.

Kocurek, Gary, and Dott, R.H., Jr. 1983, Jurassic paleogeography and paleoclimate of the central and southern Rocky Mountains region, in Reynolds, M.W., and Dolly, E.D., eds., Mesozoic Paleogeography of the West-Central United States, Rocky Mountain Paleogeography, Symposium 2: Denver, Colo., Rocky Mountain Section, Society of Economic Paleontologists and Mineralogists, 101-116.

Kowallis, B.J., Christiansen, E.H., and Deino, A.L., 1991, Age of the Brushy Basin Member of the Morrison Formation, Colorado Plateau, western USA: Cretaceous Research, v. 12, p. 483-493.

Kowallis, B.J., Christiansen, E.H., and Deino, A.L., Peterson, Fred, Turner, C.E., Kunk, M.J., and Obradovich, J.D., 1998, The age of the Morrison Formation: Modern Geology, v. 22, p. 235-260.

Land, Lewis, 1993, Three-dimensional characterization of basement faults and forced folds in clastic rocks along the northeastern edge of the Uncompahgre Plateau, western Colorado: Norman, Oklahoma, unpublished thesis, University of Oklahoma, $129 \mathrm{p}$.

Lohman, S.W., 1961, Abandonment of Unaweep Canyon, Mesa County, Colorado, by capture of the Colorado and Gunnison Rivers: Article 60 in U.S. Geological Survey Professional Paper 424-B, p. B144-B146.

1963, Geologic map of the Grand Junction area, Colorado: U.S. Geological Survey Miscellaneous Investigations Series Map I-404, scale 1:31,680.

-1965, Geology and Artesian Water Supply, Grand Junction Area, Colorado: U.S. Geological Survey Professional Paper 451, 149 p.

1981, The geologic story of Colorado National Monument: U.S. Geological Survey Bulletin 1508, 142 p.

Marvin, R.F., Mehnert, H.H., and Montjoy, W.M., 1966, Age of the basalt cap on Grand Mesa, in Geological Survey Research 1966: U.S. Geological Survey Professional Paper 550-A, p. A81.

McKee, E.D., and Weir, G.W., 1953, Terminology for stratification and cross-stratification in sedimentary rocks: Geological Society of America Bulletin, v. 64, p. 381-390.

Miller, D.M., Nilsen, T.H., and Bilodeau, W.L., 1992, Late Cretaceous to early Eocene geologic evolution of the U.S. Cordillera, in Burchfiel, B.C., Lipman, P.W., and Zoback, M.L., eds., The Cordilleran Orogen: Coterminous U.S.: Boulder, Colorado, Geological Society of America, The Geology of North America, v. G-3, p 205-260.

Munsell Color, 1973, Munsell soil color charts: Baltimore, Md., Kollmorgen Corp., Macbeth Division.
Oesleby, T.W., 1983, Geophysical measurement of valley fill thickness, Unaweep Canyon, West Central Colorado: Grand Junction Geological Society, 1983 Field Trip, p. 71-72.

0'Sullivan, R.B., 1980, Stratigraphic sections of Middle Jurassic San Rafael Group and related rocks from the Green River to the Moab area in east-central Utah: U.S. Geological Survey Miscellaneous Field Studies Map MF-1247.

O'Sullivan, R.B., 1992, The Jurassic Wanakah and Morrison Formations in the Telluride-Ouray-Western Black Canyon Area of southern Colorado: U.S. Geological Survey Bulletin 1927, 24 p.

O'Sullivan, R.B., and Pipiringos, G.N., 1983, Stratigraphic sections of Middle Triassic Entrada Sandstone and related rocks from Dewey Bridge, Utah, to Bridgeport, Colorado: U.S. Geological Survey Oil and Gas Investigations Chart OC-122.

Padian, K., 1989, Presence of dinosaur Scelidosaurus indicates Jurassic age for the Kayenta Formation (Glen Canyon Group, northern Arizona): Geology, v. 17, p. 438-441.

Peale, A.C., 1877, Report on the Grand River district, Colorado: U.S. Geological and Geographical Survey of the Territories, $9^{\text {th }}$ Annual Report, p. 31-101.

Pemberton, S.G., MacEachern, J.A., and Frey, R.W., 1992, Trace fossil facies models: environmental and allostratigraphic significance, in Walker, R.G., and James, N.P., eds., Facies Models, Response to Sea Level Change: Geological Association of Canada, p. 47-72.

Peterson, Fred, 1994, Sand dunes, sabkhas, streams, and shallow seas: Jurassic paleogeography in the southern part of the Western Interior, basin, in Caputo, M.V., Peterson, J.A., and Franczyk, K.J., eds., Mesozoic Systems of the Rocky Mountain Region, USA: Rocky Mountain Section of Society of Economic Paleontologists and Mineralogists (Society for Sedimentary Geologyl, p. 233-272.

Peterson, Fred, 1988a, Stratigraphy and nomenclature of Middle and Upper Jurassic rocks, western Colorado Plateau, Utah and Arizona, in Revisions to stratigraphic nomenclature of Jurassic and Cretaceous rocks of the Colorado Plateau: U.S. Geological Survey Bulletin 1633-B, p. 17-56.

Peterson, Fred, 1988b, Pennsylvanian to Jurassic eolian transport systems in the western United States: Sedimentary Geology, v. 56, p. 207-260.

Peterson, Fred, and Pipiringos, G.N., 1979, Stratigraphic relationships of the Navajo Sandstone to Middle Jurassic formations in parts of southern Utah and northern Arizona: U.S. Geological Survey Professional Paper 1035-B, p. B1-B43.

Peterson, Fred, and Turner, C.E., 1998, Stratigraphy of the Ralston Creek and Morrison Formations (Upper Jurassic) near Denver, Colorado: Modern Geology, v. 22, p. 3-38.

Pettijohn, F.J., Potter, P.E., and Siever, R., 1973, Sand and Sandstone: New York, Springer-Verlag, $553 \mathrm{p}$.

Phillips, W.A., 1986, Cobble aquifer investigation: Colorado River Basin Salinity Control Project: Grand Junction, Colorado, Grand Junction Office, U.S. Bureau of Reclamation, $20 \mathrm{p}$.

Picard, M.D., 1971, Classification of fine-grained sedimentary rocks: Journal of Sedimentary Petrology, v. 41, p. 179-195.

Piety, L.A., 1981, Relative dating of terrace deposits and tills in the Roaring Fork Valley, Colorado: Boulder, University of Colorado, M.S. thesis, $209 \mathrm{p}$.

Pipiringos, G.N., and O'Sullivan, R.B., 1978, Principal unconformities in Triassic and Jurassic rocks, Western Interior United States-A preliminary survey: U.S. Geological Survey Professional Paper 1035-A, 29 p. 
Potter, P.E., Maynard, J.B., and Pryor, W.A., 1980, Sedimentology of shale: New York, New York Springer-Verlag, 306 p.

Powers, M.C., 1953, A new roundness scale for sedimentary particles: Journal of Sedimentary Petrology, v. 23, p. 117-119.

Reed, J.C., Jr., Bickford, M.E., Premo, W.R., Aleinikoff, J.N., and Pallister, J.S., 1987, Evolution of the Early Proterozoic Colorado province: Constraints from U-Pb geochronology: Geology, v. 15, p. 861-865.

Richmond, G.M., and Fullerton, D.S., 1986, Introduction to Quaternary glaciations in the United States of America, in Sibrava, V., Bowen, D.0., and Richmond, G.M., eds., Quaternary Glaciations in the Northern Hemisphere: Quaternary Science Reviews, v. 5, p. 3-10.

Rock-Color Chart Committee, 1951, Rock-Color Chart: Boulder, Colo., Geological Society of America.

Scott, R. B., Carrara, P.E., Hood, W.C., and Murray, K.E., [in press], Geologic Map of the Grand Junction quadrangle, Mesa County, Colorado: U.S. Geological Survey Miscellaneous Field Studies Map, scale $1: 24,000$.

Scott, R.B., Hood, W.C., Johnson, James, Tausch, Robin, Sexton, T.O., Perrotti, Patrick, 1999, Charcoal record in sediments and fire ecology history of piñon-juniper uplands of the Uncompahgre uplift, western Colorado: Geological Society of America Abstracts with Programs, v. 31, no. 7, p. A-482-483.

Scott, R.B., Lidke, D.J., Hudson, M.R., Perry, W.J., Jr., Bryant, Bruce, Kunk, M.J., Budahn, J.R., and Byers, F.M., Jr., 1999, Active evaporite tectonics in the Eagle River valley and the southwestern flank of the White River uplift, Colorado, in Lageson, D.R., Lester, A.P., and Trudgill, B.D., eds., Colorado and Adjacent Areas: Boulder, Colorado, Geological Society of America Field Guide 1, p. 97-114.

Scott, R.B., and Shroba, R.R., 1997, Revised preliminary geologic map of the New Castle quadrangle, Garfield County, Colorado: U.S. Geological Survey Open-File Report 97-737, scale 1:24,000.

Shroba, R.R., 1994, Quaternary loess stratigraphy along the Colorado River between Glenwood Springs and Rifle, Colorado-Preliminary findings: American Quaternary Association, $13^{\text {th }}$ Biennial Meeting, Minneapolis, Minn., Abstracts, p. 24.

Shroba, R.R., and Scott, R.B., 1997, Revised preliminary geologic map of the Rifle quadrangle, Garfield County, Colorado: U.S. Geological Survey Open-File Report 97-852, scale 1:24,000.

Soil Survey Staff, 1975, Soil taxonomy: U.S. Department of Agriculture Handbook 436, $754 \mathrm{p}$.

Stearns, D.W., and Jamison, W.R., 1977, Deformation of sandstones over basement uplifts, Colorado National Monument, in Veal, H.D., ed., Exploration Frontiers of the Central and Southern Rockies: Denver, Colorado, Rocky Mountain Association of Geologists, 1977 Symposium, p. 31-39.

Steven, T.A., Hon, K., and Lanphere, M.A., 1995, Neogene geomorphic evolution of the central San Juan Mountains near Creede, Colorado: U.S. Geological Survey Miscellaneous Investigations Series Map I2504.

Steven, T.A., Evanoff, Emmett, and Yuhas, R.H., 1997, Middle and late Cenozoic tectonic and geomorphic development of the Front Range of Colorado, in Bolyard, D.W., and Sonnenberg, S.A., eds., Geologic History of the Colorado Front Range: Denver, Colo., Rocky Mountain Association of Geologists, 1997 RMS-AAPG Field Trip \#7, p. 115-124.

Streckeisen, A.L., 1973, Plutonic rocks, classification and nomenclature recommended by the IUGS subcommittee on the systematics of igneous rocks: Geotimes, v. 18, no. 10, p. 25-29.
Stone, D.S., 1977, Tectonic history of the Uncompahgre uplift, in Exploration Frontiers of the Central and Southern Rockies-1977 Symposium: Rocky Mountain Association of Geologists, p. 23-30.

Stuiver, Minze, Reimer, P.J., Bard, Edouard, Beck, J.W., Burr, G.S., Hughen, K.A., Kromer, Bernd, McCormac, Gerry, van der Plicht, Johannes, and Spurk, Marco, 1998, Intcal98 radiocarbon age calibration, 24,000-0 cal BP: Radiocarbon, v. 40, no. 3, p 1041-1083.

Turner, C.E., and Fishman, N.S., 1991, Jurassic Lake T'oo'dichi'. A large alkaline, saline lake, Morrison Formation, eastern Colorado Plateau: Geological Society of America Bulletin, v. 103, p. 538-558.

Varnes, D.J., 1978, Slope movement types and process, in Schuster, R.L., and Krizek, R.J., eds., Landslides, analysis, and control: National Academy of Sciences, Transportation Research Board Special Report 176, p. 11-33.

Wentworth, C.K., 1922, A scale of grade and class terms for clastic sediments: Journal of Geology, v. 30, p. 377-392.

White, M.A., and Jacobson, M.I., 1983, Structures associated with the southwest margin of the Ancestral Uncompahgre uplift: Grand Junction, Colo., Grand Junction Geological Society 1983 field trip, p. 3339.

Whitney, J.W., Piety, L.A., and Cressman, S.L., 1983, Alluvial history in the White River basin, northwest Colorado: Geological Society of America Abstracts with Programs, v. 15, no. 5, p. 328.

Williams, P.L., 1964, Geology, structure, and uranium deposits of the Moab quadrangle, Colorado and Utah: U.S. Geological Survey Miscellaneous Investigations Series Map I-360, scale 1:100,000.

Willis, G.C., 1994, Geologic map of the Harley dome quadrangle, Grand County, Utah: Utah Geological Survey Map M-157, scale 1:24,000.

Ye, Hongzhuan, Royden, Leigh, Burchfiel, Clark, and Schuepbach, Martin, 1996, Late Paleozoic deformation of interior North America: The greater ancestral Rocky Mountains: American Association of Petroleum Geologists Bulletin, v. 80, p. 1397-1432.

Young, R.G., 1959, Cretaceous deposits of the Grand Junction area, Garfield, Mesa, and Delta Counties, Coloarado: Rocky Mountain Association of Geologists, $11^{\text {th }}$ field conference, p. 17-25.

\section{Glossary}

This glossary contains geological words and combinations of words not found in common dictionaries, for example, Webster's New World Dictionary, Third College Edition, 1988, Simon \& Schuster, Inc. Words that are italicized in the text are included in this glossary. Most of the definitions were simplified and modified from the Glossary of Geology, Fourth Edition, published by the American Geological Institute, 1997; used with their permission.

anhedral Form of a crystal that does not display its crystal faces. antecedent river A river that maintains its course as the underlying rocks are deformed; in this case, cutting a canyon as the Uncompahgre Plateau is uplifted and arched.

antithetic fault A fault that is secondary to a major fault, formed at the same time as the major fault, but is oriented at a high angle to the major fault, and has a sense of offset opposite that of the major fault.

${ }^{40} \mathrm{Ar} /{ }^{39} \mathrm{Ar}$ method A radiometric dating technique based on the rate of decay of radioactive isotopes of potassium and argon daughter products. 
Archean The oldest Eon recorded in rocks on Earth, between 2,500 and 3,800(?) Ma.

asymmetric ripple lamination, ripple stratification, or ripple marks Ripple lamination, ripple stratification, or ripple marks that are not symmetrical; implies current transport.

attenuation A process of thinning; in this case, thinning of strata caused by folding.

attitude The structural position of rock layers or structures in space; determined by measurement of strike and dip of planar features such as bedding or faults.

balanced cross sections Cross sections that restore strata to their original geometry after offsets on faults and folds are removed.

batholith An igneous intrusion displaying greater than $100 \mathrm{~km}^{2}$ of exposure. (See stock for contrast).

bearing capacity The maximum weight that ground can support without failing by shear.

bioturbated Description of bedding that has been disturbed by biological activity such as burrowing.

boudin A sausage-shaped pod of metamorphic rock encased in surrounding metamorphic rock matrix.

bounding surface An erosional surface that truncates and separates groups of cross-beds.

braided streams or braided-river systems Streams or rivers with anastomosing, or braided, patterns of water courses.

${ }^{14} \mathrm{C}$ dating $\mathrm{A}$ radiometric dating technique based on the rate of radioactive decay of ${ }^{14} \mathrm{C}$, an isotope of carbon.

calc-alkalic A chemical group of igneous rocks in which the $\mathrm{SiO}_{2}$ weight percent is between 56 and 61 and the $\mathrm{CaO}$ and $\mathrm{Na}_{2} \mathrm{O}+\mathrm{K}_{2} \mathrm{O}$ weight percents are equal to each other. Commonly rocks of this chemistry are indicative of continental margin magmatism.

calc-silicate A metamorphic rock that contains $\mathrm{Ca}$-rich silicate minerals, such as epidote, diopside, tremolite, actinolite, and grossularite (Ca garnet), and that was probably originally $\mathrm{Ca}$ rich sediments.

cataclastic flow Deformation of rock caused by intergranular movement of particles relative to one another.

charophyte A fresh-water green algae.

cienaga-type deposits Deposits formed in marshy areas in arid climates.

clast Rock fragment greater than $2 \mathrm{~mm}$ in diameter.

clast supported A sediment or soil in which there are sufficient clasts so that clasts rest on one another and therefore support the weight of overlying material.

climbing dunes Dunes banked against the windward side of a topographic rise.

colluvial deposits Any deposits consisting of loose, heterogeneous, and incoherent masses of rock fragments and (or) finer sediment that were emplaced by mass wasting at or near the base of slopes.

comagmatic Igneous rocks that were derived from a common parent magma. combined flow ripple marks, combined ripple marks, or crossripple marks Combination of current and wave action; for example, longshore drift. These conditions produce a complex pattern of ripple marks.

concordant date Radiometric dates for minerals by two or more methods that are in agreement; for example, indistinguishable dates based on different $\mathrm{U}$ and $\mathrm{Pb}$ isotopes.

cross-beds, cross-bedded, cross-bedding Beds inclined at an angle relative to the main bedding planes.

cross-lamination or cross-stratification Laminations (less than 1 $\mathrm{cm}$ thick) or stratification (no thickness restriction) in sandstone or siltstone that have cross-beds.

current-ripple lamination Laminations (less than $1 \mathrm{~cm}$ thick) that display asymmetric ripple marks.

debris-flow deposits Deposits emplaced as a flowing mass, consisting of rock fragments and finer sediment, of which more than half the particles are coarser than sand.

desert varnish A coating of iron and other oxides found on rock fragments after prolonged exposure in deserts.

diagenetic alteration Any physical, chemical, or biological changes in sediment after deposition.

dip Inclination of beds or faults measured from horizontal; perpendicular to strike.

dipslope A slope that is underlain by strata that dip in the same general direction and amount as the slope.

disconformably; disconformity Pertaining to a disconformity, an unconformity or break in deposition between parallel strata.

discordant A contact between an igneous intrusion and country rock that is not parallel to the foliation or bedding of the country rock.

discordant $\mathrm{U} / \mathrm{Pb}$ date Radiometric dates for a mineral by two or more methods that result in different dates for each method; for example, different dates for different $\mathrm{U}$ and $\mathrm{Pb}$ isotopes.

downlap depositional sequence A depositional sequence where each succeeding younger layer terminates against the base of the sequence, where progressively younger layers are found farther down the depositional gradient.

drape fold A fold that appears to have been draped over a fault in underlying rocks; such folds are more correctly called fault propagation folds.

euhedral Form of a crystal that has all its crystal faces.

even-parallel lamination Laminae that are nearly the same thickness and parallel in strata that contain sedimentary structures indicative of deposition by flowing wind or water.

expansive clay, soils, surficial deposits, or bedrock Clay, soil, surficial deposits, or bedrock units that contain smectitic clay that expands when wet and shrinks when dry.

fan-alluvium Alluvial deposits that form a fan-like shape.

fault propagation fold $\mathrm{A}$ fold that formed above the end of a fault.

flaggy Having the character of splitting into layers about 1 to 5 cm thick; similar to flagstone. 
grain-flow lamination Lamination inclined at the angle of repose on the leeward side of a dune and formed by sand avalanches.

gypsiferous Containing the mineral gypsum.

hanging wall The block of rock above a fault.

heterolithic Consisting of several rock types.

high-angle reverse fault $\mathrm{A}$ fault that dips more than $45^{\circ}$ and places older rocks above younger rocks.

hinge line Trace of the line that marks distinct changes in dip of strata.

horizontal lamination: Lamination that was deposited parallel to the earth's surface.

hornfels A fine-grained rock metamorphosed by heat from an igneous body.

hydrocompaction Any water-induced decrease in volume, causing subsidence of the ground surface. Hydrocompaction is produced by compaction of particles and (or) the dissolution and collapse of rock fragments or matrix material. This compaction results in surface or near-surface collapse.

inflection hinge line Trace of the line that marks the change from a concave-shaped fold to a convex-shaped fold.

intergranular flow Deformation of a rock caused by the flow of grains relative to one another.

kinematics In geology, the study of the direction that rock moves during faulting or folding.

lag gravel A coarse gravelly deposit left after wind or water removed finer sediments.

lamination, lamellae Layers of rock that are less than $1 \mathrm{~cm}$ thick.

lamprophyre A dark-colored intrusive rock that generally forms a dike and commonly contains phenocrysts of biotite, hornblende, and pyroxene in a fine-grained matrix.

laterally and vertically amalgamated scour surfaces Large-scale (few to tens of meters) scour surfaces that truncate each other in both horizontal and vertical directions. Commonly formed by braided and meandering rivers and migrating dunes.

lithic arkose An arkose that contains abundant rock fragments.

mass wasting Transport of soil or rock downslope by the force of gravity.

matrix The fine-grained material between coarser-grained clasts in a sediment or soil or between coarse crystals in an igneous or metamorphic rock.

matrix supported A sediment or soil in which there is sufficient matrix so that clasts within the matrix do not rest on one another and therefore the matrix supports the weight of overlying material.

migmatitic, migmatite, migmatization Having the character of a migmatite; a metamorphic rock that has been partially melted to form a feldspar- and quartz-rich granitic part and an unmelted residue rich in dark minerals such as biotite and hornblende; the process of forming a migmatite.

monoclinal fold, monocline A fold that forms an inclined plane of strata between areas of nearly horizontal strata.

normal fault A fault that generally dips $45^{\circ}$ to $90^{\circ}$ and places younger rocks over older rocks. normally graded Deposits that display clasts that gradually decrease in size upwards.

oscillation-flow ripple marks or oscillation ripple marks Symmetrical ripple marks caused by waves that washed grains back and forth.

packstone A sedimentary carbonate rock that has its grains arranged in a grain-supported framework.

paleosols Ancient buried soils or soil horizons.

palynological Pertaining to the science of the study of pollen, in this case fossil pollen.

parting lineations Lineations consisting of ridges or grooves formed parallel to current direction.

Pennsylvanian A period in the Paleozoic Era between 290 and 330(?) Ma.

Permian A period in the Paleozoic Era between about 240 and $290 \mathrm{Ma}$

piping Subsurface erosion of sand and finer material by percolating water, resulting in the formation of voids and conduits about a few centimeters to a few to several meters wide. These cavities can result in surface collapse.

plate margin Edge of relatively rigid slabs of the earth's lithosphere called plates.

porphyroblasts Coarse crystals in a fine-grained metamorphic rock matrix.

Precambrian The part of geologic time before the Paleozoic Era (greater than about 570 million years ago).

protolith The parent rock prior to that rock becoming metamorphosed.

ptygmatic fold Folds of granitic material in a metamorphic rock. Ptygmatic folds have shapes that are dissimilar to other structures in the rock.

$\mathrm{Rb} / \mathrm{Sr}$ isochron age The age of a geological event measured by the rubidium-strontium radiometric dating method.

rhizocretions Fossil roots.

ripple lamination, current-ripple lamination, wind-ripple lamination A sedimentary structure found in sand or silt that consists of ripple mark layers less than $1 \mathrm{~cm}$ thick.

ripple stratification A sedimentary feature in sand or silt that consists of layers of ripple marks.

schistosity Foliation in schist or other crystalline rock formed by the parallel alignment of platy minerals.

scour-and-fill structures and scour surfaces: Wavy bedding surfaces formed by erosion by water or wind.

sheetwash deposits Material transported and deposited on lowgradient slopes by water that is not confined to channels; considered to be a colluvial deposit in this report.

sigmoidal cross-bedding Cross-beds with S-shaped beds.

slickenlines Grooves and ridges formed as rock on one side of a fault grinds against rock on the other side.

smectite, smectitic clay A clay mineral that swells when wet and shrinks when dry; an expansive clay.

stock An igneous intrusion less than $100 \mathrm{~km}^{2}$ in area. 
strain The change in shape of rock during deformation caused by stress applied to the rock.

streaming lineations Faint streaks or lines on bedding surfaces produced by oriented elongate sand grains.

strike The compass direction of the horizontal trace of a planar feature such as bedding or a fault.

structural relief The amount of vertical offset on a stratigraphic horizon created by a folding or a faulting process.

structure contours Contours drawn on a specific stratigraphic horizon that show the shapes of structures.

subarkose A quartz-rich sedimentary rock that has $<25 \%$ feldspar, whereas an arkose has $>25 \%$ feldspar.

subhedral Form of a crystal that has only some of its crystal faces.

symmetric ripple lamination or ripple stratification Ripple lamination or ripple stratification that has a symmetric shape; implies wave action. tabular-planar cross-stratification A set of planar cross-beds or laminae that are truncated on top and bottom by parallel surfaces.

tabular-tangential cross-stratification A set of curved crossbeds or laminae that are truncated by parallel surfaces.

trough cross-stratification A set of curved cross-beds or laminae that are truncated on top and bottom by curved surfaces.

underfit streams Streams that appear too be to small to have eroded the valley in which they flow.

wackestone A mud-supported carbonate sedimentary rock containing more than $10 \%$ grains.

wedge-planar cross-stratification A set of planar cross-beds or laminae that are truncated on top and bottom by surfaces that are not parallel to one another.

wind-ripple lamination Layering in eolian sandstone that resembles "pinstripes" caused by migration of wind ripples across an interdune surface. 